SANDIA REPORT

SAND20009-2665

Unclassified Unlimited Release

Printed April 2009

Supersedes SAND 2008-2306

Dated April 2008

\title{
Sandia National Laboratories, California Environmental Management System Program Manual
}

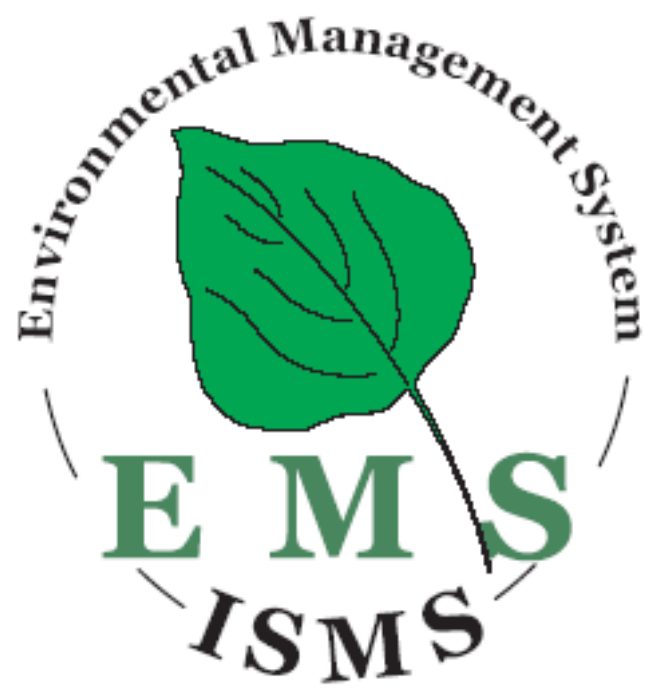

Prepared by

Environmental Management Department

Sandia National Laboratories

Livermore, California 94550

Sandia is a multiprogram laboratory operated by Sandia Corporation,

a Lockheed Martin Company, for the United States Department of Energy's

National Nuclear Security Administration under Contract DE-AC04-94AL85000.

Pending approval for public release; further dissemination unlimited. 
Issued by Sandia National Laboratories, operated for the United States Department of Energy by Sandia Corporation.

NOTICE: This report was prepared as an account of work sponsored by an agency of the United States Government. Neither the United States Government, nor any agency thereof, nor any of their employees, nor any of their contractors, subcontractors, or their employees, make any warranty, express or implied, or assume any legal liability or responsibility for the accuracy, completeness, or usefulness of any information, apparatus, product, or process disclosed, or represent that its use would not infringe privately owned rights. Reference herein to any specific commercial product, process, or service by trade name, trademark, manufacturer, or otherwise, does not necessarily constitute or imply its endorsement, recommendation, or favoring by the United States Government, any agency thereof, or any of their contractors or subcontractors. The views and opinions expressed herein do not necessarily state or reflect those of the United States Government, any agency thereof, or any of their contractors.

Printed in the United States of America. This report has been reproduced directly from the best available copy.

Available to DOE and DOE contractors from

U.S. Department of Energy

Office of Scientific and Technical Information

P.O. Box 62

Oak Ridge, TN 37831

$\begin{array}{ll}\text { Telephone: } & \text { (865) 576-8401 } \\ \text { Facsimile: } & \text { (865) 576-5728 }\end{array}$

E-Mail:_reports@adonis.osti.gov

Online ordering: http://www.doe.gov/bridge

Available to the public from

U.S. Department of Commerce

National Technical Information Service

5285 Port Royal Road

Springfield, VA 22161

Telephone: $\quad$ (800) 553-6847

Facsimile: (703) 605-6900

E-Mail:_orders@ntis.fedworld.gov

Online order: http://www.ntis.gov/ordering.htm
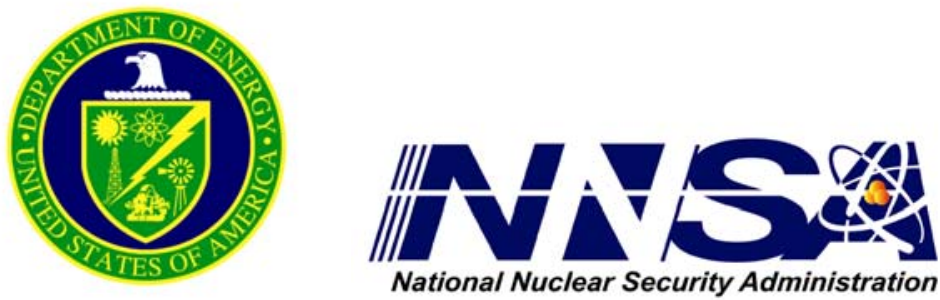
SAND2009-2665

Unclassified Unlimited Release

Printed April 2009

Supersedes SAND 2008-2306

Dated April 2008

\title{
Sandia National Laboratories, California Environmental Management System Program Manual
}

\author{
Environmental Management Department \\ Sandia National Laboratories, California \\ 7011 East Avenue \\ Livermore, CA 94550
}

\begin{abstract}
The Sandia National Laboratories, California (SNL/CA) Environmental Management System (EMS) Program Manual documents the elements of the site EMS Program. The SNL/CA EMS Program conforms to the International Standard on Environmental Management Systems, ISO 14001:2004and Department of Energy (DOE) Order 450.1.
\end{abstract}




\section{Contents}

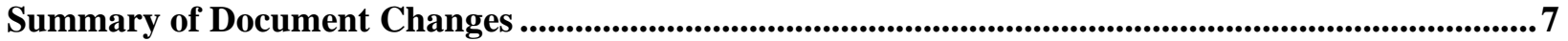

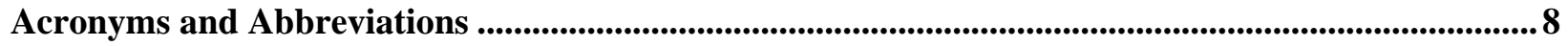

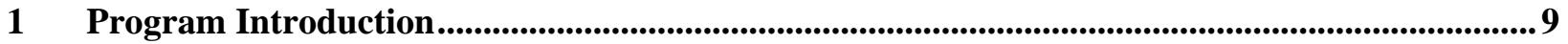

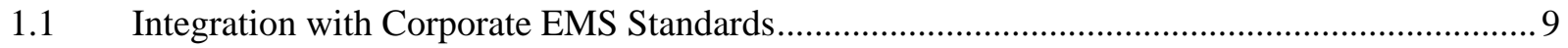

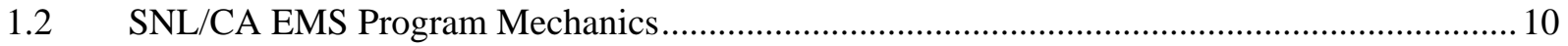

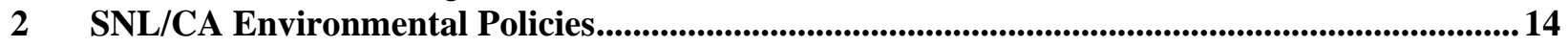

3 Structure, Responsibilities, and Authorities ................................................................................ 16

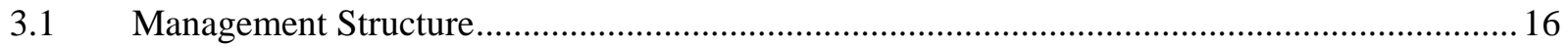

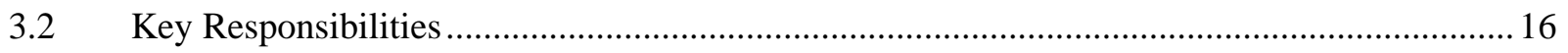

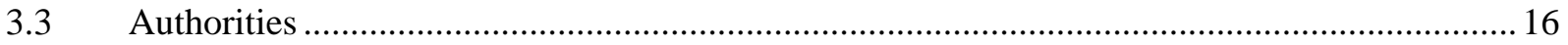

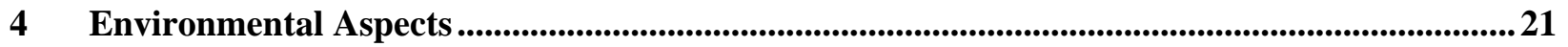

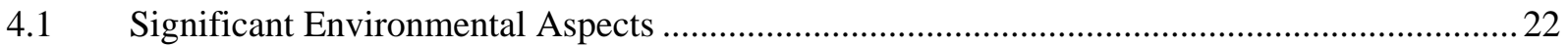

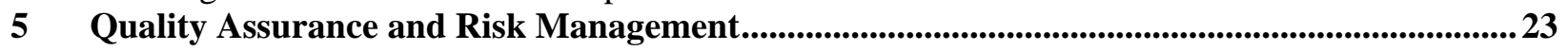

5.1 Identifying and Managing Risk to Environmental Management Personnel.............................. 24

5.2 Identifying and Managing Environmental Program Risk........................................................ 24

5.3 Identifying and Managing Risk Associated with Environmental Aspects ...............................24

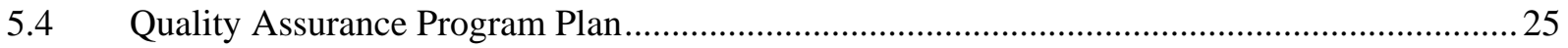

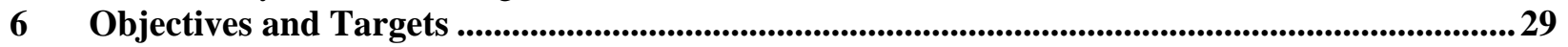

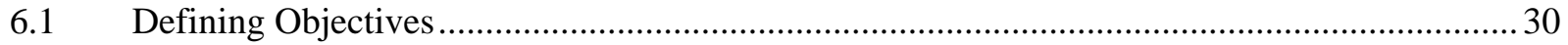

6.2 Defining Targets and Assigning Actions............................................................................... 31

$7 \quad$ Emergency Preparedness and Response ..............................................................................................39

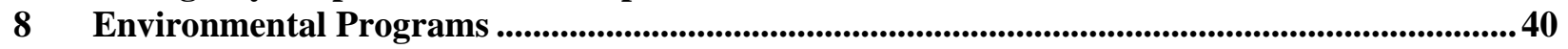

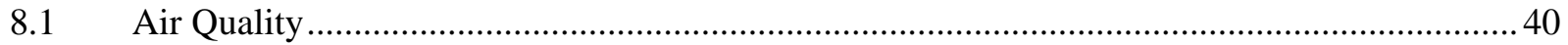

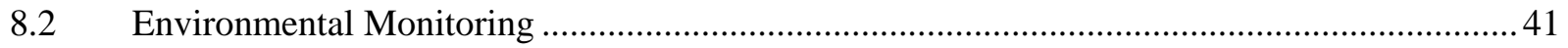

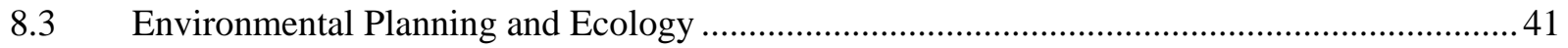

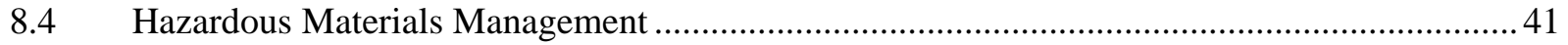

8.5 Pollution Prevention and Waste Minimization....................................................................... 42

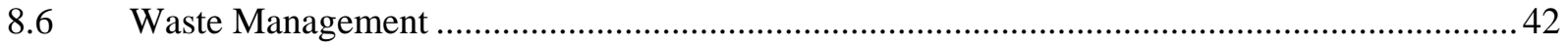

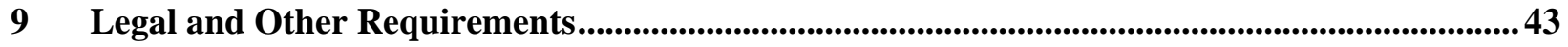

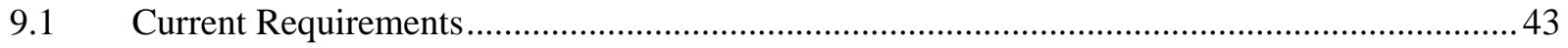

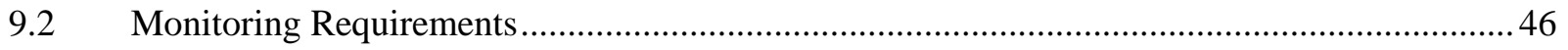

$9.3 \quad$ Recent Modifications to Requirements ................................................................................ 47

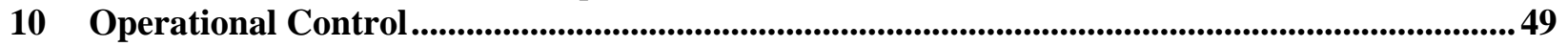

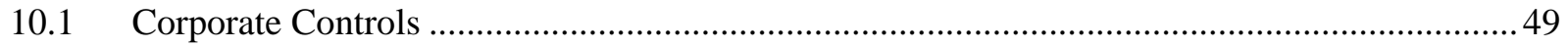

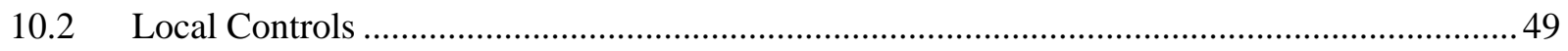

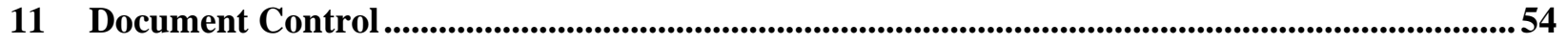




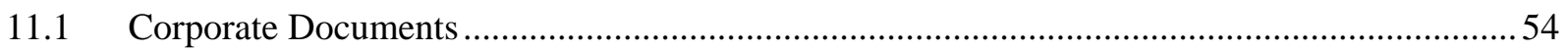

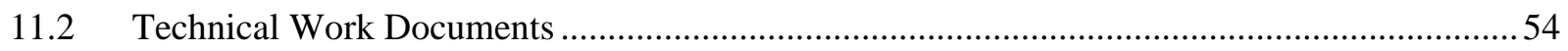

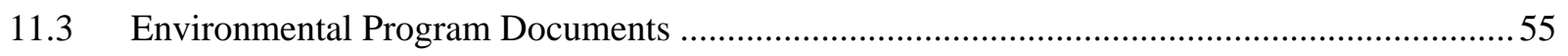

12 Competence, Training, and Awareness..........................................................................................56

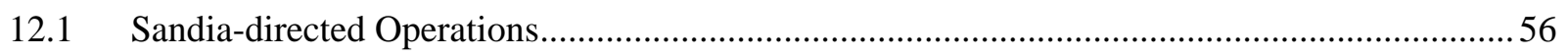

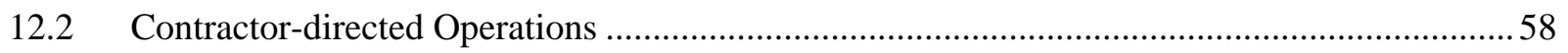

13 Environmental Monitoring and Measurement........................................................................................59

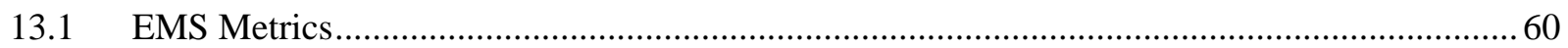

14 Evaluating Compliance with Environmental Requirements.......................................................61

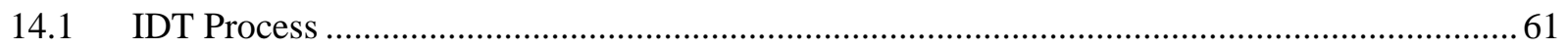

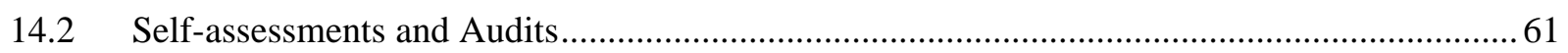

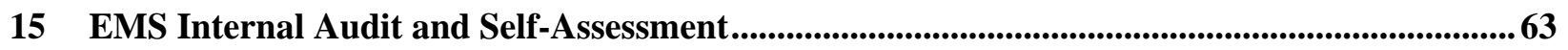

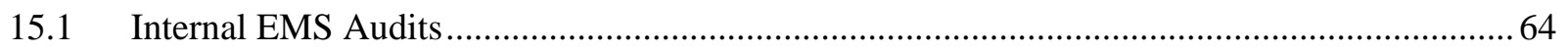

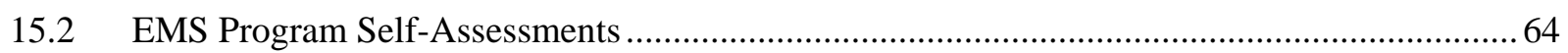

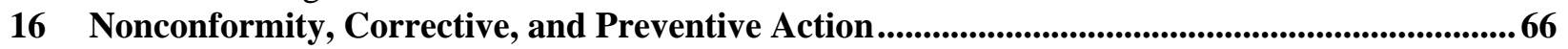

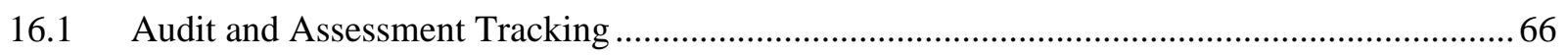

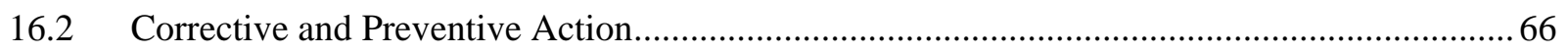

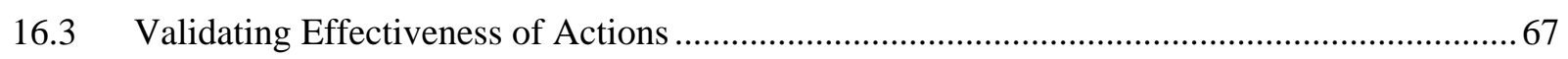

17 Management Review .............................................................................................................................68

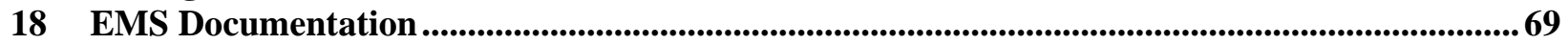

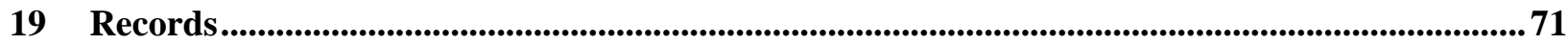

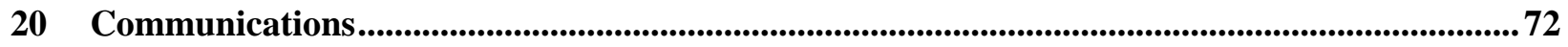

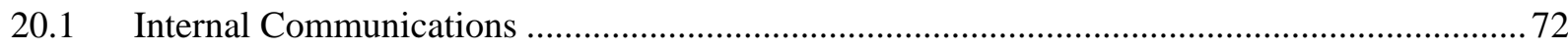

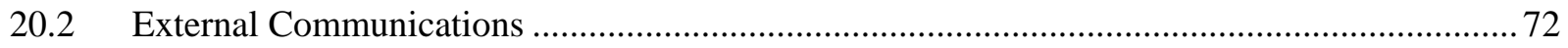

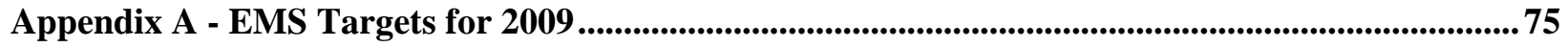

Appendix B - Environmental Program Reports ............................................................................................... 80

Appendix C - ES\&H Quality Assurance ..................................................................................................8. 81

Appendix D - SNL/CA Communication Plan Supplement ........................................................................ 105

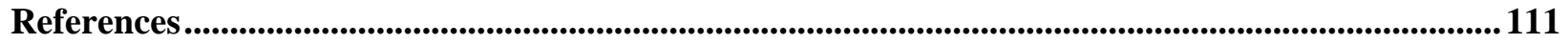




\section{Tables}

Table 1 Summary of Changes to EMS Program Manual, April 2009 .................................................. 7

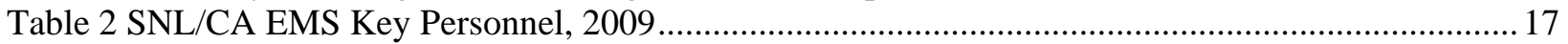

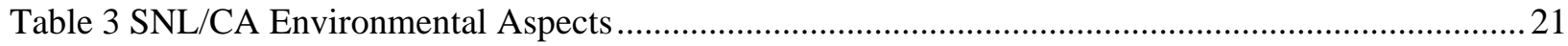

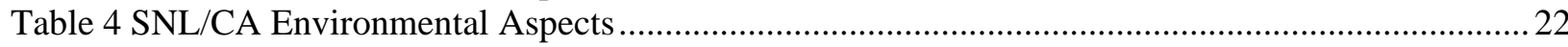

Table 5 Change in Significant Environmental Aspects Between 2008 and 2009..................................22

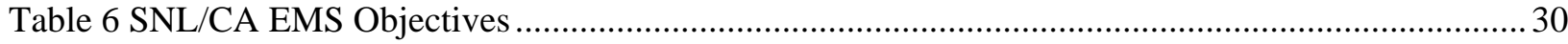

Table 7 Primary Environmental Requirements Associated with Environmental Aspects.........................43

Table 8 New and Modified Environmental Requirements, 2008/2009 .................................................. 47

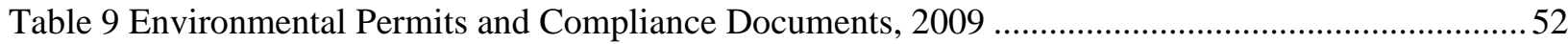

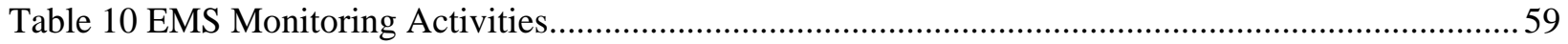

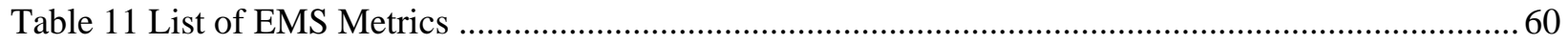

Table 12 SNL/CA Environmental Assessment and Audit Types ............................................................ 62

\section{Figures}

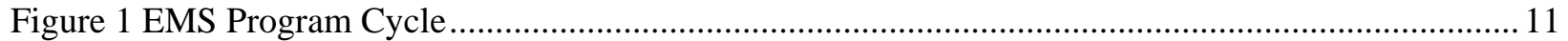

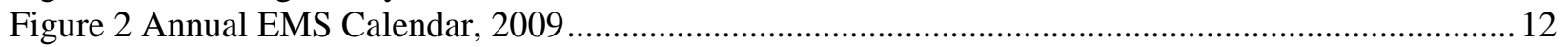

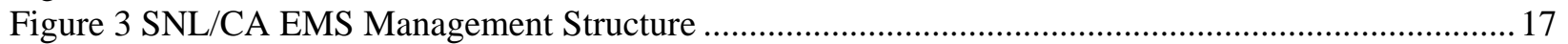

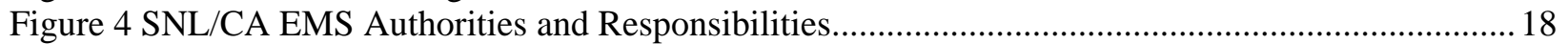

Figure 5 Environmental Management Department QA Process ...........................................................2

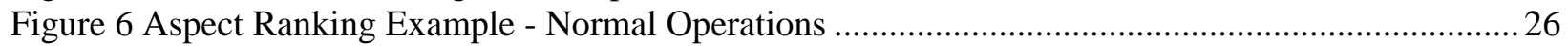

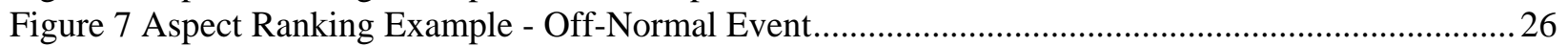

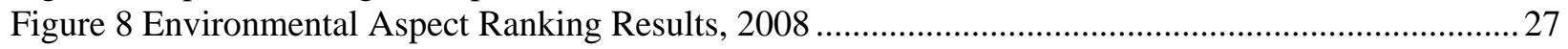

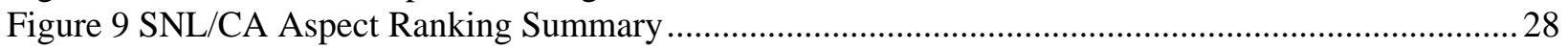

Figure 10 Cycle of Setting and Evaluating EMS Objectives and Targets ...........................................29

Figure 11 Water Discharges Objectives, Targets, and Actions .......................................................... 32

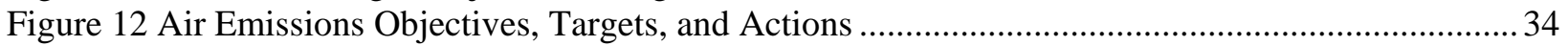

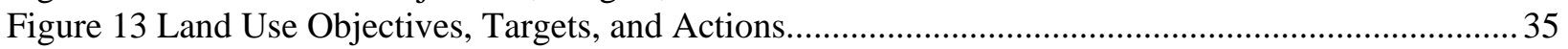

Figure 14 General Transportation Objectives, Targets, and Actions ...................................................... 37

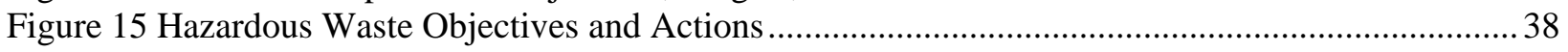

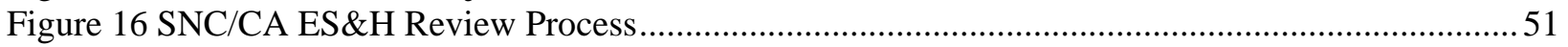

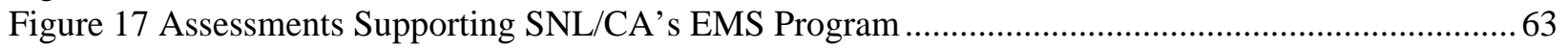

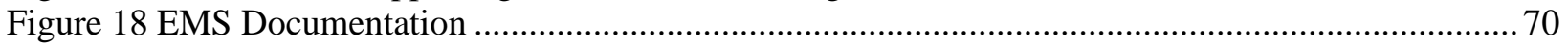

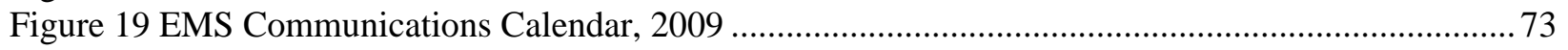

Figure 20 External Communication Decision Memo .............................................................................. 74 


\section{Summary of Document Changes}

Significant changes made to the April 2009 edition of the EMS Program Manual are marked with a sidebar within the document and summarized in Table 1.

Table 1 Summary of Changes to EMS Program Manual, April 2009

\begin{tabular}{|c|c|c|}
\hline Section & Page & Change \\
\hline Various & & $\begin{array}{l}\text { Updated references and summary of information throughout document to reflect change in } \\
\text { Corporate Business Rules System to new Corporate Policy System }\end{array}$ \\
\hline 1.1 & 9 & Updated to reflect changes in DOE Order 450.1A. \\
\hline 1.2 & 10 & $\begin{array}{l}\text { Added statement that EMS Manual information represents a point in time, with most up to } \\
\text { date information provided on the department website. }\end{array}$ \\
\hline 3.3 & 18 & Replaced Authorities and Responsibilities letter with updated version. \\
\hline 4.0 & 21 & Updated the significant aspects for 2009. \\
\hline 4.1 & 22 & Updated Table 4 with new ranking scores for 2009 \\
\hline 4.1 & 22 & Updated Table 5 with new significant aspects. \\
\hline 6.2 & $32-39$ & Replaced Fast Track action sheets for significant aspects. \\
\hline 10.1 & 49 & Updated and added footnote about upcoming changes in CBR system. \\
\hline 10.2 .1 & 50 & Added footnote about upcoming changes to work planning and control process. \\
\hline 10.2 .3 & 53 & Added Army Corp permit for Arroyo Improvements to Table 10 \\
\hline 10.2 .4 & 54 & Added text about new environmental specifications and environmental permit. \\
\hline 11.2 & 55 & Updated status of obsolete document control issues. \\
\hline 12.1 .1 & 57 & Added Work Authorization Form to training section \\
\hline 12.1.3 & 58 & Added information about ES\&H Visitor briefing card to visitor awareness section \\
\hline 15.1.1 & 65 & Updated 2008 audit information \\
\hline 15.2 .1 & 65 & Updated 2008 assessment information \\
\hline 16.1 & 67 & $\begin{array}{l}\text { Updated audit and assessment tracking with new information from updated assessment } \\
\text { procedure }\end{array}$ \\
\hline 16.2 & 67 & Updated corrective and preventive action process to match procedure. \\
\hline 16.3 & 68 & Updated validation process to match procedure. \\
\hline 17 & 69 & Updated with results of 2008 management reviews. \\
\hline 19 & 72 & Added Web File Share electronic records option \\
\hline 20 & 74 & Updated communications calendar \\
\hline
\end{tabular}




\section{Acronyms and Abbreviations}

BAAQMD

CARB

CBR System

CEDT System

CFR

CPR

CPS

CPSR

CWRCB

DOE

EMS

EP Rep

EPCRA

ES\&H

IDT

ISMS

ISO

$\mathrm{M} \& \mathrm{O}$ Contract

MSDS

NEPA

PHS

QA

QAPP

RCRA

SHEAC

SME

SNL

SNL/CA

$\mathrm{SNL} / \mathrm{NM}$

USC
Bay Area Air Quality Management District

California Air Resources Board

Corporate Business Rules System

Corporate Education, Development, and Training System

Code of Federal Regulations

corporate process requirement

corporate policy statement

corporate policy statement requirement

California Water Resources Control Board

Department of Energy

Environmental Management System

Environmental Programs Representative

Emergency Planning and Community Right to Know Act

environment, safety, and health

Interdisciplinary Team

Integrated Safety Management System

International Organization for Standardization

management and operating contract

material safety data sheet

National Environmental Policy Act

primary hazard screening

quality assurance

Quality Assurance Program Plan

Resource Conservation and Recovery Act

Safety, Health \& Environment Action Committee

subject matter expert

Sandia National Laboratories

Sandia National Laboratories, California

Sandia National Laboratories, New Mexico

United States Code 


\section{Program Introduction}

Sandia National Laboratories, California (SNL/CA) has maintained functional environmental programs to assist with regulatory compliance for more than 30 years. During 2005, these existing programs were rolled into a formal environmental management system (EMS) that expands beyond the traditional compliance focus to managing and improving environmental performance and stewardship practices for all site activities. An EMS is a set of inter-related elements that represent a continuing cycle of planning, implementing, evaluating, and improving processes and actions undertaken to achieve environmental policy and goals. The SNL/CA EMS Program conforms to the International Standard for Environmental Management Systems, ISO 14001:2004 (ISO 2004). The site received ISO 14001 certification in September 2006.

SNL/CA's EMS Program is applicable to the Sandia, Livermore site only. Although SNL/CA operates as one organizational division of the overall Sandia National Laboratories, the EMS Program is site-specific, with site-specific objectives and targets. SNL/CA (Division 8000) benefits from the organizational structure as it provides corporate level policies, procedures, and standards, and established processes that connect to and support elements of the SNL/CA EMS Program. Additionally, SNL/CA's EMS Program benefits from two corporate functional programs (Facilities Energy Management and Fleet Services Environmental programs) that maintain responsibility for energy management and fleet services for all Sandia locations. Each EMS element is further enhanced with site-specific processes and standards.

Division 8000 has several groups operating at Sandia National Laboratories, New Mexico (SNL/NM). Although these groups, from an organizational perspective, are part of Division 8000, they are managed locally and fall under the environmental requirements specific to their New Mexico location. The New Mexico groups in Division 8000 follow the corporate EMS Program for New Mexico operations.

\subsection{Integration with Corporate EMS Standards}

On June 4, 2008, the Department of Energy (DOE) issued a revised DOE Order 450.1A, Environmental Protection Program. Order 450.1A outlines the basic strategy for environmental compliance at DOE facilities. It became effective for all Sandia National Laboratories (SNL) facilities on September 3, 2008 through incorporation into the Sandia management and operating contract. The objectives of Order 450.1A are to implement sound environmental stewardship practices, and to meet or exceed compliance with environmental, public health, and resource protection laws, regulations, and DOE requirements (DOE 2008). The order requires DOE sites to meet these objectives through an environmental management system (EMS) that follows the ISO 14001 framework (DOE 2008). To meet this new requirement, Sandia's corporate EMS program has been modified to the ISO standard and is scheduled for a certification audit in June 2009. 
Under the corporate EMS umbrella, each SNL Division implements an EMS program tailored to the characteristics and operations of that division. Because the SNL/CA EMS Program conforms to the ISO 14001 Standard, it already meets the requirements of DOE Order 450.1A as well as the updated corporate program.

\subsection{SNL/CA EMS Program Mechanics}

SNL/CA prepared the Sandia National Laboratories, California Environmental Management System Program Manual (EMS Manual) to document and provide a roadmap to its EMS Program. Annually, the SNL/CA EMS Core Team updates the EMS Manual to document the aspects/impacts of current operations, the goals and objectives that respond to these impacts and the EMS changes and improvements that occurred during the year. The EMS Manual represents a point in time. Updated information about the EMS program is added to the Environmental Management Department website. Consequently, the most up-to-date information is typically found on Sandia's website.

The SNL/CA EMS Program encompasses an annual cycle of planning, implementing, assessing, and improving operations in support of site-specific environmental goals. The EMS Program cycle is presented in Figure 1. As shown, the EMS cycle aligns with the budget cycle so that investment and resource requirements can be requested for the next budget year. To provide further detail of the timing of EMS actions throughout the year, an annual EMS calendar is maintained and included as Figure 2. 


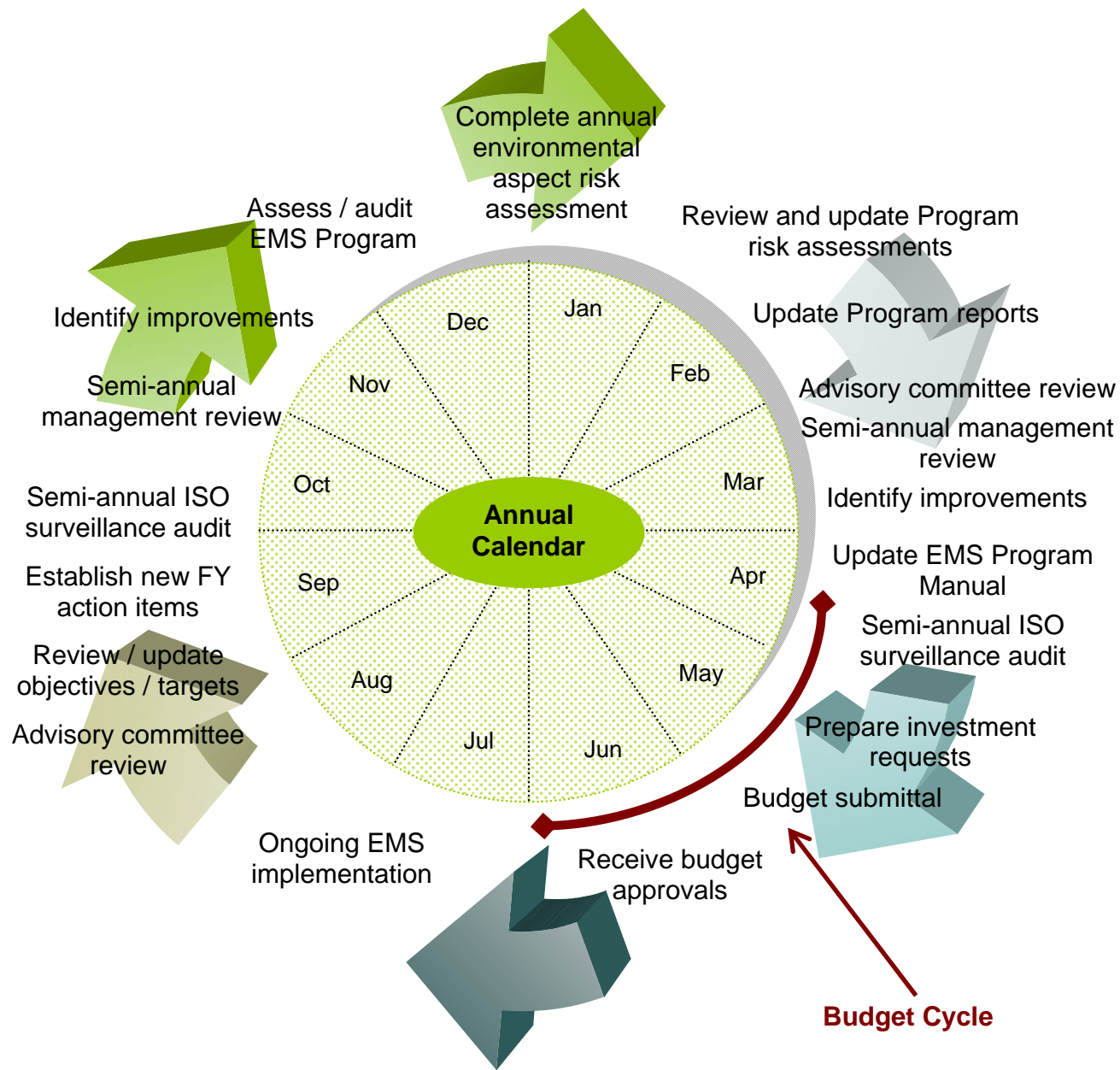

Figure 1 EMS Program Cycle 
EMS Program Manual

April 2009

Figure 2 Annual EMS Calendar, 2009

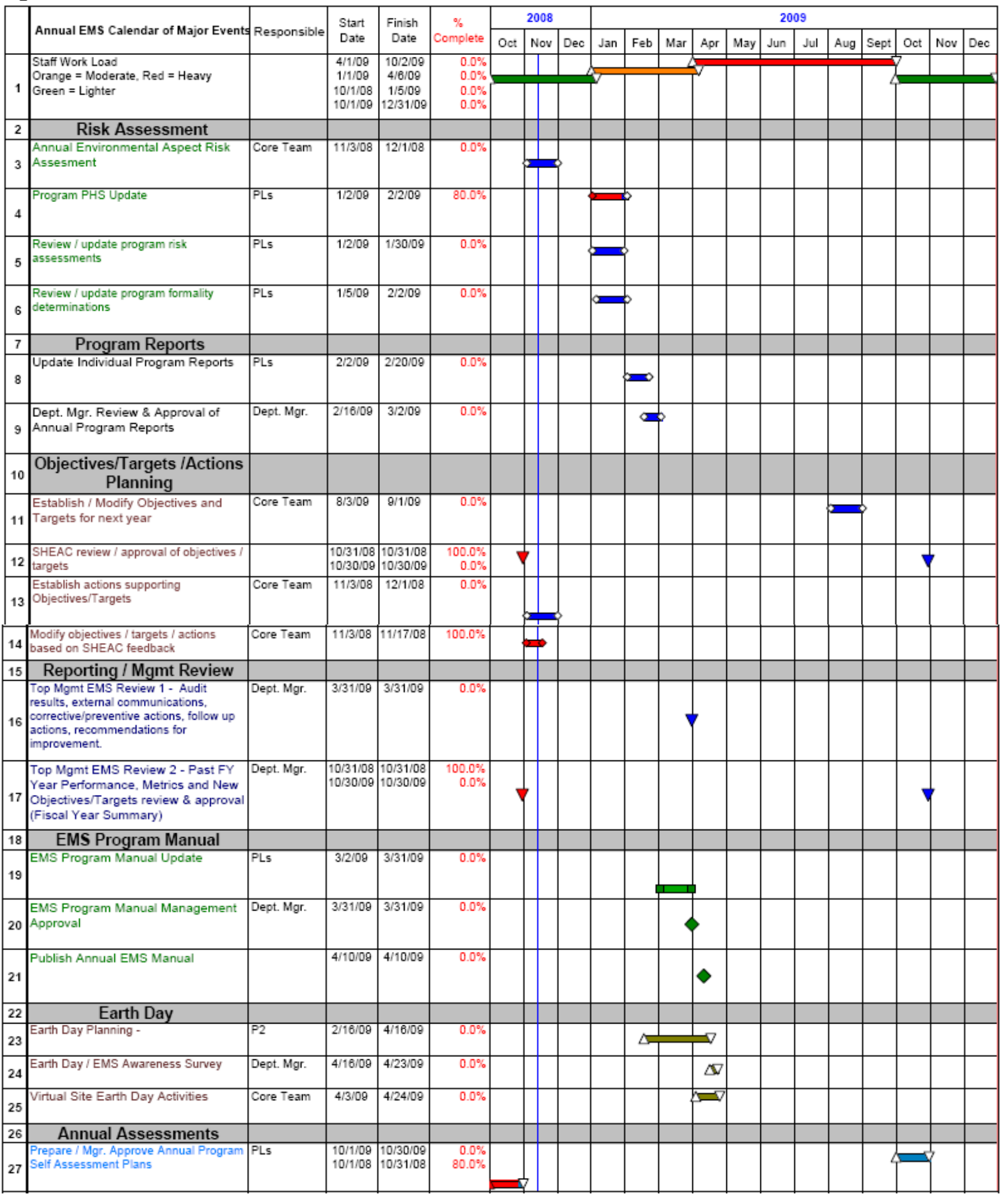


EMS Program Manual

April 2009

\begin{tabular}{|c|c|c|c|c|c|c|c|c|c|c|c|c|c|c|c|c|c|c|c|c|}
\hline 28 & $\begin{array}{l}\text { Perform Program Self and Line } \\
\text { Assessments }\end{array}$ & PLS & \begin{tabular}{|l|}
$11 / 2 / 09$ \\
$11 / 3 / 08$ \\
\end{tabular} & \begin{tabular}{|l|}
$12 / 24 / 00$ \\
$12 / 22 / 08$
\end{tabular} & $\begin{array}{r}0.0 \% \\
25.0 \% \\
\end{array}$ & & & & & & & & & & & & & & & $\rightarrow$ \\
\hline 29 & $\begin{array}{l}\text { Env. Manager Annual EMS Self } \\
\text { Assessment }\end{array}$ & Dept. Mgr. & \begin{tabular}{|l|}
$11 / 2 / 09$ \\
$11 / 3 / 08$
\end{tabular} & $\begin{array}{l}12 / 17 / 08 \\
12 / 15 / 08 \\
\end{array}$ & $\begin{array}{l}0.0 \% \\
0.0 \%\end{array}$ & & & & & & & & & & & & & & & $\nabla$ \\
\hline 30 & ISO Certification Actions & & & & & & & & & & & & & & & & & & & \\
\hline 31 & Surveilence Audit \#5 & Core Team & 6/8/09 & $6 / 8 / 09$ & $0.0 \%$ & & & & & & & & & B & & & & & & \\
\hline 32 & Recertification Audt \#1 & Core Team & $6 / 8 / 09$ & $6 / 11109$ & $0.0 \%$ & & & & & & & & & 口 & & & & & & \\
\hline 33 & Misc. EMS Actions & & & & & & & & & & & & & & & & & & & \\
\hline 34 & $\begin{array}{l}\text { Determine groups /individuals that have } \\
\text { exhibited exemplary environmental } \\
\text { pherformance for the year. }\end{array}$ & Core Team & $9 / 30 / 09$ & 9/30/09 & $0.0 \%$ & & & & & & & & & & & & & & & \\
\hline 35 & $\begin{array}{l}\text { Update communications calendar for } \\
\mathrm{CY}\end{array}$ & Dept. Mgr. & $1 / 30 / 09$ & $1 / 30 / 08$ & $0.0 \%$ & & & & & & & & & & & & & & & \\
\hline 36 & Update Documents Spreadsheet & Dept. Mgr. & \begin{tabular}{|c|}
$10 / 1 / 09$ \\
$10 / 10 / 08$ \\
\end{tabular} & \begin{tabular}{|l|}
$10 / 20 / 09$ \\
$10 / 31 / 08$ \\
\end{tabular} & $\begin{array}{l}0.0 \% \\
0.0 \%\end{array}$ & $\Rightarrow$ & & & & & & & & & & & & $\Leftrightarrow$ & & \\
\hline 37 & Annual VP Delegation of Authority & Dept. Mgr. & \begin{tabular}{|l|}
$10 / 30 / 09$ \\
$10 / 31 / 08$ \\
\end{tabular} & \begin{tabular}{|l|}
$10 / 30 / 08$ \\
$10 / 31 / 08$
\end{tabular} & $\begin{array}{l}0.0 \% \\
0.0 \% \\
\end{array}$ & & 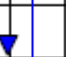 & & & & & & & & & & & & & \\
\hline 38 & ASER Preparation - Draft Submission & Larsen & 1/2/09 & $3 / 11 / 09$ & $0.0 \%$ & & & & & & $\Rightarrow$ & & & & & & & & & \\
\hline 39 & \begin{tabular}{|l|} 
ASER Submission \\
(Calendar Year Summary)
\end{tabular} & Larsen & 6/1/109 & $6 / 1 / 08$ & $0.0 \%$ & & & & & & & & & 个 & & & & & & \\
\hline 40 & Publish and distribute ASER & Larsen & 6/2/09 & $8 / 3 / 09$ & $0.0 \%$ & & & & & & & & & $g=$ & & 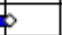 & & & & \\
\hline 41 & $\begin{array}{l}\text { Review web-based EMS Roadmap and } \\
\text { make corrections as appropriate. }\end{array}$ & & $\begin{array}{l}3 / 2 / 09 \\
9 / 1 / 09 \\
\end{array}$ & $\begin{array}{l}3 / 30 / 09 \\
10 / 1109 \\
\end{array}$ & $\begin{array}{l}0.0 \% \\
0.0 \% \\
\end{array}$ & & & & & & & & & & & & & & & \\
\hline 42 & Advisory & & & & & & & & & & & & & & & & & & & \\
\hline 43 & Advisory Committee Review & Dept. Mgr. & \begin{tabular}{|l|}
$3 / 13 / 09$ \\
9/30/09
\end{tabular} & $\begin{array}{l}3 / 13 / 02 \\
9 / 30 / 09\end{array}$ & $\begin{array}{l}0.0 \% \\
0.0 \%\end{array}$ & & & & & & $\boldsymbol{\nabla}$ & & & & & & & & & \\
\hline & & & & & & Oct & Nov & Dec & Jan & Feb & Mar & Apr & May & Jun & Jul & Aug & Sept & Oct & Nov & Dec \\
\hline
\end{tabular}




\section{SNL/CA Environmental Policies}

SNL/CA follows corporate and site-specific environmental policies that are combined with broader environment, safety, and health (ES\&H) requirements. The Sandia corporate policy (CPSR400.1) (SNL 2007a) is to protect and preserve the environment, and to ensure the safety and health of its Members of the Workforce by providing a place of employment that is free from recognized hazards that have the potential to cause physical harm to workers. Principles

outlined in the corporate policy related to environmental management include employee accountability for minimizing impact on the environment and the belief that environmental incidents are preventable and unacceptable. Sandia's ES\&H performance objectives also include creating a work environment that strives for zero environmental incidents and zero operations fines, violations, or penalties.

In addition, the SNL/CA Vice President re-issued a Division 8000 ES\&H standard of performance statement in January 2007. The statement reinforces individual accountability, environmental stewardship, and regulatory compliance - the basic elements of the corporate ES\&H policy (SNL 2007a). The statement stresses the need to move beyond compliance requirements to nurture a positive ES\&H culture at all levels of the workforce.

\section{Annually, the SNL/CA EMS Core}

Team reviews the ES\&H standard of performance statement to ensure that it remains aligned with the site vision and the corporate ES\&H policy. This review is executed as part of the internal EMS program audit. If needed, the EMS team presents recommendations for revisions to site management during the management review process described in Chapter 17.

\section{SNL/CA ES\&H Standard of Performance}

SNL/CA is firmly committed to meeting all corporate and regulatory ES\&H policies and requirements that apply to its operations. The application of compliant ES\&H principles and practices is considered a fundamental element of everyone's work assignment.

In this regard, SNL/CA commits to:

- Nurture a safety and health conscious work ethic and culture. We will all assume responsibility for creating and maintaining a worksite, as well as performing our work, in a manner that respects and supports the safety and health of every individual. SNL/CA believes that all accidents are preventable. We will all strive to create a workplace that is free of accidents and injuries.

- Be a responsible steward of the environmental resources in our care. We will integrate environmental risk assessment, planning and impact mitigation into every aspect of our work. SNL/CA programs, operations, processes, and facilities will be planned and managed such that they support environmental objectives and targets to minimize the creation of waste, pollution, and adverse impact on the public and the environment. SNL/CA will remain committed to an efficient and effective Environmental Management System as part of the laboratory's Integrated Safety Management System.

- Comply with all applicable laws, regulations and permits. Compliance with the letter and the spirit of ES\&H laws and regulations is viewed as the minimum acceptable standard. When necessary and appropriate we will go beyond legal mandates in order to implement more effective approaches and to nurture a positive and learning ES\&H culture. SNL/CA is committed to continual improvement in all aspects of our environment, safety, and health performance and commits to establish performance indicators to guide these efforts and measure our progress. 
The Standard of Performance Statement resides on the SNL/CA ES\&H website at http://surf.ran.sandia.gov/centers/8500/esh/CA-EnvMgmt/policy and the Sandia external website at http://public.ca.sandia.gov/casite/about/community/environmental_mgt.php. It was also made into posters and distributed to the site management team for display in their respective organizations (at their discretion). 


\section{Structure, Responsibilities, and Authorities}

\subsection{Management Structure}

The management structure for SNL/CA's EMS Program is depicted in Figure 3. As shown, the EMS Program is implemented through the Environmental Management Department under the Site Operations Center. Site Operations is one of six centers at SNL/CA reporting to the SNL/CA (Division 8000) Vice President. The site Vice President oversees the Safety, Health, \& Environment Action Committee (SHEAC) comprised of the site vice president and center directors. SHEAC provides leadership and strategic management oversight of ES\&H for Division 8000, and validates and approves the site EMS Program. The SNL/CA EMS Core Team manages day-to-day implementation and maintenance of the EMS Program. An advisory committee consisting of representatives from various functional areas also supports the EMS Program.

\subsection{Key Responsibilities}

SNL/CA personnel with key responsibility for the EMS Program include the site Vice President, the Director of Site Operations, the Level II Manager for ES\&H, Facilities, and Security, the Manager for the Environmental Management Department, and the environmental functional program leads. The site Vice President holds overall responsibility for the success of the SNL/CA EMS Program and establishes the ES\&H standard of performance for all site operations. The Director, Level II Manager, and Department Manager are responsible for providing the appropriate resources to implement and maintain the EMS, functional programs, and site infrastructure to support EMS objectives and targets. The Department Manager also serves as the designated management representative for the EMS. The functional program leads are responsible for day-to-day management of EMS elements and for assisting the site workforce in meeting established objectives and targets. The Environmental Programs Representative serves as an environmental liaison to the workforce. SNL/CA personnel assigned to each job function are listed in Table 2.

\subsection{Authorities}

EMS authorities at SNL/CA are defined in an internal memorandum issued by the Division 8000 Vice President on November 13, 2008. Authorities are defined for all levels of the workforce from the site VP, directors, and managers, to the basic worker. A copy of the authorities memorandum is provided in Figure 4. 


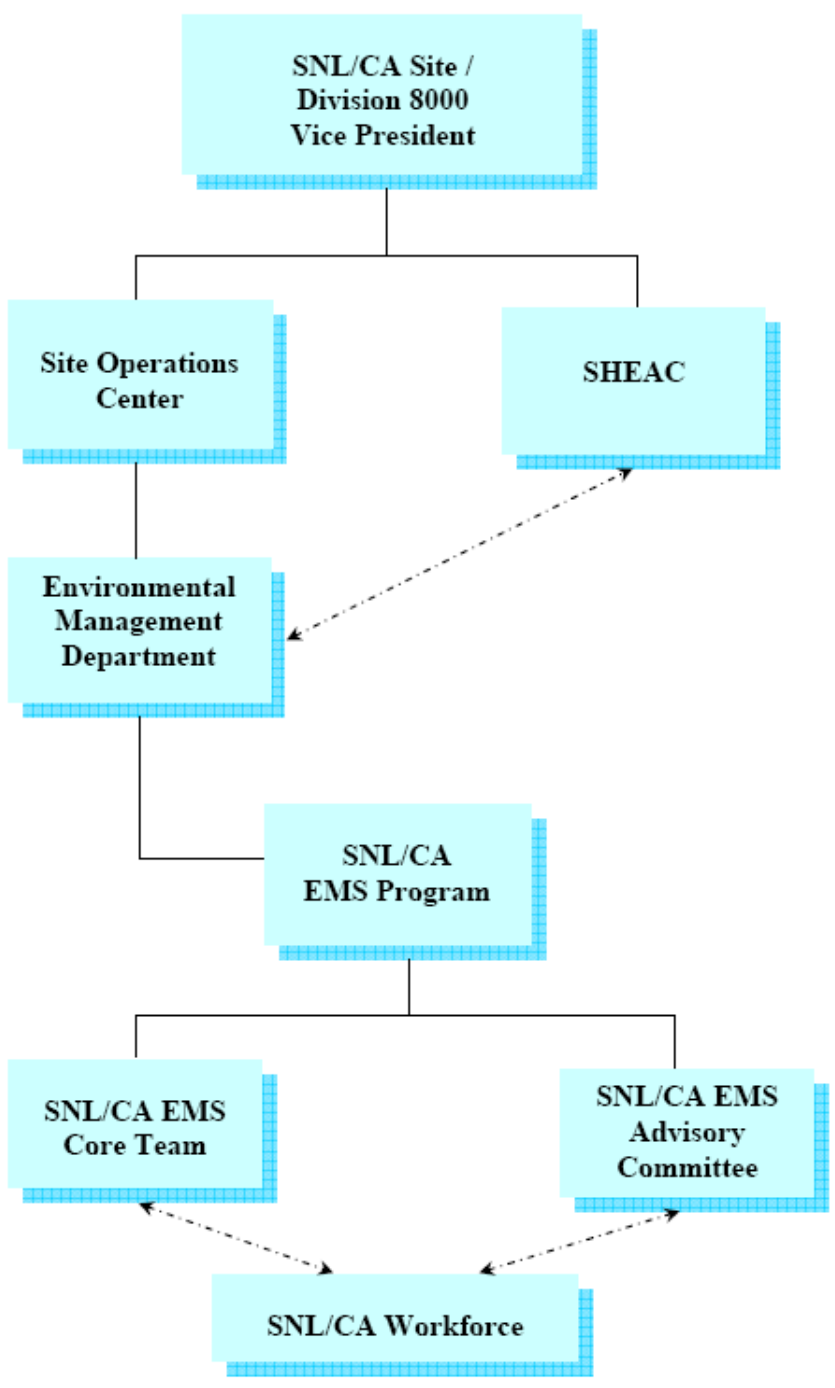

Figure 3 SNL/CA EMS Management Structure

Table 2 SNL/CA EMS Key Personnel, 2009

\begin{tabular}{ll}
\hline Job Function or Title & Name \\
\hline & Paul Hommert (through June \\
Vice President, SNL/CA (Division 8000) & Rick Stulen (after June 09) \\
\hline Director, Site Operations & Pat Smith \\
\hline Level II Manager, ES\&H, Facilities, and Security & Ed Cull \\
\hline Department Manager, Environmental Management & Gary Shamber \\
\hline Designated Management Representative & Gary Shamber \\
\hline Environmental Programs Representative & Deanna Dicker \\
\hline Functional Program Leads: & \\
\hline Air Quality & Leslee Gardizi \\
\hline Environmental Monitoring and Restoration & Robert Holland \\
\hline Environmental Planning and Ecology & Barbara Larsen \\
\hline Hazardous Materials Management & Mark Brynildson \\
\hline Pollution Prevention and Waste Minimization & Janet Harris / Laurie Farren \\
\hline Waste Management & Mark Brynildson \\
\hline
\end{tabular}


Figure 4 SNL/CA EMS Authorities and Responsibilities

\section{团 Sandia National laboratories \\ Operated for the U.S. Department of Energy by \\ Sandia Corporation}

Livermore, CA 94551-0969

dare: Nov 13, 2008

to. Division $8000 /$ CA Site Members of the Workforce

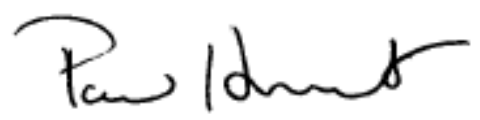

tram: Paul Hommert, 8000, MS 9001

subject: Personal Authorities and Responsibilities regarding the SNL/CA Environmental Management System (EMS).

SNL/CA's Environmental Management System (EMS) is ISO14001:2004 certified. Certification requires that roles, responsibilities and authorities of persons working for or on behalf of the EMS be identified and approved. This memorandum constitutes this identification and approval by me. Please direct questions and concerns to the site EMS Management Representative, Gary Shamber, 4-2237.

\begin{tabular}{|l|l|}
\hline Vice President & $\circ \begin{array}{l}\text { Endorse and communicate the site } \\
\text { environmental standards of performance, } \\
\text { Set the tone and priority, and demonstrate full } \\
\text { commitment and support to the EMS and the } \\
\text { maintenance of ISOl } 4001 \text { certification, }\end{array}$ \\
& $\begin{array}{l}\text { Communicate the site's environmental } \\
\text { stewardship commitment to the local } \\
\text { community as opportunities to do so are } \\
\text { presented, } \\
\text { Provide annual delegation of authority for the } \\
\text { generation and submission of required } \\
\text { environmental reports, documents and } \\
\text { payment of fees. }\end{array}$ \\
\hline Director, Site Operations & $\circ \begin{array}{l}\text { Ensure adequate budget and resources for } \\
\text { EMS and the maintenance of the site } \\
\text { ISO14001 certification. }\end{array}$ \\
\hline $\begin{array}{l}\text { Division ES\&H Committee (SHEAC) (VP and } \\
\text { site Directors) }\end{array}$ & $\circ \begin{array}{l}\text { Review and approve proposed changes to } \\
\text { environmental policies or practices, }\end{array}$ \\
& $\circ \begin{array}{l}\text { Promote site awareness of environmental } \\
\text { policies and issues, }\end{array}$ \\
\hline $\begin{array}{l}\text { Champion a culture of environmental } \\
\text { stewardship as the way of conducting } \\
\text { business, } \\
\text { Approve site environmental goals, objectives }\end{array}$ \\
\hline
\end{tabular}




\begin{tabular}{|c|c|c|}
\hline & $\circ$ & $\begin{array}{l}\text { and targets, } \\
\text { Review environmental performance and issues } \\
\text { as required by ISO14001. }\end{array}$ \\
\hline EMS Management Representative & $\begin{array}{l}\circ \\
\circ \\
\circ \\
\circ\end{array}$ & $\begin{array}{l}\text { Ensure that an EMS is established, } \\
\text { implemented and maintained in accordance } \\
\text { with ISO14001, } \\
\text { Annually develop goals, objectives and targets } \\
\text { (reflecting site operations) aimed at reducing } \\
\text { environmental risks and impacts, } \\
\text { Annually report to site senior management } \\
\text { (SHEAC) on the performance and status of the } \\
\text { site EMS, } \\
\text { Recommend improvements of the site EMS. }\end{array}$ \\
\hline Manager, Environmental Management & $\circ$ & $\begin{array}{l}\text { Provide effective management of site } \\
\text { environmental programs, } \\
\text { Direct the environmental programs towards } \\
\text { meeting approved environmental goals, } \\
\text { objectives and targets. }\end{array}$ \\
\hline Procurement \& Purchasing Management & o & $\begin{array}{l}\text { Develop, maintain and execute processes and } \\
\text { procedures that support the procurement of } \\
\text { environmentally supportive (friendly) products } \\
\text { and services. }\end{array}$ \\
\hline Facilities Management & 0 & $\begin{array}{l}\text { Develop, maintain and execute processes and } \\
\text { procedures that support sustainable design } \\
\text { principles in facilities design, construction and } \\
\text { operations, } \\
\text { Develop, execute and maintain processes and } \\
\text { procedures that minimize the environmental } \\
\text { impacts of site and building construction and } \\
\text { maintenance. }\end{array}$ \\
\hline All Managers & $\circ$ & $\begin{array}{l}\text { Assure operations remain compliant with all } \\
\text { applicable environmental laws and } \\
\text { requirements, } \\
\text { Develop, execute and maintain processes and } \\
\text { procedures that minimize the production of } \\
\text { waste (all types), minimize air and water } \\
\text { pollutant emissions, promote water and energy } \\
\text { conservation and encourage procurement of } \\
\text { environmentally friendly products and } \\
\text { services, } \\
\text { Promote environmental awareness and best } \\
\text { practices. }\end{array}$ \\
\hline
\end{tabular}




\begin{tabular}{|l|l|}
\hline $\begin{array}{l}\text { Subject Matter Experts, ES\&H Coordinators, and } \\
\text { Environmental Programs Representative }\end{array}$ & $\begin{array}{l}\text { Assist members of the workforce in the } \\
\text { environmental planning, analysis and } \\
\text { execution of projects and activities to reduce } \\
\text { environmental impacts and risks. }\end{array}$ \\
\hline Members of the Workforce & $\begin{array}{l}\text { Comply with all environmental laws and } \\
\text { requirements, } \\
\text { Perform all operations and activities such that } \\
\text { they support site environmental goals, } \\
\text { objectives and targets, } \\
\text { Refrain from participating in operations or } \\
\text { activities that are non-compliant with } \\
\text { environmental laws and requirements, } \\
\text { Report all environmentally non-compliant } \\
\text { operations or activities, }\end{array}$ \\
\hline $\begin{array}{l}\text { Suspend operations and activities they observe } \\
\text { to be non-compliant with environmental laws } \\
\text { and requirements. }\end{array}$ \\
\hline
\end{tabular}

Distribution:

SNL/CA Members of the Workforce 


\section{Environmental Aspects}

An environmental aspect is an element of an organization's activities, products, or services that can interact with the environment. Simply put, an environmental aspect is a pathway for an environmental impact, either beneficial or adverse. For 2009, the EMS Core Team reviewed the previous environmental aspects identified for SNL/CA to reaffirm their applicability to current operations. One aspect, universal waste, a subset of hazardous waste, was combined with the hazardous waste aspect. All others were reaffirmed as applicable to current operations. SNL/CA's environmental aspects are presented in Table 3 along with the specific site activities that correspond to each aspect.

Table 3 SNL/CA Environmental Aspects

\begin{tabular}{|c|c|}
\hline Environmental Aspect & Site activity \\
\hline Water discharges & $\begin{array}{l}\text { office operations, medical operations, laboratory and test activities, } \\
\text { facilities construction and deconstruction, exterior maintenance and } \\
\text { operations, building maintenance and operations, general environmental } \\
\text { operations }\end{array}$ \\
\hline Air emissions & $\begin{array}{l}\text { laboratory and test activities, facilities construction and deconstruction, } \\
\text { exterior maintenance and operations, building maintenance and operations, } \\
\text { onsite receiving and transportation, offsite transportation }\end{array}$ \\
\hline Land use & $\begin{array}{l}\text { general environmental operations, facilities construction and } \\
\text { deconstruction, exterior maintenance and operations }\end{array}$ \\
\hline Material procurement and use & $\begin{array}{l}\text { office operations, medical operations, laboratory and test activities, } \\
\text { facilities construction and deconstruction, exterior maintenance and } \\
\text { operations, building maintenance and operations, general environmental } \\
\text { operations }\end{array}$ \\
\hline Hazardous materials & $\begin{array}{l}\text { medical operations, laboratory and test activities, facilities construction and } \\
\text { deconstruction, exterior maintenance and operations, building maintenance } \\
\text { and operations, security operations }\end{array}$ \\
\hline General transportation & $\begin{array}{l}\text { onsite receiving and transportation, offsite transportation, security } \\
\text { operations }\end{array}$ \\
\hline Radioactive and mixed waste & laboratory and test activities \\
\hline Hazardous waste & $\begin{array}{l}\text { medical operations, laboratory and test activities, facilities construction and } \\
\text { deconstruction, exterior maintenance and operations, building maintenance } \\
\text { and operations, security operations, office operations }\end{array}$ \\
\hline Biological agents & laboratory and test activities \\
\hline Radiological materials & laboratory and test activities \\
\hline Contaminated sites & general environmental operations \\
\hline Solid waste (non-hazardous) & $\begin{array}{l}\text { office operations, medical operations, laboratory and test activities, } \\
\text { facilities construction and deconstruction, building maintenance and } \\
\text { operations, security operations, onsite receiving and transportation }\end{array}$ \\
\hline Legacy asbestos & $\begin{array}{l}\text { facilities construction and deconstruction, exterior maintenance and } \\
\text { operations, building maintenance and operations }\end{array}$ \\
\hline Natural gas use & office operations, medical operations, laboratory and test activities \\
\hline Water use & $\begin{array}{l}\text { office operations, medical operations, laboratory and test activities, exterior } \\
\text { maintenance and operations, facilities construction and deconstruction, } \\
\text { building maintenance and operations }\end{array}$ \\
\hline
\end{tabular}




\begin{tabular}{ll}
\hline Hazardous material transportation & onsite receiving and transportation, offsite transportation \\
\hline Electricity use & office operations, medical operations, laboratory and test activities \\
\hline Fire & emergency event \\
\hline Earthquake & emergency event \\
\hline
\end{tabular}

\subsection{Significant Environmental Aspects}

Significant environmental aspects for SNL/CA were identified through the risk ranking process described in Section 5.3. The site's significant aspects are those with the highest risk score under normal operations: water discharges, air emissions, land use, general transportation, and hazardous waste. Table 4 provides the complete list of SNL/CA aspects for 2009 along with the ranking score from the risk assessment process for both normal operations and off-normal events. Significant environmental aspects are highlighted in bold. The risk ranking for offnormal events is also shown in Table 4. Although only one of the highest ranked aspects in offnormal situations (highlighted in italics) is categorized as a significant aspect, all of these offnormal high risks are addressed during the establishment of action items. Table 5 shows the changes in SNL/CA's significant environmental aspects between 2008 and 2009.

Table 4 SNL/CA Environmental Aspects

\begin{tabular}{|lllllc}
\hline Aspect & \multicolumn{2}{c}{ Ranking Score $^{\mathbf{a}}$} & Aspect & \multicolumn{2}{c}{ Ranking Score $^{\mathbf{a}}$} \\
& Normal & $\begin{array}{l}\text { Off- } \\
\text { Normal }\end{array}$ & & $\begin{array}{c}\text { Off- } \\
\text { Normal } \\
\text { Normal }\end{array}$ \\
\hline Water discharges & $\mathbf{1 2 . 6}$ & 20 & Water use & 5.4 & 18 \\
\hline Air emissions & $\mathbf{1 2}$ & 8 & Radioactive and mixed waste & 5 & 42 \\
\hline Land use & $\mathbf{1 1}$ & 15 & Biological agents & 5 & 52 \\
\hline General transportation & $\mathbf{1 1}$ & 1 & Natural gas use & 5 & 21 \\
\hline Hazardous waste & $\mathbf{9 . 6}$ & 45 & Electricity use & 5 & 11 \\
\hline Hazardous materials & 7 & 13 & Legacy asbestos & 4 & 34 \\
\hline Material procurement and use & 6.3 & 1 & Hazardous material transportation & 3.6 & 44 \\
\hline Radioactive materials & 6 & 24 & EMERGENCY ASPECTS & & \\
\hline Solid waste (non-hazardous) & 5.5 & 10 & Fire & 0 & 22 \\
\hline Contaminated sites & 5.5 & 0 & Earthquake & 0 & 26
\end{tabular}

${ }^{a}$ See Section 5.3 for description of methodology used to rank environmental aspects.

Table 5 Change in Significant Environmental Aspects Between 2008 and 2009

\begin{tabular}{ll}
\hline 2008 Significant Aspects & 2009 Significant Aspects \\
\hline Water discharges & Water discharges \\
\hline Air emissions & Air emissions \\
\hline Land use & Land use \\
\hline Material procurement and use & General transportation \\
\hline Universal waste & Hazardous waste \\
\hline Hazardous materials & \\
\hline
\end{tabular}




\section{Quality Assurance and Risk Management}

The Sandia Corporate Quality Assurance (QA) Program, defined in CG 100.5 (SNL 2009b) is implemented in California through the Sandia National Laboratories Division 8000 QA Program. The Division 8000 QA Program establishes the quality management system for planning work, evaluating work, implementing controls, performing work, and improving processes. The Division QA Program directs all SNL/CA departments to evaluate the hazards associated with their activities using the ISMS primary hazard screening (PHS) software tool. It also requires each department to perform activity or program risk assessments in order to determine the formality that must be used in managing these department activities or programs. Additionally, SNL/CA's Environmental Management Department completed a third quality-related evaluation, a risk ranking of EMS aspects to assist the department in focusing EMS Program efforts and resources on those aspects that represent the greatest risks to the site. Figure 5 shows the quality assurance process for the Environmental Management Department.

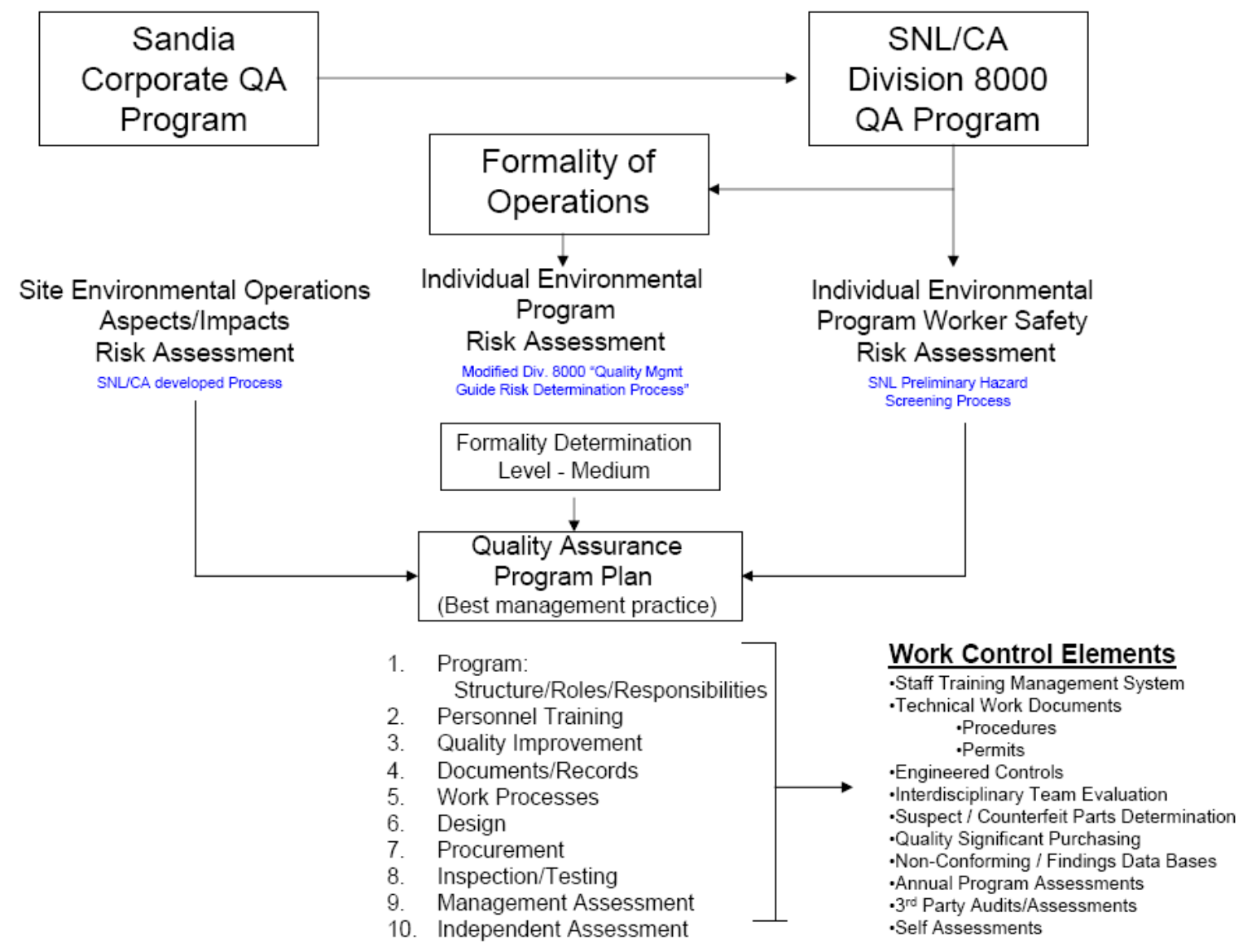

Figure 5 Environmental Management Department QA Process 


\subsection{Identifying and Managing Risk to Environmental Management Personnel}

The execution of each of the six EMS environmental programs introduces personal risks to the staff performing the various actions of these programs. SNL/CA uses the corporate PHS software tool as the first step in managing risk to environmental management personnel. The PHS assists action owners in identifying hazards using a detailed set of questions about all aspects of environment, safety, and health. The PHS software generates a hazard evaluation based on the answers provided, and identifies training requirements and safety controls needed to protect the workforce. Each functional environmental program maintains a program-specific PHS to manage the safety risks associated with program activities.

\subsection{Identifying and Managing Environmental Program Risk}

The Environmental Management Department completed a formality determination to identify and manage risk associated with each SNL/CA environmental program. The formality determination is required and outlined in the Division QA Program. In general, a formality determination is made by conducting a risk assessment to identify the risk category of a particular activity, or in this case, program. Under the Division QA Program, programs that fall within the high-risk category require work-specific quality assurance plans. Programs that fall within the medium risk category require supplemental controls as outlined in one of four quality management guides.

The formality determination for the Environmental Management Department was completed by assessing the unique program risks associated with each of the six environmental programs. These assessments followed the Division 8000 process, which is a modified version of the corporate process. The results of the assessments show that risks associated with environmental programs fall within the low and medium risk categories. Department activities fall within the Exemplary Operations guide and the use of quality best practices as supplemental controls. Although not required, the Environmental Management Department prepared a departmentspecific quality assurance plan as its quality best practice supplemental control.

\subsection{Identifying and Managing Risk Associated with Environmental Aspects}

Annually, the EMS Core Team ranks the environmental aspects identified through the EMS Program to evaluate the risks of SNL/CA operations. Environmental aspects are ranked first under normal operating conditions using a modified risk assessment process that accounts for existing controls, compliance programs, and EMS improvements made during the previous year. Each aspect is evaluated against nine exposure pathways and rated on an impact scale from zero to 3 (negligible to high consequence). The resulting risk score is then adjusted (either up or down) to account for changes that occurred in the previous year in funding, resources, knowledge, or activity level gained or lost. Figure 6 shows the assessment matrix for one 
environmental aspect under normal operating conditions. A second assessment of each aspect is performed for a plausible off-normal event (determined by the core team and listed for each aspect) using a similar risk assessment process with the addition of a probability index of zero to 4 (zero to very high probability of an occurrence). Figure 7 shows the assessment matrix for an environmental aspect for an off-normal event. Ranking results are compiled and presented in Figure 8. Figure 9 graphically shows a summary of the ranking assessment for both normal operations and off-normal events. As shown, the highest risk aspects associated with normal operations are different from those identified for off-normal events.

The results of the aspects risk analysis are used to validate the resources applied to the environmental program that manages those risks. The results are also used to help establish the set of actions for the year that are designed to:

- $\quad$ Reduce the impacts of high-risk normal operations;

- Reduce the probability of high-risk off-normal events;

- Reduce the consequences of high-risk off-normal events should they occur.

\subsection{Quality Assurance Program Plan}

The Environmental Management Department QA Program Plan (QAPP), dated March 23, 2006 documents the activities that are vital to assuring the quality of work performed by the department. It applies to all environmental programs within the department. Although not required by the formality determination, the QAPP was selected as the quality best practice to manage medium risk category activities and to ensure consistent application of quality practices for functional environmental programs as well as for the EMS Program. The QAPP addresses the ten QA criteria of an effective quality program identified by DOE. 
EMS Program Manual

April 2009

ASPECT: Water Discharges - Normal Operations

Operations

\begin{tabular}{||l|l|}
\hline & \\
Environmental Impact & \\
\hline Contamination of air & \\
\hline Contamination of ground water or surface water & \\
\hline Contamination of soil & \\
\hline Contamination of facilities (building or equipment) & \\
\hline Offsite disposal (landfill or long term storage) & \\
\hline Exposure to workforce & \\
\hline Exposure to public & \\
\hline Depletion of Natural Resources & \\
\hline Effect on Wildlife or Habitat & \\
\hline
\end{tabular}

\begin{tabular}{|l}
\hline \\
\hline \\
\hline
\end{tabular}

\begin{tabular}{|c|c|}
\hline \hline $\begin{array}{c}\text { Environmental } \\
\text { Damage }\end{array}$ & $\begin{array}{c}\text { Safety and } \\
\text { Health }\end{array}$ \\
\hline 0 & 0 \\
\hline 1 & 0 \\
\hline 1 & 0 \\
\hline 0 & 0 \\
\hline 0 & 0 \\
\hline 0 & 0 \\
\hline 0 & 0 \\
\hline 0 & 0 \\
\hline 1 & 0 \\
\hline
\end{tabular}

Risks of Impact

\begin{tabular}{|c|c|c|c|c|c|}
\hline $\begin{array}{l}\text { Programmatic } \\
\text { Impact }\end{array}$ & Compliance & $\begin{array}{c}\text { Financial } \\
\text { liability or cost }\end{array}$ & \begin{tabular}{|c|} 
Negative \\
Reputation or \\
Publicity \\
\end{tabular} & Total Risks & $\begin{array}{l}\text { Risk } \\
\text { Score }\end{array}$ \\
\hline 0 & 0 & 0 & 0 & 0 & 0 \\
\hline 1 & 2 & 2 & 2 & 8 & 8 \\
\hline 0 & 0 & 0 & 0 & 1 & 1 \\
\hline 0 & 1 & 1 & 0 & 2 & 2 \\
\hline 0 & 1 & 1 & 0 & 2 & 2 \\
\hline 0 & 0 & 0 & 0 & 0 & 0 \\
\hline 0 & 0 & 0 & 0 & 0 & 0 \\
\hline 0 & 0 & 0 & 0 & 0 & 0 \\
\hline \multirow[t]{3}{*}{0} & 0 & 0 & 0 & 1 & 1 \\
\hline & & & & & 14 \\
\hline & & & & $\begin{array}{l}\text { Probability } \\
\text { Adjustment } \\
\text { (multiplier) }\end{array}$ & 0.9 \\
\hline
\end{tabular}

\begin{tabular}{|r|c|c|}
\hline Risks & & Value \\
\hline Negligable & & 0 \\
\hline low & & 1 \\
\hline medium & & 2 \\
\hline high & & 3 \\
\hline
\end{tabular}

Total Score

\begin{tabular}{|r|l|c|}
\hline Probability Adjustment from Prior Year & degree of change & multiplier \\
\hline Loss of funding & & \\
\hline Loss of resources & & \\
\hline Increase level of activity & & \\
\hline Increase in funding & & \\
\hline Increase in resources & & 0.9 \\
\hline Decrease in knowledge & & \\
\hline
\end{tabular}

\begin{tabular}{|c|c|}
\hline $\begin{array}{c}\text { Degree of } \\
\text { Change }\end{array}$ & Prob. Mult. \\
\hline negligible & 1 \\
\hline low & $+/-10 \%$ \\
\hline medium & $+/-20 \%$ \\
\hline high & $+l-30 \%$ \\
\hline
\end{tabular}

Figure 6 Aspect Ranking Example - Normal Operations

\begin{tabular}{|c|c|c|c|c|c|c|c|c|c|}
\hline \multicolumn{2}{|l|}{ ASPECT: Water Discharges - Off Normal } & \multicolumn{7}{|c|}{ Risks of Impact } & \multirow[b]{2}{*}{$\begin{array}{l}\text { Risk } \\
\text { Score }\end{array}$} \\
\hline Environmental Impact & $\begin{array}{c}\text { Failure } \\
\text { Probability }\end{array}$ & $\begin{array}{c}\text { Environmental } \\
\text { Damage }\end{array}$ & $\begin{array}{l}\text { Safety and } \\
\text { Health }\end{array}$ & $\begin{array}{c}\text { Programmatic } \\
\text { Impact }\end{array}$ & Compliance & $\begin{array}{c}\text { Financial } \\
\text { liability or cost }\end{array}$ & \begin{tabular}{|c|} 
Negative \\
Reputation or \\
Publicity
\end{tabular} & Total Risks & \\
\hline Contamination of air & 1 & \begin{tabular}{|l|}
0 \\
\end{tabular} & 0 & 0 & 0 & 0 & 0 & 0 & 0 \\
\hline Contamination of ground water or surface water & 1 & 2 & 1 & 1 & 1 & 3 & 2 & 10 & 10 \\
\hline Contamination of soil & 1 & 0 & 0 & 0 & 0 & 0 & 0 & 0 & 0 \\
\hline Contamination of facilities (building or equipment) & 1 & 0 & 1 & 0 & 0 & 0 & 0 & 1 & 1 \\
\hline Offsite disposal (landfill or long term storage) & 1 & 1 & 0 & 0 & 0 & 0 & 0 & 1 & 1 \\
\hline Exposure to workforce & 1 & 0 & 0 & 0 & 0 & 0 & 0 & 0 & 0 \\
\hline Exposure to public & 1 & 0 & 1 & 0 & 0 & 1 & 2 & 4 & 4 \\
\hline Depletion of Natural Resources & 1 & 0 & 0 & 0 & 0 & 0 & 0 & 0 & 0 \\
\hline Effect on Wildlife or Habitat & 1 & 1 & 1 & 0 & 1 & 0 & 1 & 4 & 4 \\
\hline
\end{tabular}

\begin{tabular}{|r|c|c|}
\hline Probability & & Value \\
\hline zero or N/A & 0 & 0 \\
\hline Iow & $<20 \%$ & 1 \\
\hline medium & $20-50 \%$ & 2 \\
\hline high & $50-80 \%$ & 3 \\
\hline very high & $>80 \%$ & 4 \\
\hline \multicolumn{2}{|r|}{} \\
\hline Risks & & Value \\
\hline Negligable & 0 \\
\hline low & 1 \\
\hline medium & & 2 \\
\hline high & & 3 \\
\hline
\end{tabular}

Off Normal Scenario: An discharge from operations to the sanitary sewer that negatively affects operations at the Livermore sewer plant.

Figure 7 Aspect Ranking Example - Off-Normal Event 


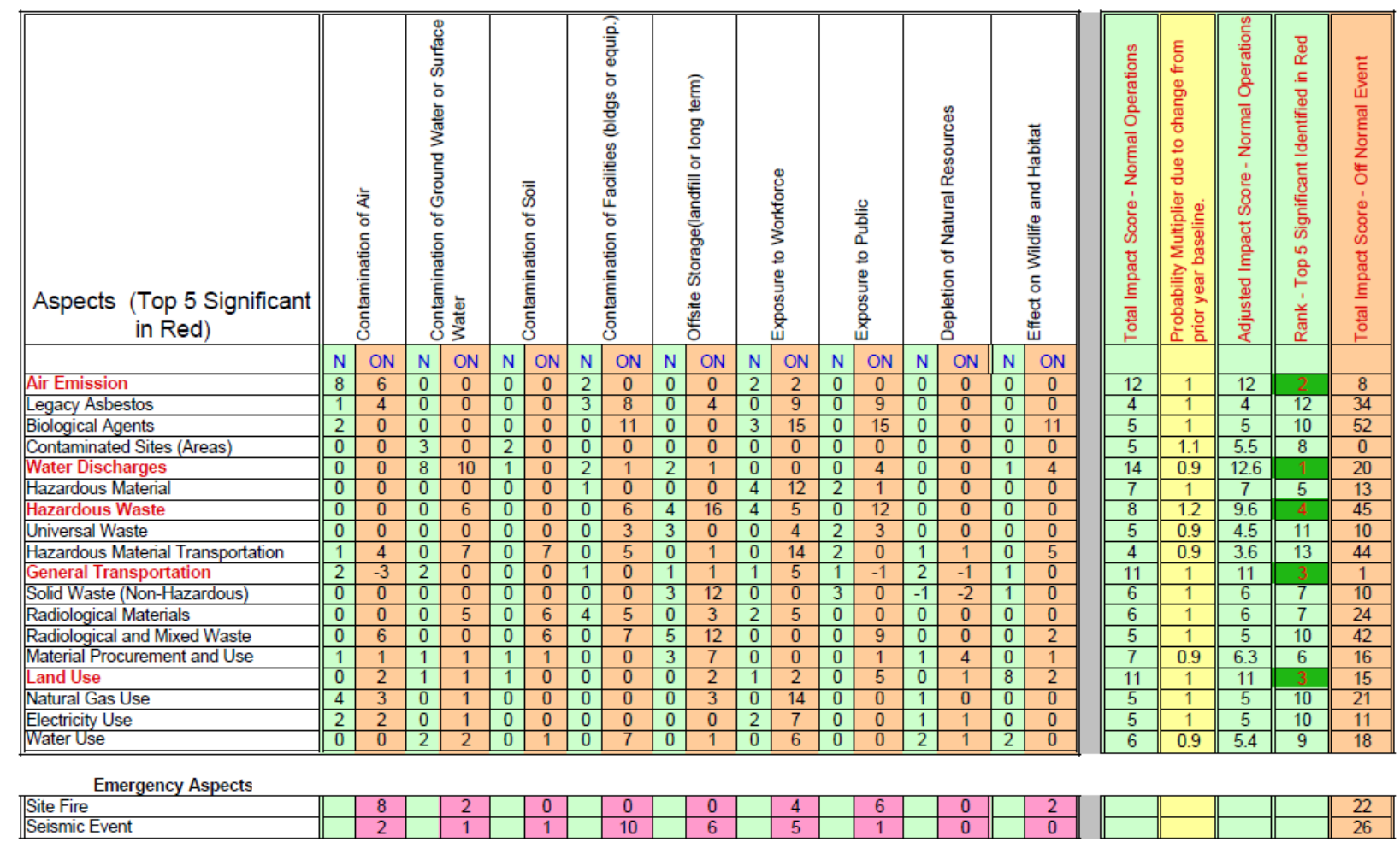

Figure 8 Environmental Aspect Ranking Results, 2008 


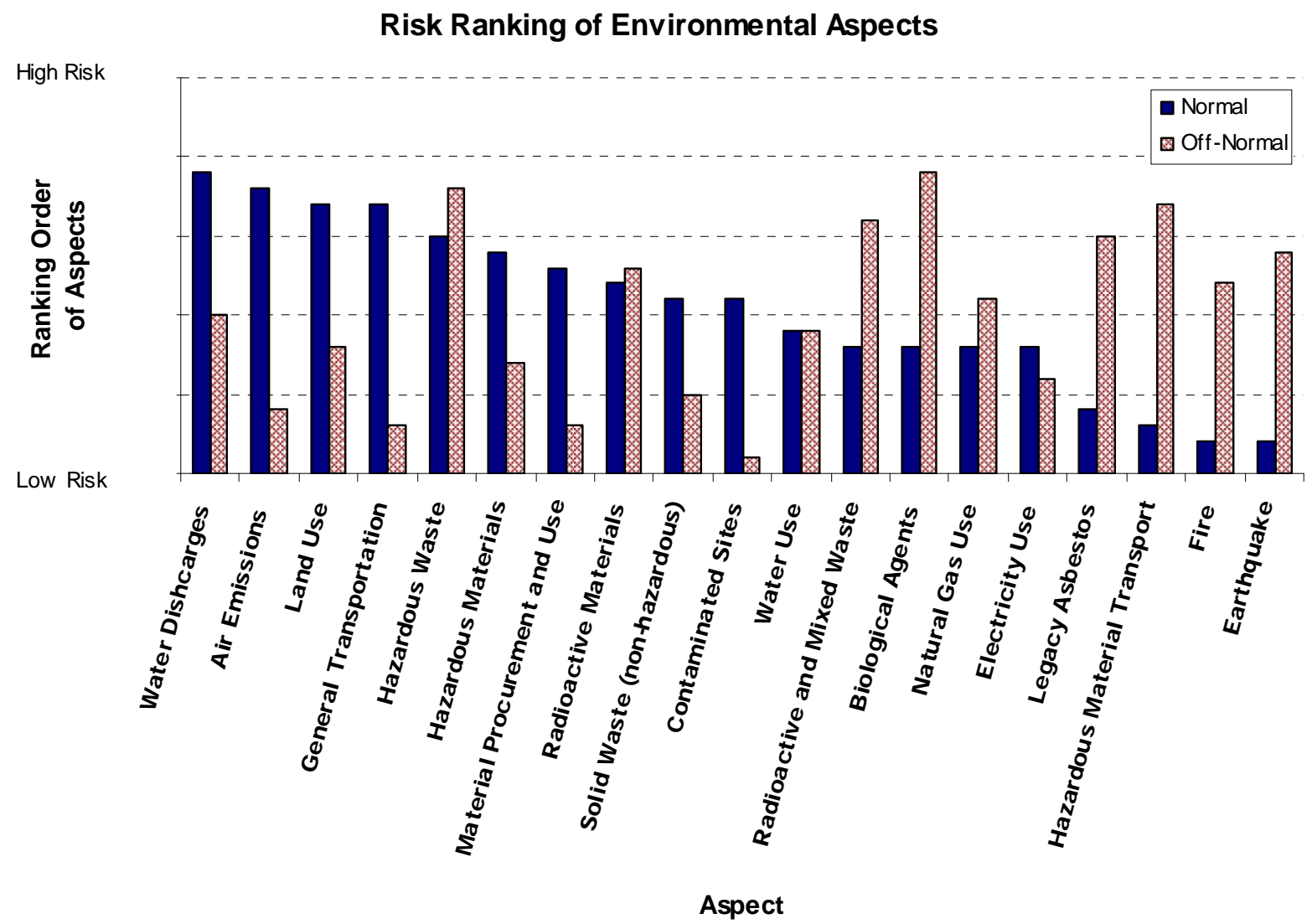

Figure 9 SNL/CA Aspect Ranking Summary 


\section{Objectives and Targets}

Setting objectives and targets, and establishing actions to help achieve these is a continuous cycle as shown in Figure 10. Objectives and targets provide a measure of environmental performance and the effectiveness of an EMS. SNL/CA's objectives support efforts to reduce potential environmental risk from site operations and enhance environmental stewardship. Our targets are detailed measurable performance requirements directly linked to site objectives. Each year, the EMS Core Team reviews EMS objectives and targets and evaluates the sites progress in meeting them. Targets are modified and new action items are established for the upcoming calendar year. As part of this review process, the Core Team identifies additional resources needed to implement current or future action items and submits an investment request through the budget cycle.

The site's senior management team (VP and directors) are responsible for approving new EMS objectives and targets, and validating existing objectives and targets annually. The management team approved and validated the 2009 EMS objectives and targets on October 30, 2008.

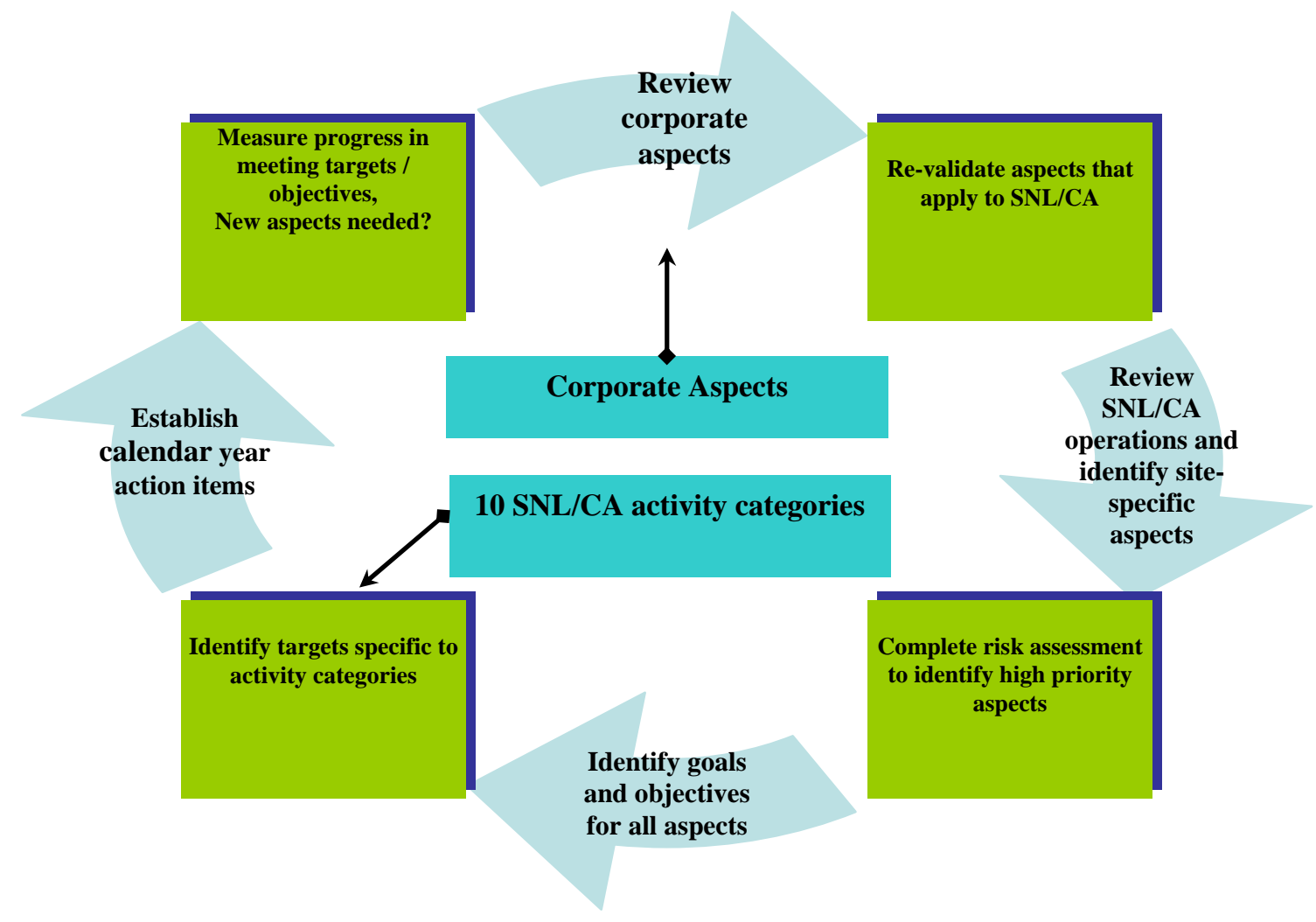

Figure 10 Cycle of Setting and Evaluating EMS Objectives and Targets 


\subsection{Defining Objectives}

In 2006, the EMS Core Team established broad, multi-year objectives for environmental aspects applicable to SNL/CA activities. The inclusion of objectives for each aspect rather than only significant aspects serves as a best business practice by providing an expectation of overall environmental stewardship across the spectrum of activities conducted on site. An additional objective for general environmental operations was also established in 2006.

Each EMS objective was formed around the concept that the site's negative environmental impacts cannot be eliminated, in most cases, but should be minimized to the extent practical. For example, site operations will continue to generate waste, use hazardous materials, etc, but these can be managed to reach a minimum level appropriate to the level of operations and mission of the site. SNL/CA EMS objectives are shown in Table 6. Objectives associated with significant environmental aspects are highlighted in green.

Table 6 SNL/CA EMS Objectives

\begin{tabular}{ll}
\hline Environmental Aspect/Area & Objective \\
\hline General Environmental & Provide exceptional environmental management for the SNL/CA site. \\
\hline Water Discharges & $\begin{array}{l}\text { Minimize the volume and contamination of sewer water. } \\
\text { Minimize the volume and pollution of storm water runoff. }\end{array}$ \\
\hline Air Emissions & $\begin{array}{l}\text { Minimize air emissions related to operations and transportation with particular } \\
\text { emphasis on Spare-the-Air days. }\end{array}$ \\
\hline Land Use & $\begin{array}{l}\text { Enhance the natural habitat. } \\
\text { Design and manage all buildings and facilities using "green" principles. }\end{array}$ \\
\hline General Transportation & Minimize the use of vehicles by members of the workforce. \\
\hline Hazardous Waste & Minimize the generation of hazardous waste. \\
\hline Hazardous Materials & Minimize the use of hazardous materials. \\
\hline Material Procurement and Use & Procure and use environmentally friendly products and materials. \\
\hline Radiological Material & Minimize the use of radiological materials. \\
\hline Radioactive and Mixed Waste & Minimize the generation of radioactive and mixed waste. \\
\hline Biological Agents & Minimize the use of biological materials. \\
\hline Contaminated Sites & Minimize the environmental impacts of site contaminated areas. \\
\hline Legacy Asbestos & Reduce site legacy asbestos material. \\
\hline Solid Waste (non-hazardous) & $\begin{array}{l}\text { Minimize the quantity of landfill waste through reduced consumption and/or } \\
\text { reuse/recycling. }\end{array}$ \\
\hline Hazardous Material & $\begin{array}{l}\text { Minimize the potential environmental effects of hazardous material due to } \\
\text { transportation. }\end{array}$ \\
\hline Natural Gas Use & Minimize site natural gas consumption. \\
\hline Water Use & Minimize site water consumption. \\
\hline Electrical Use & Minimize site electrical consumption. \\
\hline Fire & Minimize the environmental effects of a site fire emergency. \\
\hline Earthquake & Minimize the environmental effects of a site seismic event. \\
\hline
\end{tabular}




\subsection{Defining Targets and Assigning Actions}

Annually, the EMS Core Team establishes new targets and updates existing targets to support site environmental objectives. At a minimum, targets (or actions) are established for significant environmental aspects. The Core Team identifies specific actions, timeframes, and personnel assignments needed to meet these targets. Completion of actions and progress towards meeting established targets is tracked using standard project management software (i.e., FastTrack Schedule). Project management schedules for significant environmental aspects are presented in figures 11 through 15.

The EMS Core Team may also establish targets for environmental aspects that are not categorized as significant to support specific environmental program activities (e.g., activities that receive special funding, support corrective actions, or implement site initiatives). For example, in 2009, the Core Team established a target to increase the use of bio-based products by $25 \%$ by 2010, using 2008 as the baseline (aspect $=$ material procurement and use; objective = procure and use environmentally friendly products and materials). Actions to support targets not associated with significant environmental aspects are incorporated into routine environmental program activities and tracked to completion by functional program leads. The complete list of targets for 2009 is provided in Appendix A. 
EMS Program Manual

April 2009

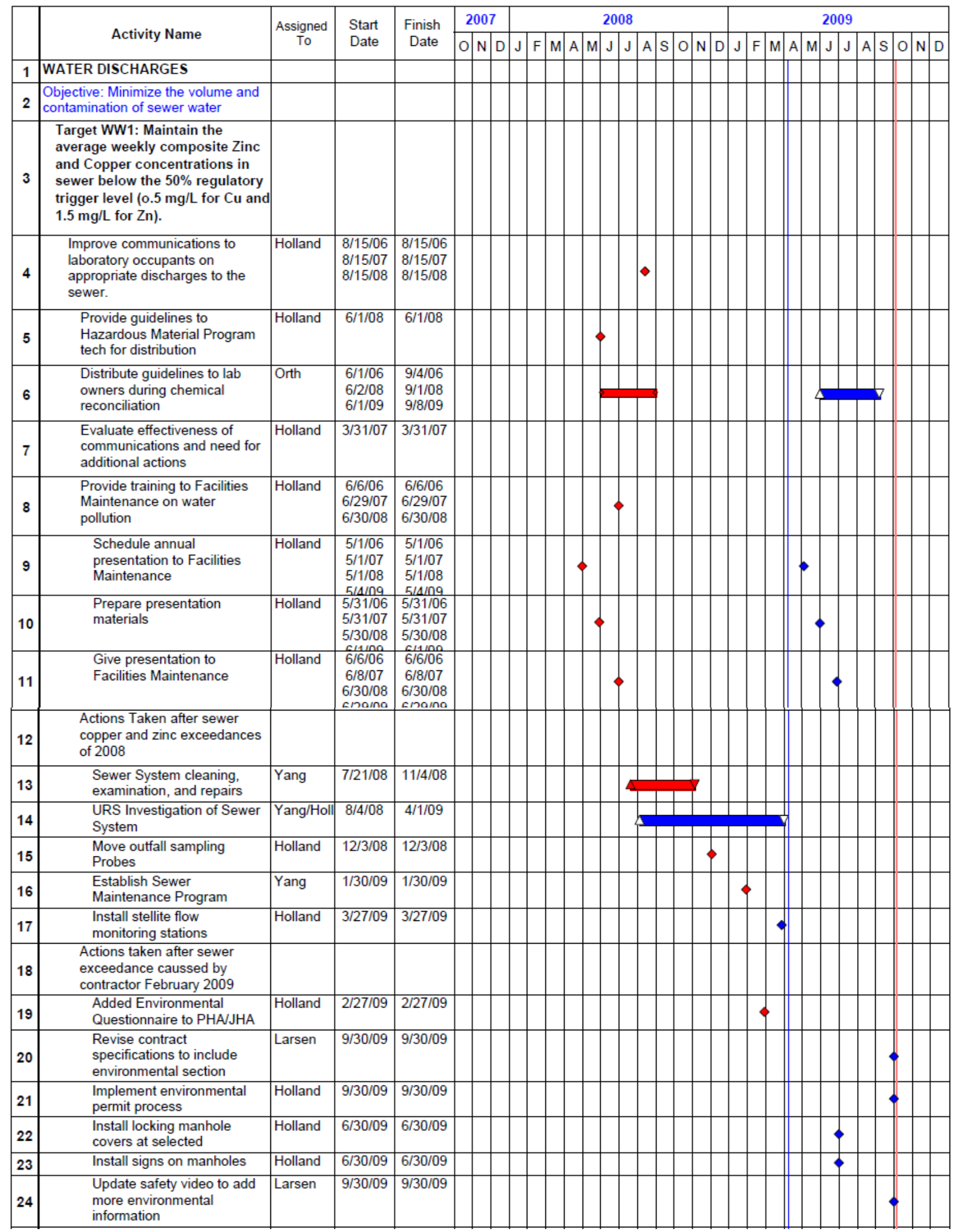

Figure 11 Water Discharges Objectives, Targets, and Actions 
EMS Program Manual

April 2009

\begin{tabular}{|c|c|c|c|c|c|c|c|c|c|c|c|c|c|c|c|c|c|c|c|c|c|c|c|c|c|c|c|}
\hline & \multirow{2}{*}{ Activity Name } & \multirow{2}{*}{$\begin{array}{l}\text { Assigned } \\
\text { To }\end{array}$} & \multirow{2}{*}{$\begin{array}{l}\text { Start } \\
\text { Date }\end{array}$} & \multirow{2}{*}{$\begin{array}{c}\text { Finish } \\
\text { Date }\end{array}$} & \multicolumn{3}{|c|}{2007} & \multicolumn{10}{|c|}{2008} & \multicolumn{10}{|c|}{2009} \\
\hline & & & & & $\mathrm{O}$ & $\mathrm{N}$ & $\mathrm{D}$ & $\mathrm{F}$ & M & A & $\mathrm{M}$. & $J$ & A & S & $\mathrm{O}$ & $\mathrm{N}$ & D & J & N & A & & & & $s$ & 0 & $\mathrm{~N}$ & D \\
\hline 25 & & & & & & & & & & & & & & & & & & & & & & & & & & & \\
\hline 26 & $\begin{array}{l}\text { Objective: Minimize the volume and } \\
\text { pollution of storm water runoff }\end{array}$ & & & & & & & & & & & & & & & & & & & & & & & & & & \\
\hline 27 & $\begin{array}{l}\text { Target SW1: By September 1st } \\
\text { of each year implement runoff } \\
\text { controls for } 100 \% \text { of bulk } \\
\text { erodable landscape and } \\
\text { construction material. }\end{array}$ & & & & & & & & & & & & & & & & & & & & & & & & & & \\
\hline 28 & $\begin{array}{l}\text { Identify all construction that will } \\
\text { be scheduled during rainy } \\
\text { season and assure erosion } \\
\text { controls will be included and } \\
\text { highlighted to PM and } \\
\text { contractor. }\end{array}$ & Holland & $\begin{array}{l}7 / 31 / 06 \\
7 / 31 / 07 \\
7 / 31 / 08 \\
7 / 27 / 09\end{array}$ & $\begin{array}{l}9 / 1 / 06 \\
9 / 3 / 07 \\
9 / 1 / 08 \\
9 / 7 / 09\end{array}$ & & & & & & & & & & & & & & & & & & & & & & & \\
\hline 29 & $\begin{array}{l}\text { Conduct a site drive tour to } \\
\text { identify materials needing } \\
\text { erosion controls }\end{array}$ & \begin{tabular}{|l|} 
Holland \\
Chavarria
\end{tabular} & $\begin{array}{l}8 / 1 / 06 \\
8 / 1 / 07 \\
8 / 1 / 08\end{array}$ & $\begin{array}{l}9 / 4 / 06 \\
9 / 3 / 07 \\
9 / 2 / 08\end{array}$ & & & & & & & & & & & & & & & & & & & & 8 & & & \\
\hline 30 & $\begin{array}{l}\text { Notify owners of material } \\
\text { locations that need erosion } \\
\text { control }\end{array}$ & Holland & $\begin{array}{l}8 / 25 / 06 \\
8 / 24 / 07 \\
8 / 25 / 08\end{array}$ & $\begin{array}{l}8 / 25 / 06 \\
8 / 24 / 07 \\
8 / 25 / 08\end{array}$ & & & & & & & & & & 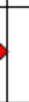 & & & & & & & & & & & & & \\
\hline 31 & $\begin{array}{l}\text { Assist material owners with } \\
\text { identifying funding for tarps } \\
\text { and other needed controls }\end{array}$ & Holland & $\begin{array}{l}8 / 1 / 06 \\
8 / 1 / 07 \\
8 / 1 / 08\end{array}$ & $\begin{array}{l}9 / 1 / 06 \\
9 / 3 / 07 \\
9 / 2 / 08\end{array}$ & & & & & & & & & & & & & & & & & & & & 8 & & & \\
\hline 32 & Implement controls & Clevenge & $\begin{array}{l}9 / 1 / 06 \\
10 / 1 / 07 \\
10 / 1 / 08\end{array}$ & $\begin{array}{l}9 / 1 / 06 \\
10 / 1 / 07 \\
10 / 1 / 08\end{array}$ & & & & & & & & & & & 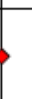 & & & & & & & & & & & & \\
\hline 33 & $\begin{array}{l}\text { Conduct a survey to record the } \\
\% \text { of total piles that have runoff } \\
\text { controls in place. }\end{array}$ & \begin{tabular}{l|} 
Holland \\
Chavarria
\end{tabular} & $\begin{array}{l}10 / 1 / 1 / 06 \\
9 / 1 / 06 \\
10 / 1 / 07 \\
10 / 1 / 08\end{array}$ & $\begin{array}{l}10 / 1 / 1 / 06 \\
10 / 1 / 07 \\
10 / 1 / 08\end{array}$ & & & & & & & & & & & 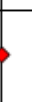 & & & & & & & & & & & & \\
\hline 34 & $\begin{array}{l}\text { Evaluate noncompliances and } \\
\text { correct deficiencies }\end{array}$ & \begin{tabular}{|l|} 
Holland \\
Clevenge
\end{tabular} & $\begin{array}{l}10 / 1 / 06 \\
9 / 1 / 1 / 06 \\
10 / 1 / 07 \\
10 / 1 / 08 \\
10 / 5 / 09\end{array}$ & $\begin{array}{l}19 / 11 / 06 \\
10 / 8 / 07 \\
10 / 8 / 08 \\
10 / 5 / 109\end{array}$ & & & & & & & & & & & 色 & & & & & & & & & & & & \\
\hline 35 & $\begin{array}{l}\text { Target SW2: } 100 \% \text { inspection } \\
\text { and cleaning of on-site storm } \\
\text { drain system including drop } \\
\text { structure by October } 1 \text { of each } \\
\text { year }\end{array}$ & & & & & & & & & & & & & & & & & & & & & & & & & & \\
\hline 36 & $\begin{array}{l}\text { Verify that storm drain cleaning } \\
\text { is included in Maximo }\end{array}$ & Holland & $5 / 30 / 08$ & $5 / 30 / 08$ & & & & & & & & & & & & & & & & & & & & & & & \\
\hline 37 & $\begin{array}{l}\text { Present storm water discharge } \\
\text { awareness and controls to } \\
\text { Landscape crew }\end{array}$ & Holland & $6 / 30 / 08$ & $6 / 30 / 08$ & & & & & & & & & & & & & & & & & & & & & & & \\
\hline 38 & $\begin{array}{l}\text { Verify on October } 1 \text { the percent } \\
\text { of storm drains cleaned }\end{array}$ & Holland, & $\begin{array}{l}10 / 2 / 06 \\
10 / 1 / 07 \\
10 / 1 / 08 \\
10 / 1 / 09\end{array}$ & $\begin{array}{l}10 / 2 / 06 \\
10 / 1 / 07 \\
10 / 1 / 08 \\
10 / 5 / 09\end{array}$ & & & & & & & & & & & & & & & & & & & & & & & \\
\hline 39 & $\begin{array}{l}\text { Target SW3: } 100 \% \text { of new } \\
\text { construction will have } \\
\text { post-construction runoff equal to } \\
\text { or less than pre-construction } \\
\text { runoff. }\end{array}$ & & & & & & & & & & & & & & & & & & & & & & & & & & \\
\hline 40 & $\begin{array}{l}\text { Actions will be identified when } \\
\text { new construction is defined. }\end{array}$ & & & & & & & & & & & & & & & & & & & & & & & & & & \\
\hline
\end{tabular}

Figure 11 Water Discharges Objectives, Targets, and Actions (continued) 
EMS Program Manual

April 2009

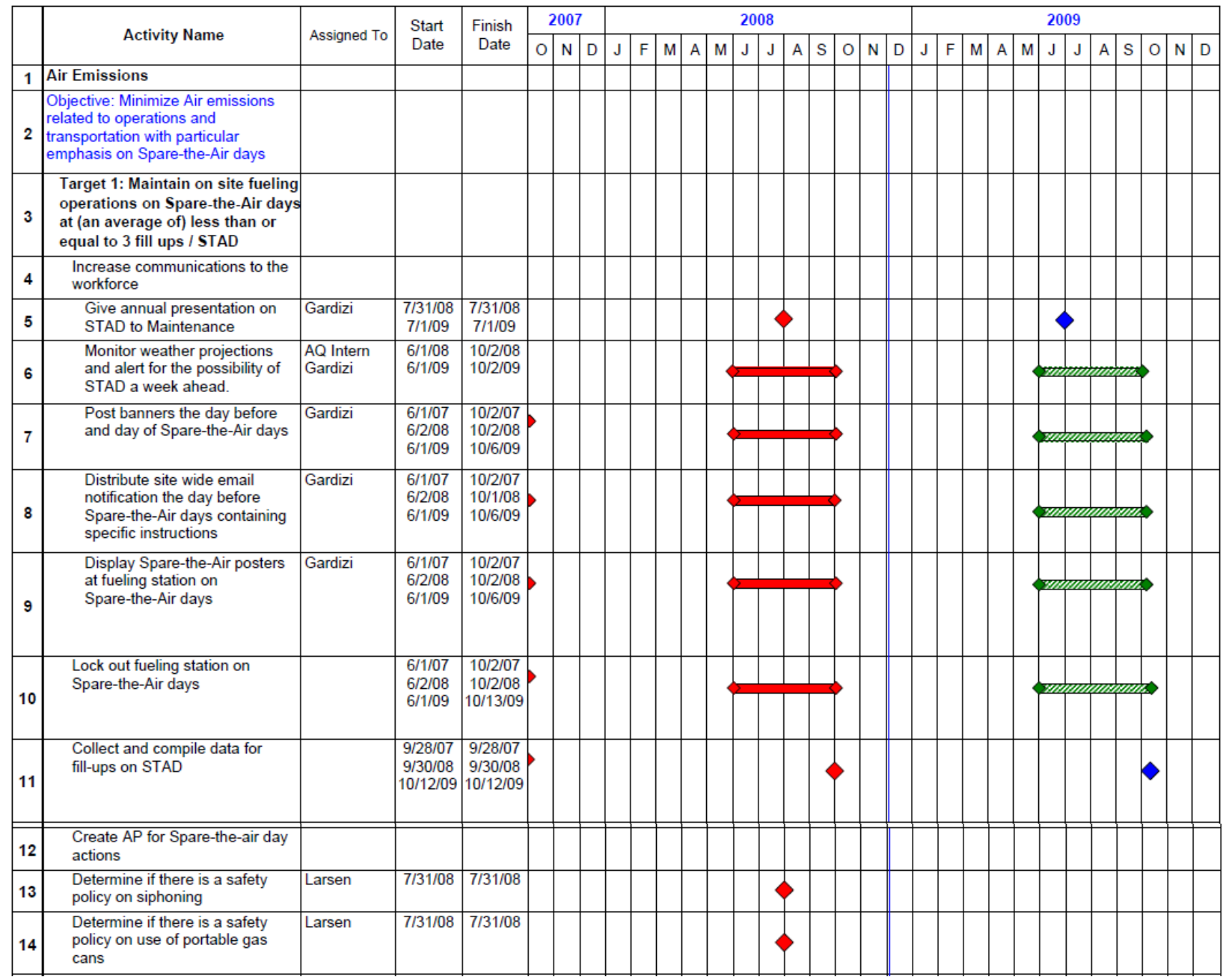

Figure 12 Air Emissions Objectives, Targets, and Actions 
EMS Program Manual

April 2009

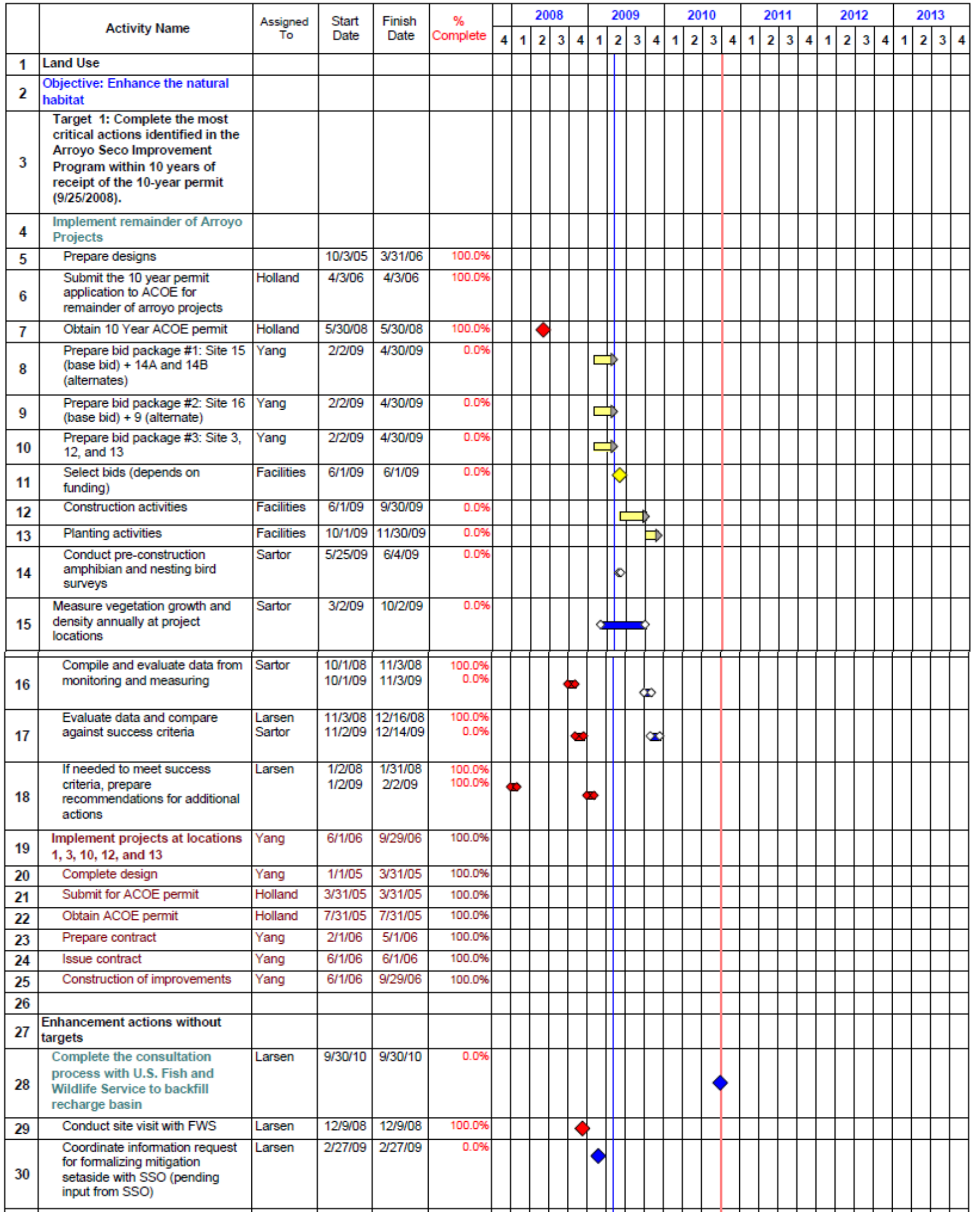

Figure 13 Land Use Objectives, Targets, and Actions 
EMS Program Manual

April 2009

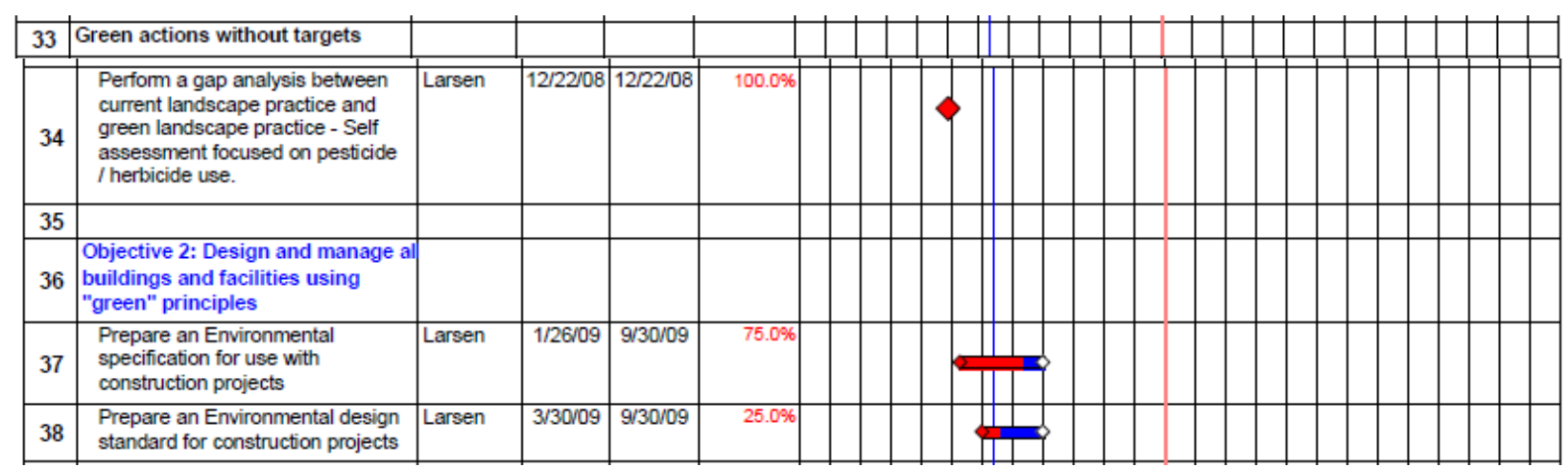

Figure 13 Land Use Objectives, Targets, and Actions (continued) 
EMS Program Manual

\begin{tabular}{|c|c|c|c|c|c|c|c|c|c|c|c|c|c|c|c|c|c|c|c|c|c|c|c|c|c|c|c|}
\hline & \multirow{2}{*}{ Activity Name } & \multirow{2}{*}{$\begin{array}{c}\text { Assigned } \\
\text { To }\end{array}$} & \multirow{2}{*}{$\begin{array}{l}\text { Start } \\
\text { Date }\end{array}$} & \multirow{2}{*}{$\begin{array}{c}\text { Finish } \\
\text { Date }\end{array}$} & \multicolumn{3}{|c|}{2006} & \multicolumn{4}{|c|}{2007} & \multicolumn{3}{|c|}{2008} & \multicolumn{3}{|c|}{2009} & \multicolumn{3}{|c|}{2010} & \multicolumn{3}{|c|}{2011} & \multicolumn{4}{|c|}{2012} \\
\hline & & & & & 1 & 2 & 4 & 1 & 2 & 3 & \begin{tabular}{l|l}
4 & 1
\end{tabular} & 2 & 3 & 4 & 1 & 3 & 4 & 1 & \begin{tabular}{l|l}
2 & 3 \\
$r$ & $x-1$
\end{tabular} & \begin{tabular}{l|l}
3 & 4
\end{tabular} & 1 & \begin{tabular}{|l|l}
2 & 3 \\
\end{tabular} & \begin{tabular}{l|l|l}
3 & 4
\end{tabular}$\longrightarrow$ & 1 & 2 & 3 & $\begin{array}{lllllll} & & & & \\
\end{array}$ \\
\hline \begin{tabular}{l|l}
1 & 1 \\
\end{tabular} & General Transportation & & & & & & & & & & & & & & & & & & & & & & & & & & \\
\hline 2 & $\begin{array}{l}\text { Objective 1: Maximize the use of } \\
\text { commute alternatives by members } \\
\text { of the workforce }\end{array}$ & & & & & & & & & & & & & & & & & & & & & & & & & & \\
\hline 3 & $\begin{array}{l}\text { Target 1: In 2015, increase the } \\
\text { use of single driver commute } \\
\text { alternatives by } 25 \% \text { from the } \\
\text { FY06 commuter survey } \\
\text { established baseline. }\end{array}$ & & & & & & & & & & & & & & & & & & & & & & & & & & \\
\hline 4 & $\begin{array}{l}\text { Conduct site survey to } \\
\text { establish baseline for \# miles } \\
\text { for each transportation type } \\
\text { (single occupant, carpool, } \\
\text { vanpool, bus, train, walk, bike, } \\
\text { etr) }\end{array}$ & Gardizi & $12 / 15 / 06$ & $12 / 15 / 06$ & & & $\leftrightarrow$ & & & & & & & & & & & & & & & & & & & & \\
\hline 5 & Design survey tool & Gardizi & $8 / 1 / 06$ & 9/29/06 & & 8 & 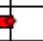 & & & & & & & & & & & & & & & & & & & & \\
\hline 6 & Implement survey & Gardizi & $10 / 2 / 06$ & $10 / 31 / 06$ & & & $\frac{1}{2}$ & & & & & & & & & & & & & & & & & & & & \\
\hline 7 & Compile data & Shamber & $8 / 1 / 07$ & $8 / 31 / 07$ & & & & & & ; & & & & & & & & & & & & & & & & & \\
\hline 8 & $\begin{array}{l}\text { Evaluate results and } \\
\text { determine baseline }\end{array}$ & Shamber & $9 / 3 / 07$ & 9/21/07 & & & & & & 8 & & & & & & & & & & & & & & & & & \\
\hline 9 & Develop new target & Core Tean & $8 / 31 / 07$ & $8 / 31 / 07$ & & & & & & $\Delta$ & & & & & & & & & & & & & & & & & \\
\hline 10 & $\begin{array}{l}\text { Present results of commuter } \\
\text { survey to EMS Advisory Team }\end{array}$ & Shamber & 9/5/07 & 9/5/07 & & & & & & 4 & & & & & & & & & & & & & & & & & \\
\hline 11 & $\begin{array}{l}\text { Obtain recommendations from } \\
\text { Advisory Team on actions to } \\
\text { support new target }\end{array}$ & Core Tean & $9 / 5 / 07$ & 9/5/07 & & & & & & $\Delta$ & & & & & & & & & & & & & & & & & \\
\hline 12 & $\begin{array}{l}\text { Contact Benefits (corporate) to } \\
\text { discuss feasiblity of RSA } \\
\text { commuter account }\end{array}$ & Shamber & $2 / 25 / 08$ & $2 / 25 / 08$ & & & & & & & 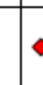 & & & & & & & & & & & & & & & & \\
\hline 13 & $\begin{array}{l}\text { Present survey results to } \\
\text { SHEAC }\end{array}$ & Shamber & $3 / 11 / 08$ & $3 / 11 / 08$ & & & & & & & 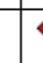 & of & & & & & & & & & & & & & & & \\
\hline 14 & $\begin{array}{l}\text { Seek management } \\
\text { committments on altemative } \\
\text { commute options }\end{array}$ & Shamber & $3 / 11 / 08$ & $3 / 11 / 08$ & & & & & & & & a & & & & & & & & & & & & & & & \\
\hline 15 & $\begin{array}{l}\text { Communicate results of } \\
\text { commuter survey to MOW }\end{array}$ & Shamber & $4 / 30 / 08$ & $4 / 30 / 08$ & & & & & & & & $b$ & & & & & & & & & & & & & & & \\
\hline 16 & $\begin{array}{l}\text { Publish a "shaker" on the } \\
8000 \text { webpage }\end{array}$ & Shamber & $2 / 29 / 08$ & $2 / 29 / 08$ & & & & & & & $<$ & & & & & & & & & & & & & & & & \\
\hline 17 & $\begin{array}{l}\text { Publish TNTs about } \\
\text { commuter survey results }\end{array}$ & Shamber & $2 / 11 / 08$ & $2 / 29 / 08$ & & & & & & & - & & & & & & & & & & & & & & & & \\
\hline 18 & $\begin{array}{l}\text { Conduct brown bag seminar } \\
\text { on commuter survey results } \\
\text { and altematives - canceled }\end{array}$ & Shamber & $12 / 19 / 08$ & $12 / 19 / 08$ & & & & & & & & & & & & & & & & & & & & & & & \\
\hline 19 & $\begin{array}{l}\text { Conduct a follow-up commuter } \\
\text { survey to determine potential } \\
\text { effects from increased } \\
\text { commuter support (per } \\
\text { SHEAC recommendation) }\end{array}$ & Shamber & $7 / 1 / 108$ & 9/30/08 & & & & & & & & & & & & & & & & & & & & & & & \\
\hline 20 & $\begin{array}{l}\text { Define first set of actions to } \\
\text { meet target }\end{array}$ & Core Tean & $10 / 1 / 08$ & $\mid 12 / 19 / 08$ & & & & & & & & & & 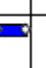 & & & & & & & & & & & & & \\
\hline 21 & $\begin{array}{l}\text { Review and modify actions } \\
\text { annually }\end{array}$ & Core Tean & \begin{tabular}{|l|}
$9 / 30 / 09$ \\
$9 / 30 / 10$ \\
$9 / 30 / 11$ \\
$10 / 1 / 12$ \\
$9 / 10 / 13$ \\
$9 / 30 / 14$ \\
\end{tabular} & \begin{tabular}{|l|}
$9 / 30 / 09$ \\
$9 / 30 / 10$ \\
$9 / 30 / 11$ \\
$10 / 11 / 12$ \\
$9 / 30 / 13$ \\
$9 / 30 / 14$ \\
\end{tabular} & & & & & & & & & & & & & 4 & & & & & & & & & & \\
\hline 22 & $\begin{array}{l}\text { Communicate about } \\
\text { carpooling and altemative } \\
\text { options for commuters }\end{array}$ & Core Tean & $\begin{array}{l}12 / 15 / 06 \\
6 / 15 / 07 \\
6 / 15 / 08 \\
6 / 15 / 09\end{array}$ & $\begin{array}{l}12 / 15 / 06 \\
6 / 15 / 07 \\
6 / 115 / 08 \\
6 / 15 / 09\end{array}$ & & & 4 & & & & & & & & & & & & & & & & & & & & \\
\hline
\end{tabular}

Figure 14 General Transportation Objectives, Targets, and Actions 
EMS Program Manual

April 2009

\begin{tabular}{|c|c|c|c|c|c|c|c|c|c|c|c|c|c|c|c|c|}
\hline & \multirow{2}{*}{ Activity Name } & \multirow{2}{*}{ Assigned To } & \multirow{2}{*}{$\begin{array}{l}\text { Start } \\
\text { Date }\end{array}$} & \multirow{2}{*}{$\begin{array}{c}\text { Finish } \\
\text { Date }\end{array}$} & \multirow{2}{*}{$\begin{array}{c}\% \\
\text { Complete }\end{array}$} & \multicolumn{11}{|c|}{2009} \\
\hline & & & & & & $F$ & $\mathrm{M}$ & A & $\mathrm{M}$ & $\mathrm{J}$ & $\mathrm{J}$ & A & S & 0 & $\mathrm{~N}$ & D \\
\hline 1 & Hazaardous Waste & & & & & & & & & & & & & & & \\
\hline 2 & $\begin{array}{l}\text { Objective: Minimize the generation } \\
\text { of hazardous waste }\end{array}$ & & & & & & & & & & & & & & & \\
\hline 3 & Target: No current target & & & & & & & & & & & & & & & \\
\hline 4 & $\begin{array}{l}\text { Conduct an evaluation to } \\
\text { determine if less expensive to } \\
\text { use an oil recycler for } \\
\text { management of waste oil and } \\
\text { oil filters. }\end{array}$ & Harris & $12 / 1 / 08$ & $6 / 30 / 09$ & $0.0 \%$ & & & & & & & & & & & \\
\hline 5 & $\begin{array}{l}\text { Conduct an evaluation of } \\
\text { different toner cartridge } \\
\text { recyclers to determine best } \\
\text { option for SNL/CA. }\end{array}$ & Harris & $1 / 29 / 09$ & $6 / 30 / 09$ & $0.0 \%$ & & & & & & & & & & & \\
\hline 6 & $\begin{array}{l}\text { Investigate how SNL/NM and } \\
\text { LLNL manage contractor } \\
\text { generated hazardous waste }\end{array}$ & Larsen & $6 / 30 / 09$ & $6 / 30 / 09$ & $100.0 \%$ & & & & & & & & & & & \\
\hline 7 & $\begin{array}{l}\text { Review and modify contract } \\
\text { verbiage (as needed) to include } \\
\text { sub-contractor responsibilities } \\
\text { for managing their hazardous } \\
\text { waste }\end{array}$ & Larsen & $6 / 30 / 09$ & $9 / 30 / 09$ & $100.0 \%$ & & & & & & & & & & & \\
\hline 8 & $\begin{array}{l}\text { Change the process for } \\
\text { managing empty aerosol } \\
\text { containers as scrap metal } \\
\text { instead of hazardous waste }\end{array}$ & Harris & $1 / 30 / 09$ & $1 / 30 / 09$ & $100.0 \%$ & & & & & & & & & & & \\
\hline 9 & $\begin{array}{l}\text { Recall flammable compressed } \\
\text { gas dusters. }\end{array}$ & Harris & $11 / 14 / 08$ & $11 / 20 / 08$ & $100.0 \%$ & & & & & & & & & & & \\
\hline 10 & $\begin{array}{l}\text { Communicate to MOW the } \\
\text { nonflammable type of } \\
\text { compressed gas dusters } \\
\text { available for purchase that can } \\
\text { be managed as scrap metal. }\end{array}$ & Harris & $11 / 14 / 08$ & $11 / 20 / 08$ & $100.0 \%$ & & & & & & & & & & & \\
\hline 11 & $\begin{array}{l}\text { Modified the process used to } \\
\text { recycle lead acid batteries to } \\
\text { ship directly to recycler instead } \\
\text { of through the TSDF }\end{array}$ & Harris & $3 / 31 / 09$ & $3 / 31 / 09$ & $100.0 \%$ & & & & & & & & & & & \\
\hline 12 & $\begin{array}{l}\text { Change process to manage } \\
\text { lead metal as scrap metal } \\
\text { instead of hazardous waste. }\end{array}$ & Harris & $10 / 31 / 08$ & $10 / 31 / 08$ & $100.0 \%$ & & & & & & & & & & & \\
\hline & & & & & & $\mathrm{F}$ & $\mathrm{M}$ & A & M & $\mathrm{J}$ & $\mathrm{J}$ & A & S & $\mathrm{O}$ & $\mathrm{N}$ & $\mathrm{D}$ \\
\hline
\end{tabular}

Figure 15 Hazardous Waste Objectives and Actions 


\section{Emergency Preparedness and Response}

SNL/CA has an established Emergency Plan (SNL/CA 2008d) and procedures to provide an effective and timely response to emergency conditions. The site's Emergency Management Program was established in accordance with a separate DOE order, Order 151.1C, Comprehensive Emergency Management System (DOE 2005). SNL/CA's Emergency Plan establishes guidelines and procedures to mitigate the potential consequences of an operational emergency. The Emergency Management Program maintains implementing procedures for all assigned roles that support emergency events on site. SNL/CA conducts annual training exercises to validate elements of the Emergency Management Program. Routine training drills and communication tests are also completed. The Emergency Plan and Emergency Plan Implementing Procedures are available to the site workforce on SNL/CA's web site at http://surf.ran.sandia.gov/centers/8500/security/em.

Emergency response actions support our EMS Program by managing and mitigating the potential environmental risk from site operations. During site emergencies, members of the Environmental Management Department provide support with hazardous materials spill response and clean-up. Through these efforts, potential long-term environmental effects are avoided or minimized. The Chemical Inventory System, managed by the Hazardous Material Management Program, one of the six environmental programs, provides invaluable information in support of the Emergency Management Program. 


\section{Environmental Programs}

SNL/CA maintains an Environmental Management Department that manages six functional program areas supporting the site EMS Program. The program leads from each of these six programs are part of the EMS Core Team responsible for developing, implementing, and modifying the site EMS. Functional program areas are:

- Air Quality

- Environmental Monitoring

- Environmental Planning and Ecology

- Hazardous Materials Management

- Pollution Prevention and Waste Minimization

- Waste Management

The program lead for each functional area prepares an annual report that provides detailed information about all aspects of program operations. The program reports are provided in Appendix B and include the following:

- A detailed summary of program activities

- Program drivers

- Operational controls

- Documents produced

- Job descriptions, qualifications, and training

- Performance measures

- Quality assurance / program risk assessment

- Program assessments

- Accomplishments in the last 12 months

- Trends

- Goals and objectives (short-term)

\subsection{Air Quality}

The Air Quality Program provides compliance assistance for all nonradiological air emission sources at SNL/CA. Program staff review all directives, laws, and regulations relevant to air emissions for applicability to the site. This program manages the air permit process, from the initial steps of preparing permit applications through implementation of permit conditions and annual renewals. The Air Quality Program is responsible for evaluating proposed projects, assessing chemical use, and assessing emissions of all criteria pollutants and toxic air contaminants.

The Air Quality Program assists the site in complying with the Clean Air Act, California Air Resources Board (CARB) regulations, and local Bay Area Air Quality Management District (BAAQMD) regulations. 


\subsection{Environmental Monitoring}

The Environmental Monitoring Program routinely monitors wastewater, storm water, and groundwater systems at SNL/CA to assess the effect of site operations on the public and local environment. Storm water is evaluated for general water quality, and for non-radiological and radiological constituents. Wastewater effluent resulting from site operations is monitored for non-radiological constituents. Liquid effluent control systems are operated and maintained by the program to capture wastewater from laboratory activities for analysis prior to release to the sanitary sewer. Groundwater is sampled and analyzed for non-radiological and radiological constituents to assess the extent of groundwater contamination from past operations. In addition, monitoring of external radiation at the site perimeter is conducted using thermo luminescent dosimeters. Comparisons are made of site data to offsite dose rates. The program also conducts project specific soil sampling to assess potential soil contamination from past or current operations and implements restoration activities, as needed.

The Environmental Monitoring Program assists the site in complying with federal requirements (Clean Water Act, National Emission Standards for Hazardous Air Pollutants Rule for Radionuclides); state of California requirements (Porter-Cologne Water Quality Act); and state and local permits for storm water and wastewater discharges.

\subsection{Environmental Planning and Ecology}

The Environmental Planning and Ecology Program provides oversight for ecological resource management, site-wide National Environmental Policy Act (NEPA) review, and cultural and historic resource reviews. The program coordinates and oversees wildlife, vegetation, and historic building surveys; prepares routine environmental reports that cross over multiple program areas; and implements the NEPA process.

The Environmental Planning and Ecology Program assists the site in complying with the Endangered Species Act; Migratory Bird Treaty Act; California Endangered Species Act; Federal Insecticide, Fungicide, and Rodenticide Act (FIFRA), as it applies to wildlife and habitat; National Historic Preservation Act; NEPA; DOE NEPA Implementing Procedures; DOE Order 231.1 Environment, Safety, and Health Reporting; and Executive Order 11990 Protection of Wetlands.

\subsection{Hazardous Materials Management}

The Hazardous Materials Management Program is responsible for tracking hazardous materials (chemical and biological), managing the Material Safety Data Sheets (MSDS) library, providing MSDS information to site personnel, and for regulatory compliance reporting required under various hazardous materials regulations. The program is also responsible for supporting hazardous material safety and information requirements site-wide.

The Hazardous Materials Management Program assists the site in complying with the Emergency Planning and Community Right-to-Know Act and California Right-to-Know 
(EPCRA) regulations. The Hazard Communication/Lab Standard of the Occupational Safety and Health Administration is also key to program operations.

\subsection{Pollution Prevention and Waste Minimization}

The Pollution Prevention and Waste Minimization Program promotes the elimination or reduction of all types of wastes generated at SNL/CA. Program staff work closely with Facilities organizations to establish routine and project specific recycling programs. The program provides guidance for resource and energy conservation and assists in identifying recycled-content products for use throughout the site. Pollution Prevention and Waste Minimization also implements the universal waste program to ensure proper handling and disposal of low-hazard waste such as consumer electronics, mercury wastes, cathode ray tubes, and fluorescent tubes.

The Pollution Prevention and Waste Minimization Program assists the site in complying with the Pollution Prevention Act; Resource Conservation and Recovery Act (RCRA), California Hazardous Waste Source Reduction and Management Review Act; and numerous executive and DOE orders. A complete list of orders is provided in the Pollution Prevention and Waste Minimization Program Annual Report (Appendix B).

\subsection{Waste Management}

The Waste Management Program manages hazardous, radioactive, and mixed wastes generated by SNL/CA operations. Program personnel collect waste from the point of generation and transfer it to either the Hazardous Waste Storage Facility or the Radioactive Waste Storage Facility for storage, consolidation, and packaging. The program establishes and maintains contracts for offsite treatment and disposal of wastes, manages the RCRA permit process and implements conditions of the permit, conducts process knowledge evaluations to characterize waste types generated from specific operations, and provides training to all SNL/CA waste generators.

The Waste Management Program assists the site in complying with Federal requirements (RCRA, Toxic Substances Control Act, Federal Facilities Compliance Act, FIFRA); State of California requirements (Hazardous Waste Control Law, Medical Waste Management Act); DOE orders for radioactive waste management and packaging and transportation of waste; and the RCRA Part B Permit for SNL/CA. 


\section{Legal and Other Requirements}

SNL/CA is subject to many federal, state, and local environmental laws, regulations, and requirements. Sandia operations are also subject to DOE directives identified in Sandia Corporation's contract with DOE for management and operation of Sandia National Laboratories. Sandia is committed to managing all activities in accordance with these policies, directives, and processes within the boundaries of the prime contract, applicable laws, DOE and corporate directives, and best management practices. As part of our mission, we strive to serve our customers by anticipating their needs, meeting their requirements, and exceeding their expectations (SNL 2008a). DOE and Sandia establish an annual performance evaluation plan that outlines the expectations for performance.

\subsection{Current Requirements}

Environmental requirements applicable to SNL/CA operations are detailed in annual program reports prepared for each environmental program area (Appendix B). Table 7 provides a list of primary environmental requirements that are applicable to each environmental aspect. In addition to the requirements listed in Table 8, DOE and Sandia establish a set of operational expectations each year. DOE's expectations of Sandia for 2009 can be found in the Fiscal Year 2009 Performance Evaluation Plan for Sandia Corporation in the Operation and Management of Sandia National Laboratories at https://rproxy.sandia.gov/my/authsec/portal/ilms/default/ customer/requirements/satisfaction/laboratoryPerformanceEvaluation. The 2009 Performance Evaluation Plan includes performance measures for environmental compliance.

Table 7 Primary Environmental Requirements Associated with Environmental Aspects

\begin{tabular}{ll}
\hline Environmental Aspect & Environmental Requirement \\
\hline & CPR 400.1.1 ES\&H Manual and Supplements \\
& DOE Order 450.1, Environmental Protection Program \\
& 33 United States Code (USC) §1251, Clean Water Act \\
& 40 Code of Federal Regulations (CFR) 112, Oil Pollution Prevention \\
& 40 CFR 122 - 125, National Pollutant Discharge Elimination System \\
Water discharges & 40 CFR 129 Toxic Pollutant Effluent Standards and Prohibitions \\
(significant aspect) & 40 CFR 403 General Pretreatment Regulations for Existing and New Sources of Pollution \\
& T0 CFR 433 Metal Finishing Point Source Category \\
& Title 23 California Code of Regulations (CCR), Division 3 \\
& Title 17 CCR Public Health \\
& California Health and Safety Code (H\&S Code), Division 20, Chapter 6.6, California Safe \\
& Drinking Water and Toxic Enforcement Act of 1986, Proposition 65
\end{tabular}


EMS Program Manual

April 2009

\begin{tabular}{|c|c|}
\hline Environmental Aspect & Environmental Requirement \\
\hline $\begin{array}{l}\text { Air emissions } \\
\text { (significant aspect) }\end{array}$ & $\begin{array}{l}\text { CPR 400.1.1 ES\&H Manual and Supplements } \\
\text { DOE Order 450.1, Environmental Protection Program } \\
\text { Clean Air Act, 42 USC § } 7401 \\
\text { 40 CFR 61, National Emissions Standards for Hazardous Air Pollutants, Subpart H } \\
\text { California H\&S Code, Division } 26 \\
\text { California Clean Air Act } \\
\text { California Air Resources Board Regulations } \\
\text { Bay Area Air Quality Management District Regulations } \\
\text { Executive Order (EO) 12843, Procurement Requirements and Policies for Federal Agencies } \\
\text { for Ozone-Depleting Substances } \\
\text { California H\&S Code, Division } 25.5 \S 38500 \text { et. seq. California Global Warming Solutions } \\
\text { Act of } 2006\end{array}$ \\
\hline $\begin{array}{l}\text { Land use } \\
\text { (significant aspect) }\end{array}$ & 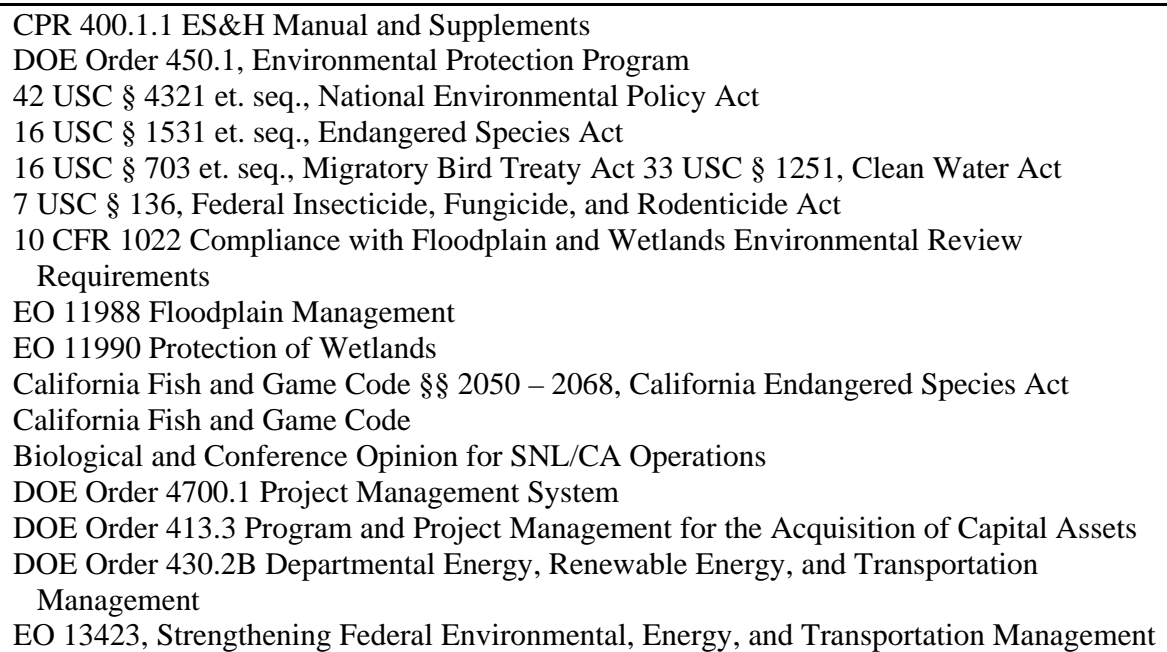 \\
\hline $\begin{array}{l}\text { General transportation } \\
\text { (significant aspect) }\end{array}$ & $\begin{array}{l}\text { DOE Order 450.1, Environmental Protection Program } \\
\text { Energy Policy Act of } 2005 \\
\text { EO 13423, Strengthening Federal Environmental, Energy, and Transportation Management }\end{array}$ \\
\hline $\begin{array}{l}\text { Hazardous waste } \\
\text { (significant aspect) }\end{array}$ & $\begin{array}{l}\text { CPR 400.1.1 ES\&H Manual and Supplements } \\
\text { GN470075 Guidelines for Waste Generators at SNL/CA } \\
\text { DOE Order 450.1, Environmental Protection Program } \\
42 \text { USC § } 6901 \text { et. seq., RCRA } \\
42 \text { USC } ~ 6961 \text {, Federal Facility Compliance Act } \\
40 \text { CFR } 239 \text { - 299, RCRA Implementing Regulations } \\
29 \text { CFR } 1910.120 \text {, Hazard Communication Standard } \\
\text { California H\&S Code, Division 20, Chapter 6.5, California Hazardous Waste Control Law } \\
\text { California H\&S Code, Division 104, Part 14, §§ } 117600 \text {-118360, California Medical Waste } \\
\text { Management Act } \\
\text { Title } 22 \text { CCR California Implementing Regulations for RCRA } \\
\text { 42 USC § } 13101 \text { et. seq., Pollution Prevention Act of } 1990 \\
\text { EO 13423, Strengthening Federal Environmental, Energy, and Transportation Management } \\
\text { California Hazardous Waste Source Reduction and Management Review Act of } 1989 \\
\text { California H\&S Code, Division 20, Chapter 6.5, Hazardous Waste Control } \\
\text { California H\&S Code, Division 20, Chapter 6.5, Waste Minimization Certification } \\
\text { 15 USC § 2601 et. seq., Toxic Substances Control Act } \\
\text { SNL/CA Hazardous Waste Facility Permit } \\
\text { SNL/CA Part B Hazardous Waste Operation Plan }\end{array}$ \\
\hline
\end{tabular}




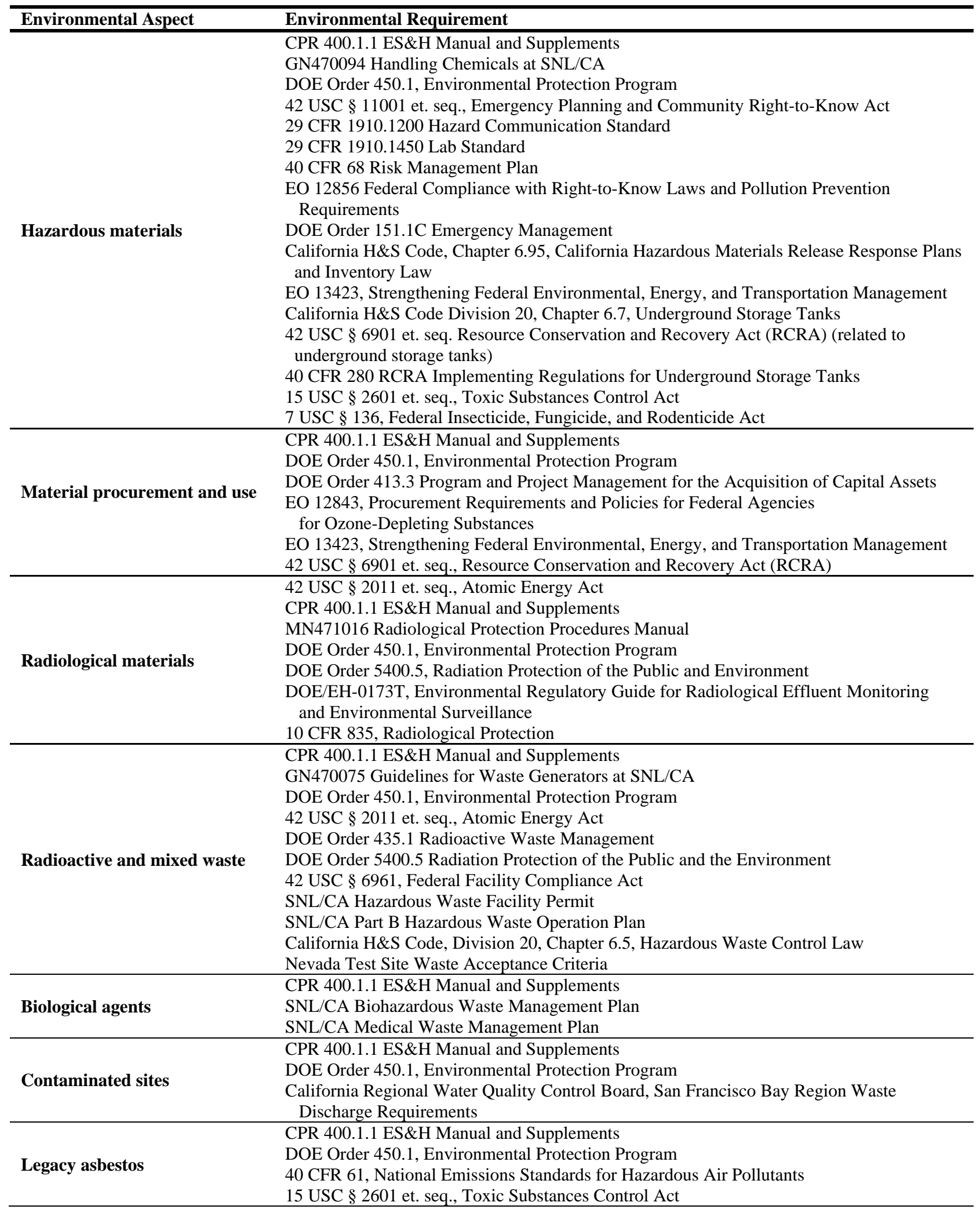




\begin{tabular}{|c|c|}
\hline Environmental Aspect & Environmental Requirement \\
\hline Solid waste (non-hazardous) & $\begin{array}{l}\text { DOE Order 450.1, Environmental Protection Program } \\
42 \text { USC } \S 13101 \text { et. seq., Pollution Prevention Act of } 1990 \\
\text { EO 13423, Strengthening Federal Environmental, Energy, and Transportation Management } \\
\text { California Public Resources Code } \S 42961.5 \text {, Waste Tire Manifest Program } \\
\text { California H\&S Code Division 20, Chapter 6.5, § 25211, Appliance Recycling } \\
\text { Title } 22 \text { CCR Division 4.5, Chapter 16, Recyclable Materials } \\
\text { Title } 22 \text { CCR, Division 4.5, Chapter 23, Universal Waste Management } \\
\text { Title } 22 \text { CCR, 66273, California Electronic Waste Recycling Act } \\
\text { California Public Resources Code } \S \S 42490-42499 \text {, Cell Phone Recycling Act }\end{array}$ \\
\hline $\begin{array}{l}\text { Hazardous material } \\
\text { transportation }\end{array}$ & $\begin{array}{l}\text { CPR 400.1.1 ES\&H Manual and Supplements } \\
\text { DOE Order 450.1, Environmental Protection Program } \\
\text { DOE Order 460.1B Packaging and Transportation Safety } \\
\text { 49 CFR - Transportation } \\
\text { SNL/CA Transportation Safety Document } \\
\text { SNL/CA Transportation Security Plan } \\
\end{array}$ \\
\hline Natural gas use & $\begin{array}{l}\text { DOE Order 450.1, Environmental Protection Program } \\
\text { Energy Policy Act of } 2005 \\
\text { DOE Order 430.2B Departmental Energy, Renewable Energy, and Transportation } \\
\text { Management } \\
\text { EO 13423, Strengthening Federal Environmental, Energy, and Transportation Management }\end{array}$ \\
\hline Water use & $\begin{array}{l}\text { DOE Order 450.1, Environmental Protection Program } \\
\text { DOE Order 430.2B Departmental Energy, Renewable Energy, and Transportation } \\
\text { Management } \\
\text { EO 13423, Strengthening Federal Environmental, Energy, and Transportation Management }\end{array}$ \\
\hline Electricity use & $\begin{array}{l}\text { DOE Order 450.1, Environmental Protection Program } \\
\text { Energy Policy Act of } 2005 \\
\text { DOE Order 430.2B Departmental Energy, Renewable Energy, and Transportation } \\
\text { Management } \\
\text { EO 13423, Strengthening Federal Environmental, Energy, and Transportation Management }\end{array}$ \\
\hline Fire (emergency aspect) & $\begin{array}{l}\text { CPR 400.1.1 ES\&H Manual and Supplements } \\
\text { DOE Order 151.1C Emergency Management }\end{array}$ \\
\hline $\begin{array}{l}\text { Earthquake (emergency } \\
\text { aspect) }\end{array}$ & $\begin{array}{l}\text { CPR 400.1.1 ES\&H Manual and Supplements } \\
\text { DOE Order 151.1C Emergency Management }\end{array}$ \\
\hline
\end{tabular}

\subsection{Monitoring Requirements}

The process for monitoring ES\&H requirements is identified in Administrative Procedure (AOP 04-02 (SNL 2007b). At the corporate level, Sandia monitors DOE directives, DOE Acquisition Regulation activity, Federal Register, and federal, state, and local government publications for regulatory changes and issues applicable to SNL operations. New requirements are communicated to the workforce through established internal mechanisms and incorporated into the Sandia ES\&H Manual, a comprehensive document that guides the workforce through the compliance process (SNL 2009a). New requirements are then incorporated into facility- and operation-specific work planning and control documents.

Environmental subject matter experts (SMEs) at SNL/CA monitor state and local issues to augment corporate monitoring. Subscriptions to electronic and paper publications and interactions with regulators are two primary ways that SNL/CA's SMEs stay current on environmental requirements. SNL/CA SMEs work directly with regulating agencies to obtain information on new and changing requirements well in advance of requirements becoming effective. Such advance notice allows the SNL/CA EMS Core Team to identify resources and implement effective and cost efficient processes for compliance. Environmental staff members 
attend conferences routinely and participate as members of environmental organizations that publish newsletters and discipline-specific informational materials. Environmental consultants that support Sandia's staff also keep abreast of regulatory changes that may affect their clients.

SMEs at both SNL/CA and SNL/NM interact regularly with their DOE counterparts and regulators. Through these customer and stakeholder interactions, some changes (i.e., executive orders and policies, applicable litigation results, best management practices, etc.) may be identified that are not incorporated into Sandia's Management and Operating Contract (M\&O Contract) as formal requirements. Although such changes are not necessarily contract requirements, where appropriate, they are incorporated into the EMS and implemented through functional environmental programs. However, because this process is informal, some changes that may be appropriate may not be captured.

\subsection{Recent Modifications to Requirements}

Table 8 summarizes information from the annual program reports pertaining to new and modified environmental requirements that were implemented in 2008/2009 or are pending.

Table 8 New and Modified Environmental Requirements, 2008/2009

\begin{tabular}{|c|c|c|c|c|}
\hline Requirement Summary & Effective Date & Driver & $\begin{array}{l}\text { Program } \\
\text { Modification }\end{array}$ & $\begin{array}{l}\text { Environmental } \\
\text { Aspect }\end{array}$ \\
\hline $\begin{array}{l}\text { Update - DOE Order 450.1A, } \\
\text { Environmental Protection Program } \\
\text { Outlines the basic strategy for } \\
\text { environmental compliance at DOE } \\
\text { facilities }\end{array}$ & June 4, 2008 & DOE Order 450.1A & $\begin{array}{l}\text { Incorporated into } \\
\text { EMS Program }\end{array}$ & All \\
\hline $\begin{array}{l}\text { DOE Order 430.2B } \\
\text { Departmental Energy, renewable } \\
\text { Energy and Transportation } \\
\text { Management - Requirements for } \\
\text { efficient and effective management or } \\
\text { energy, water, and vehicle fleets at } \\
\text { DOE facilities }\end{array}$ & $\begin{array}{l}\text { February 27, } \\
2008\end{array}$ & DOE Order 430.2B & $\begin{array}{l}\text { Objectives and targets } \\
\text { for energy use, water } \\
\text { use, and general } \\
\text { transportation } \\
\text { incorporated into } \\
\text { EMS Program }\end{array}$ & $\begin{array}{l}\text { Water use, } \\
\text { general } \\
\text { transportation, } \\
\text { electricity use, } \\
\text { natural gas use, } \\
\text { land use, }\end{array}$ \\
\hline $\begin{array}{l}\text { Authorization from US Army Corp of } \\
\text { Engineers for remaining tasks under } \\
\text { the Arroyo Seco Improvement } \\
\text { Program }\end{array}$ & $\begin{array}{l}\text { September } \\
2008\end{array}$ & Clean Water Act & $\begin{array}{l}\text { SNL/CA must initiate } \\
\text { these tasks over next } \\
\text { ten years }\end{array}$ & Land use \\
\hline $\begin{array}{l}\text { Tentative Order for updated } \\
\text { Construction Activities General } \\
\text { Permit for hydromodification project } \\
\text { requirements, sampling requirements, } \\
\text { effluent triggers / limits, notice of } \\
\text { intent / storm water pollution } \\
\text { prevention plan public review process }\end{array}$ & $\begin{array}{l}\text { Expected in } \\
2009\end{array}$ & Clean Water Act & $\begin{array}{l}\text { SNL/CA will } \\
\text { implement as outlined } \\
\text { in the Tentative Order }\end{array}$ & Water discharges \\
\hline $\begin{array}{l}\text { Update - Electronic Waste Recycling } \\
\text { Act of } 2003 \text { to include electronic } \\
\text { devices with screens less than } 4 \\
\text { inches }\end{array}$ & June 2008 & $\begin{array}{l}\text { CCR Title 22, Div. } \\
4.5 \text {, Chapter } 11\end{array}$ & $\begin{array}{l}\text { Incorporated into } \\
\text { universal waste } \\
\text { recycling program }\end{array}$ & Hazardous waste \\
\hline
\end{tabular}




\begin{tabular}{|c|c|c|c|c|}
\hline Requirement Summary & Effective Date & Driver & $\begin{array}{l}\text { Program } \\
\text { Modification } \\
\end{array}$ & $\begin{array}{l}\text { Environmental } \\
\text { Aspect }\end{array}$ \\
\hline $\begin{array}{l}\text { CARB regulation limits emissions } \\
\text { from off-road diesel vehicles with } \\
\text { engines equal to or greater than } 25 \mathrm{hp}\end{array}$ & March 1, 2009 & $\begin{array}{l}\text { CCR Title 13, } \\
\text { Section } 2449\end{array}$ & $\begin{array}{l}\text { SNL/CA must adopt } \\
\text { idling policy by } \\
\text { March 1, 2009, report } \\
\text { inventory by April 1, } \\
\text { 2009, and reduce } \\
\text { emissions from off- } \\
\text { road diesel vehicles } \\
\text { starting March 1, } \\
2010\end{array}$ & Air emissions \\
\hline $\begin{array}{l}\text { CARB regulation limits emissions } \\
\text { from portable diesel equipment with } \\
\text { engines equal to or greater than } 50 \\
\text { hp. }\end{array}$ & $\begin{array}{l}\text { January 1, } \\
2010\end{array}$ & $\begin{array}{l}\text { CCR Title 17, } \\
\text { Section } 9316\end{array}$ & $\begin{array}{l}\text { SNL/CA must not } \\
\text { purchase Tier } 0 \\
\text { engines starting } \\
\text { January } 1,2010 \text { and } \\
\text { must reduce emissions } \\
\text { from existing engines } \\
\text { starting January 1, } \\
2013\end{array}$ & Air emissions \\
\hline $\begin{array}{l}\text { CARB regulation limits emissions } \\
\text { from on-road diesel trucks with } \\
\text { GVWR greater than } 14,000 \text { pounds. }\end{array}$ & $\begin{array}{l}\text { January 31, } \\
2010\end{array}$ & $\begin{array}{l}\text { CCR Title 13, } \\
\text { Section } 2025\end{array}$ & $\begin{array}{l}\text { SNL/CA must report } \\
\text { inventory by January } \\
31,2010 \text { and reduce } \\
\text { emissions from on- } \\
\text { road trucks starting } \\
\text { January } 1,2011 \\
\end{array}$ & Air emissions \\
\hline $\begin{array}{l}\text { CARB Large Spark Ignition Engine } \\
\text { regulation limits emissions from } \\
\text { gasoline forklifts. }\end{array}$ & $\begin{array}{l}\text { January 1, } \\
2009\end{array}$ & $\begin{array}{l}\text { CCR Title 13, } \\
\text { Sections 2430, } \\
\text { 2431, 2438, } 2775\end{array}$ & $\begin{array}{l}\text { SNL/CA must reduce } \\
\text { emissions from } \\
\text { forklifts starting } \\
\text { January } 1,2011\end{array}$ & Air emissions \\
\hline $\begin{array}{l}\text { BAAQMD requires results of annual } \\
\text { Leak Test on gasoline dispensing } \\
\text { facility to be submitted to agency }\end{array}$ & January 2008 & $\begin{array}{l}\text { BAAQMD } \\
\text { Regulation 8, Rule } \\
7 \text { and BAAQMD } \\
\text { Permit condition } \\
\end{array}$ & $\begin{array}{l}\text { SNL/CA must submit } \\
\text { results of Leak Test } \\
\text { within } 20 \text { days of test } \\
\text { date }\end{array}$ & Air emissions \\
\hline $\begin{array}{l}\text { BAAQMD regulation requires } \\
\text { increase measures to control } \\
\text { emissions from boilers rated between } \\
2 \mathrm{MMBtu} / \mathrm{hr} \text { and } 10 \mathrm{MMBtu} / \mathrm{hr} /\end{array}$ & $\begin{array}{l}\text { January 1, } \\
2009\end{array}$ & $\begin{array}{l}\text { BAAQMD } \\
\text { Regulation 9, Rule } \\
7\end{array}$ & $\begin{array}{l}\text { SNL/CA must } \\
\text { perform annual } \\
\text { inspections/tune-ups } \\
\text { starting 2009; install } \\
\text { insulation by January } \\
\text { 1, 2010; and meet } \\
\text { stack temperature and } \\
\text { emission requirements } \\
\text { starting January 1, } \\
2011\end{array}$ & Air emissions \\
\hline
\end{tabular}




\section{Operational Control}

Sandia maintains a Corporate Policy System that reflects the requirements of its contract with DOE and is consistent with the intent of Lockheed Martin Corporate Policy (Sandia's parent company). The Corporate Policy System governs all Sandia operations (SNL 2009f). It is part of Sandia’s Integrated Laboratory Management System, and managed by the Corporate Policy \& Lab Performance Evaluation Department. Operational controls for the site are further enhanced with division and project-specific technical work documents.

\subsection{Corporate Controls}

The Corporate Policy System contains nine policy areas and three levels within each area. The nine policy areas include corporate governance, ES\&H, facilities, finance, human resources management, information management, integrated safeguards and security, mission execution, and supply chain management. The policy system levels are: Level 1 Corporate Policies; Level 2 Corporate Processes; and Level 3 Corporate Procedures. All policies, processes, and procedures require review at least every three years.

The Corporate Policy System was rolled-out in April 2009 and replaces the Corporate Business Rules System. The ES\&H Policy Area is available through the corporate system but the structure of its policy, processes, and procedures will not change to the new format until September 2009.

Many of the Corporate Policy System requirements support the SNL/CA EMS Program. References to specific corporate policy system requirements are made throughout this manual when appropriate.

\subsubsection{ES\&H Manual and Supplements (CPR400.1.1)}

The primary corporate control document for environmental requirements is the ES\&H Manual. It provides basic operational controls for the Sandia workforce (SNL 2009a) at all Sandia locations. It describes the basics of Sandia’s ES\&H Program. It identifies the boundaries of the program, describes how requirements flow down to Sandia organizations, and defines ES\&H roles and responsibilities. The ES\&H Manual is a compilation of process requirements and general procedures for complying with ES\&H laws, regulations, DOE Orders, and Sandia requirements. The ES\&H Manual is supplemented by site-specific process requirements when needed to address state and local requirements that are applicable at SNL/CA.

\subsection{Local Controls}

SNL/CA maintains a variety of operational controls that are site specific. These include technical work documents, an ES\&H, Facilities, and Security Interdisciplinary Team, environmental permits and compliance documents, and contract specifications. 
The process used at SNL/CA for work planning and control is depicted in Figure $16^{1}$. The process follows standard Sandia ISMS/EMS steps to plan work, analyze hazards, control hazards, perform work, and improve. Relevant significant environmental aspects for specific activities are determined during analyses of hazards.

\subsubsection{Technical Work Documents}

Technical work documents are required for all operations. The procedure for preparing and maintaining technical work documents is identified in Chapter 21 of the ES\&H Manual. The initial step in identifying operational controls is accomplished through Sandia's PHS process. The PHS is an online tool used to identify potential hazards associated with new and continuing activities. Through execution of the PHS tool, technical work documents, training, and personal protective equipment are identified to control safety conditions and environmental releases. All active PHSs are reviewed and updated annually. At SNL/CA, the center ES\&H coordinators assist the site workforce with preparation and update of PHSs. The PHS database is available online to all Sandia workers at http://info.sandia.gov/esh/phs/.

Technical work documents are used to define administrative and engineered controls required to address the hazards identified through the PHS. Technical work documents include operating procedures, standard operating procedures, safe work permits, and radiological work permits. These documents are updated every one to five years, or more frequently as needed. Technical work documents are maintained in an online database that can be found at https://sierrarf.ran.sandia.gov/eshdoc.nsf.

\subsubsection{Interdisciplinary Team Process}

The Interdisciplinary Team (IDT) process is a review process for new and changing projects at SNL/CA. IDT reviews occur during project planning so that environmental requirements and controls can be identified early and incorporated into project schedules. The IDT process has been used for more than ten years and is recognized by internal and DOE stakeholders as a successful best management practice and operational control mechanism. Additional information about IDT is provided in Chapter 14.

\footnotetext{
${ }^{1}$ The work planning and control process is being updated. Implementation of the updated process must be initiated by June 30, 2009. Updates are expected to enhance the existing process to create efficiencies and effectiveness in planning and controlling work. The methodology outlined in Figure 16 will not change substantially.
} 


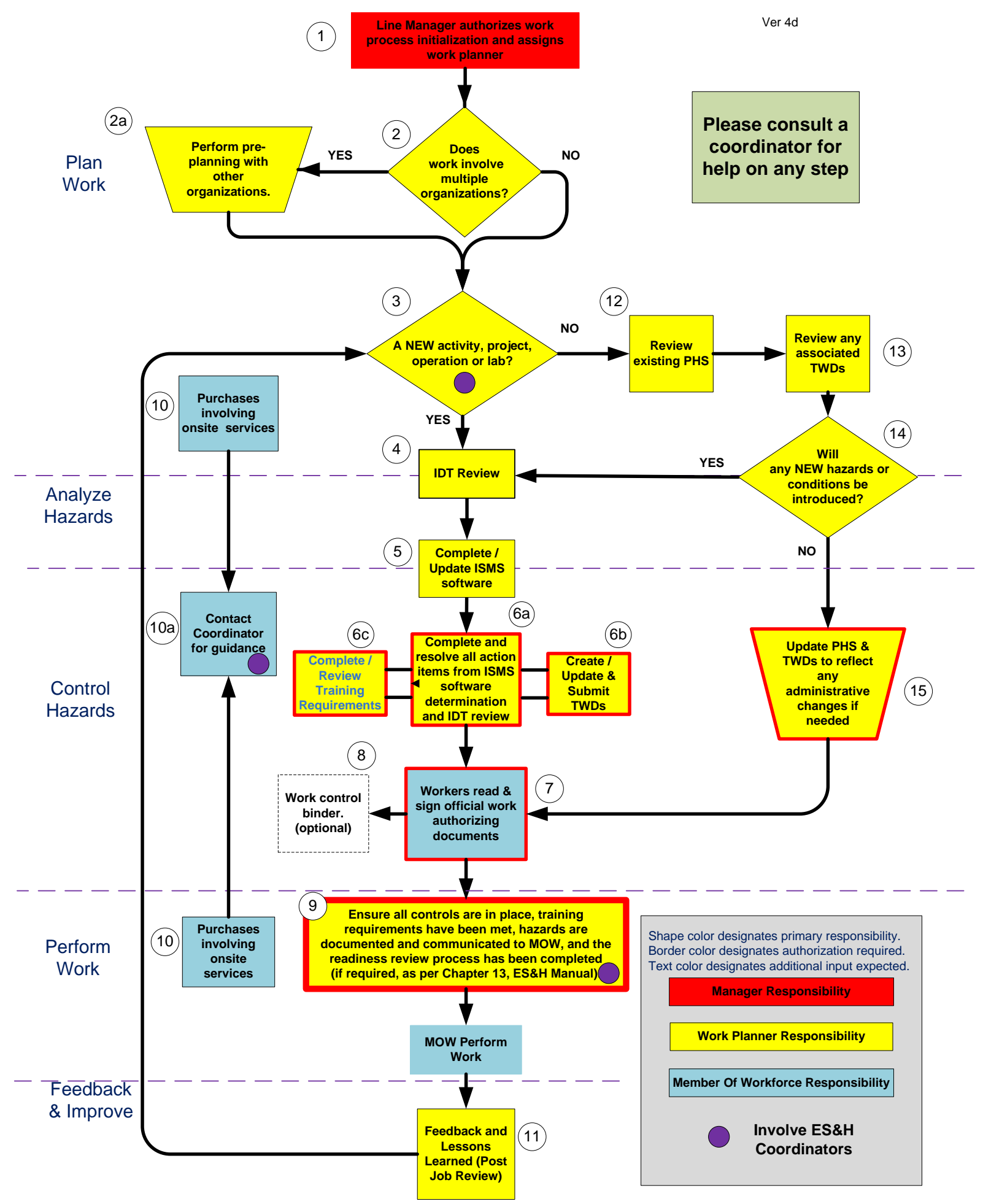

Figure 16 SNC/CA ES\&H Review Process 


\subsubsection{Environmental Permits and Compliance Documents}

Environmental permits and compliance documents function as activity-specific operational controls. They provide conditions under which the SNL/CA site may operate to meet federal, state, and local environmental regulatory requirements. Table 10 provides a list of the permits and documents valid in 2009. The individual environmental program annual reports provide additional information about each type of permit or compliance document (Appendix B).

Table 9 Environmental Permits and Compliance Documents, 2009

\begin{tabular}{|c|c|c|c|}
\hline Type & Description & Statute / Regulation & Agency /Authority \\
\hline Air & $\begin{array}{l}\text { Permit to Operate emission } \\
\text { sources ( } 15 \text { sources for } \\
2008 / 2009)\end{array}$ & Clean Air Act & BAAQMD \\
\hline $\begin{array}{l}\text { Environmental } \\
\text { restoration }\end{array}$ & $\begin{array}{l}\text { Site Clean-up Order No. 89- } \\
184\end{array}$ & California Water Code & $\begin{array}{l}\text { Regional Water Quality } \\
\text { Control Board, San Francisco } \\
\text { Bay }\end{array}$ \\
\hline $\begin{array}{l}\text { Hazardous } \\
\text { materials }\end{array}$ & $\begin{array}{l}\text { Business Plan Permit to } \\
\text { Operate }\end{array}$ & $\begin{array}{l}\text { California Health and Safety } \\
\text { Code }\end{array}$ & $\begin{array}{l}\text { Alameda County } \\
\text { Environmental Health } \\
\text { Department }\end{array}$ \\
\hline Hazardous waste & $\begin{array}{l}\text { RCRA Hazardous Waste } \\
\text { Facility Permit }\end{array}$ & RCRA & $\begin{array}{l}\text { California Department of } \\
\text { Toxic Substances Control }\end{array}$ \\
\hline Hazardous waste & Permit by Rule & RCRA & $\begin{array}{l}\text { Alameda County } \\
\text { Environmental Health } \\
\text { Department } \\
\end{array}$ \\
\hline Hazardous waste & $\begin{array}{l}\text { Conditionally Authorized } \\
\text { Permit to Operate }\end{array}$ & $\begin{array}{l}\text { California Health and Safety } \\
\text { Code }\end{array}$ & $\begin{array}{l}\text { Alameda County } \\
\text { Environmental Health } \\
\text { Department } \\
\end{array}$ \\
\hline Medical waste & $\begin{array}{l}\text { Small Quantity Generator with } \\
\text { Onsite Treatment }\end{array}$ & $\begin{array}{l}\text { California Health and Safety } \\
\text { Code }\end{array}$ & $\begin{array}{l}\text { Alameda County } \\
\text { Environmental Health } \\
\text { Department }\end{array}$ \\
\hline Medical waste & $\begin{array}{l}\text { Small Quantity Generator } \\
\text { without Onsite Treatment }\end{array}$ & $\begin{array}{l}\text { California Health and Safety } \\
\text { Code }\end{array}$ & $\begin{array}{l}\text { Alameda County } \\
\text { Environmental Health } \\
\text { Department }\end{array}$ \\
\hline Wastewater & Wastewater Discharge Permit & Clean Water Act & $\begin{array}{l}\text { City of Livermore Water } \\
\text { Reclamation Plant }\end{array}$ \\
\hline Storm water & $\begin{array}{l}\text { State of California General } \\
\text { Industrial Permit }\end{array}$ & Clean Water Act & $\begin{array}{l}\text { State of California Water } \\
\text { Resources Control Board }\end{array}$ \\
\hline $\begin{array}{l}\text { Jurisdictional } \\
\text { waters of the U.S. }\end{array}$ & $\begin{array}{l}\text { Channel improvements under } \\
\text { the Arroyo Seco Improvement } \\
\text { Program }\end{array}$ & Clean Water Act & Army Corp of Engineers \\
\hline $\begin{array}{l}\text { Underground } \\
\text { storage tank }\end{array}$ & Permit to Operate & $\begin{array}{l}\text { Resource Conservation and } \\
\text { Recovery Act and California } \\
\text { Health and Safety Code }\end{array}$ & $\begin{array}{l}\text { Alameda County } \\
\text { Environmental Health } \\
\text { Department }\end{array}$ \\
\hline $\begin{array}{l}\text { Aboveground } \\
\text { storage tanks }\end{array}$ & Storage statement & $\begin{array}{l}\text { Aboveground Petroleum } \\
\text { Storage Act }\end{array}$ & $\begin{array}{l}\text { State of California Water } \\
\text { Resources Control Board }\end{array}$ \\
\hline $\begin{array}{l}\text { Environmental } \\
\text { assessment }\end{array}$ & $\begin{array}{l}\text { Final Site-wide Environmental } \\
\text { Assessment of the SNL/CA }\end{array}$ & NEPA & DOE \\
\hline $\begin{array}{l}\text { Biological } \\
\text { resources }\end{array}$ & $\begin{array}{l}\text { Biological and Conference } \\
\text { Opinion for SNL/CA }\end{array}$ & Endangered Species Act & U.S. Fish and Wildlife Service \\
\hline Universal waste & Generator statement & $\begin{array}{l}\text { California Electronic Waste } \\
\text { Recycling Act, } \\
22 \text { CCR § } 66273\end{array}$ & $\begin{array}{l}\text { California Department of } \\
\text { Toxic Substances Control }\end{array}$ \\
\hline
\end{tabular}




\subsubsection{Contract Specifications}

SNL/CA's contract specifications function as operational controls for contractor-directed work activities. The specifications include requirements for contractors to apply environmental controls in all appropriate work activities to maintain regulatory compliance and support environmental stewardship efforts at SNL/CA. Contractors are also required to report to $\mathrm{SNL} / \mathrm{CA}$ on their efforts in waste reduction, recycling, and reuse of materials.

SNL/CA implemented an environmental specification that will consolidate all environmental requirements applicable for construction activities into one document. An environmental permit is also pending implementation that will be included as part of the bid package to identify check points and contacts for various activities. The permit is expected to be implemented by June 2009.

Efforts are also underway to identify environmental concerns for small value service / repair contracts. In October 2008, SNL/CA developed an environmental checklist to collect information during the procurement process from service / repair contractors. Identification of environmental concerns will be part of a new SNL/CA Work Planning and Control Procedure expected to be implemented by June 30, 2009. 


\section{Document Control}

\subsection{Corporate Documents}

The Information Management Policy Area (IM 100) identifies the process and procedures for managing and protecting Sandia information (SNL 2009c). The official version of all corporate policies, processes, and procedures is the electronic version maintained on the Sandia Restricted Network. These documents are disseminated to the workforce exclusively through the Corporate Policy System. They are reviewed and updated at least every three years. Each document is assigned an Executive Policy Sponsor. Only the sponsor or their delegate can approve changes to these documents.

\subsection{Technical Work Documents}

ES\&H requirements and concerns related to activities and operations at SNL/CA are addressed through technical work documents such as operating procedures, hazard assessments, safety plans, and other similar documents. The procedure for updating and controlling technical work documents is identified in Chapter 21 of the ES\&H Manual (SNL 2009a). Technical work documents are marked with an issue identifier for version control, date of publication, review period, and due date of next issue. The most current version of technical work documents is maintained in an online database. Outdated versions are removed from the online system when new versions are issued to prevent unintended use of obsolete documents.

Safety procedures and plans contain authorized users lists. Personnel must read updated versions of technical work documents when issued and sign the authorized users list indicating their understanding and agreement to operate in accordance with new and modified procedures. Reference copies of technical work documents may be kept at the point of use at the discretion of the appropriate line manager. Line managers are responsible for establishing a process to keep printed reference documents up to date and for ensuring that personnel have reviewed appropriate procedures and signed the authorized users list before conducting operations.

To control obsolete documents at point of use, Sandia identifies five methods of document control in the ES\&H Manual, Chapter 21 (SNL 2009a). Methods range in formality from use of a formal document control center or numbered controlled copies to posting electronic copies on an internal Sandia network.

SNL/CA increased efforts to control obsolete documents at point of use in 2006 in response to an ISO audit finding. Line manager responsibilities for document control were specifically identified in the Division 8000 Work Planning and Control Procedure (AP800015). In November 2008, validation of the corrective action was conducted and found that 38 percent of documents maintained in point of use binders were obsolete. SHEAC reiterated that it is the line manager's responsibility to review document binders during routine surveillances for obsolete documents. A follow-up validation is planned for October / November 2009. 
In August 2008, SNL/CA implemented a new process to stamp obsolete documents maintained in the ES\&H Records Center as superseded. As updated documents are filed in the Records Center, outdated versions are stamped.

\subsection{Environmental Program Documents}

EMS program and other environmental program documents are controlled by the Environmental Management Department (Organization 8516). These documents are reviewed annually as part of the program assessment process outlined in Quality Assurance of Data, Documents and Select Activities of the Environmental, Safety, and Health Departments, 8516 and 8517 (Appendix C). Each program lead controls and approves changes to their documents. The department manager controls and approves changes to EMS-specific documents. Current versions are maintained in active records storage in the ES\&H Records Center, and displayed on the SNL/CA ES\&H web site. Paper copies are not distributed to the workforce.

Environmental documents of external origin (e.g. permits, regulatory authorizations, etc.) are maintained by the Environmental Management Department. Many of these documents are marked as valid for a specified period of time. Environmental program leads coordinate updates to external documents to ensure that documentation remains current. Permits and other regulatory authorizations that require posting at point of use are controlled and distributed by environmental program leads to ensure that obsolete documents are not used unintentionally. 


\section{Competence, Training, and Awareness}

Operations at SNL/CA fall within two categories, Sandia-directed and contractor-directed. The mechanisms used to ensure that the workforce is competent, trained, and aware differ depending on the category of operation. To foster general site awareness of EMS and ES\&H issues, SNL/CA routinely disseminates information through brochures, fact sheets, newsletter articles, the ES\&H website, electronic announcements, project reviews, and line assessments. Chapter 20 provides additional information on EMS communications.

\subsection{Sandia-directed Operations}

Members of the workforce involved in Sandia-directed operations are subject to the requirements of Sandia’s ES\&H Manual. These requirements apply to Sandia employees (full and part-time staff, student interns, post-doctoral appointees), contractors performing under Sandia-directed contracts, and visitors (conference and meeting attendees, visiting researchers, industry partners). Chapter 11 of the ES\&H Manual summarizes training for Sandia-directed operations. All Sandia workers and visitors are accountable and responsible for meeting applicable ES\&H requirements, including those related to training.

SNL/CA provides general EMS awareness training to the site work force through the following mechanisms.

- New-hire orientation is a one time basic orientation to ES\&H for employees and contractors performing under Sandia-directed contracts.

- ESH100 is an annual training requirement for the entire site workforce.

- ENV112CA is an annual training requirement for generators of hazardous waste at SNL/CA.

- Presentations tailored to site organizations.

\subsubsection{Employee Competence, Training, and Awareness}

It is Sandia's practice to select the best qualified individuals on the basis of demonstrated competence (HR 100.1 Acquire Talent) (SNL 2009d) and to provide opportunities for, and encourage, professional development (HR100.2 Develop the Workforce) (SNL 2009e). To support this policy, Sandia maintains a set of general corporate training courses that cover a wide range of areas such as information and physical security, business ethics and diversity, ES\&H, and general business processes. General corporate training requirements are identified at the time of hire by Sandia managers and training coordinators. Job-specific training and competencies are identified through the PHS process, by ES\&H coordinators, and by project and department managers. Training requirements are listed on a Work Authorization Form maintained for each member of the workforce. Employees review and sign the Work Authorization Form indicating their understanding of training requirements. 
Sandia maintains an online Corporate Education, Development, and Training System (CEDT System) at https://hrprod.sandia.gov/cfdocs/prod/hris/ctd/apps/cedtweb/cedtmain/index.cfm to track completion status for all corporate training requirements and to provide electronic reminders to an employee and their manager when a course is due. ES\&H Coordinators also communicate past due training statistics with Center Directors on a routine basis.

\subsubsection{Environmental Program Workforce}

Each of the six SNL/CA functional environmental program areas (Chapter 8) supporting the site's EMS Program maintain job descriptions, qualifications, and training requirements for each environmental program job position. Program leads review job descriptions, qualifications, and training requirements annually, update them as needed, and document the results of the review in annual program reports (Appendix B). The annual review and update provides an opportunity to modify training and competencies for existing environmental positions, or to identify new environmental positions, that are needed to support new or changing requirements.

EMS Program awareness and training for members of the Environmental Management Department is accomplished through monthly department meetings. Updates on current EMS Program efforts and improvements made to the program are provided to the environmental program workforce during these meetings. Additionally, EMS information specific to functional environmental programs is relayed routinely to the appropriate personnel through established and informal meetings promoted by functional program leads.

\subsubsection{Contractor Training, Awareness, and Competence}

Contractors involved in Sandia-directed operations must meet basic competencies required to perform the assigned functions. Contracting companies also provide any general certifications needed for the assignment. Sandia communicates competency requirements and required qualifications with a job statement. Contracting companies provide resumes of potentially qualified workers to Sandia for review. Sandia managers or program leads review contractor resumes and screen against the job statement, conduct interviews, and select the preferred candidate. Sandia augments contractor training for Sandia-specific requirements identified through the PHS system or by the manager directing the contractors work. Sandia-required courses are tracked in the CEDT System. Similar to Sandia employees, contracted workers and the appropriate manager are notified when courses become due.

\subsubsection{Visitor Competence, Training, and Awareness}

The level of training required for visitors is dependent on the length of stay and activity that they will perform. ES\&H training for visitors at SNL/CA is addressed in Chapter 11 of the ES\&H Manual. Sandia hosts and their managers determine the level of training required for visitors. At a minimum, visitors performing hands-on work in SNL/CA facilities receive ES\&H awareness training. Laboratory- and equipment-specific training is also provided for visiting researchers performing hands-on work at SNL/CA user facilities. For general EMS awareness, SNL/CA requires all visitors to review an ES\&H briefing card when they receive a badge and prior to entering the site. 


\subsection{Contractor-directed Operations}

Contractors performing under contractor-directed contracts are subject to standard specifications established by SNL/CA and included in the contract. Sandia identifies specialized training, credentials, or certifications required for contractors in the contract specifications. For contractor-directed operations, contractor companies must submit an Injury Illness Prevention Program and a Job Hazard Analysis for review by SNL/CA's Construction Safety Engineer. Work does not begin until these documents are approved by Sandia. A Preliminary Hazard Assessment prepared by Sandia is also included in contract documents. The hazard assessment identifies specific environmental issues, such as air quality, waste management, and storm water pollution prevention that are applicable to a specific project.

SNL/CA requires contractors to provide a project safety officer when conducting work at Sandia, and to provide written documentation that the safety officer meets the qualifications defined in the contract specifications. Additionally, specifications require contractors to maintain appropriate contractor training records on site and make available to Sandia oversight personnel upon request.

All construction projects or construction-like activities at SNL/CA are presented to the ES\&H IDT for review. The IDT process functions both as an awareness and compliance mechanism. SNL/CA executes the IDT process to identify ES\&H requirements and to disseminate EMS information to the respective SNL Project Manager. Requirements and other applicable information identified during the IDT review are provided to contractors through contract specifications and during the safety plan review process. A pre-construction conference is held to determine if the pre-work contract requirements have been met (e.g. approved safety plan, activity hazard assessment, construction site requirements, etc.). Environmental staff routinely attend pre-construction conferences to provide awareness training on topics of concern such as storm water pollution prevention, wildlife, and recycling/reuse of materials.

Sandia provides oversight throughout the length of projects. Oversight personnel identify nonconformances through deficiency notices, non-compliance notices, and safety violation notices. All non-conformance notices are tracked by Sandia and used during evaluations for contract renewals. 


\section{Environmental Monitoring and Measurement}

Each SNL/CA functional environmental program routinely monitors and measures the key characteristics of site operations that can affect the environment. Monitoring and measurement information supports our compliance requirements as well as assessment of overall progress in meeting site environmental objectives. For instance, the Environmental Monitoring and Restoration Program routinely samples and analyzes wastewater and storm water for contaminants of concern and other parameters. Data collected provide a measure of the quality of water discharges that can be used to determine if site operations meet permit conditions (compliance), or show improvement in sewer water quality (wastewater discharge objective). Program leads report the monitoring results as site metrics and publish these on the SNL/CA ES\&H webpage. Table 11 identifies the monitoring activities conducted at SNL/CA and the EMS objective that the activities support.

\section{Table 10 EMS Monitoring Activities}

\begin{tabular}{|c|c|c|}
\hline $\begin{array}{l}\text { Key Characteristics } \\
\text { of Site Operations }\end{array}$ & Monitoring Activity & Supports EMS Objective \\
\hline $\begin{array}{l}\text { Laboratory wastewater } \\
\text { discharges }\end{array}$ & $\begin{array}{l}\text { Routine sampling/analyses of sewer water; } \\
\text { weekly monitoring of continuous flow meter at } \\
\text { sewer outfall }\end{array}$ & $\begin{array}{l}\text { Minimize the volume and contamination of } \\
\text { sewer water }\end{array}$ \\
\hline $\begin{array}{l}\text { Industrial and } \\
\text { construction activities }\end{array}$ & $\begin{array}{l}\text { Routine sampling/analyses of storm water ( } 2 \\
\text { storm events per year) }\end{array}$ & $\begin{array}{l}\text { Minimize the volume and pollution of storm } \\
\text { water runoff }\end{array}$ \\
\hline $\begin{array}{l}\text { Emissions generated } \\
\text { from site operations and } \\
\text { onsite transportation }\end{array}$ & $\begin{array}{l}\text { Estimate mobile source emissions and } \\
\text { compare against baseline estimate; collect and } \\
\text { compile data on fill-ups on Spare-the-Air days }\end{array}$ & $\begin{array}{l}\text { Minimize air emissions related to operations } \\
\text { and transportation with particular emphasis on } \\
\text { Spare-the-Air days }\end{array}$ \\
\hline $\begin{array}{l}\text { Material procurement } \\
\text { and use }\end{array}$ & $\begin{array}{l}\text { Monitor annual affirmative procurement } \\
\text { purchases, EPEAT designated computer } \\
\text { purchases, and purchases of paper products }\end{array}$ & $\begin{array}{l}\text { Procure and use environmentally friendly } \\
\text { products and materials }\end{array}$ \\
\hline $\begin{array}{l}\text { Use of land where } \\
\text { sensitive wildlife and } \\
\text { habitat are present }\end{array}$ & $\begin{array}{l}\text { Annually monitor wildlife species richness; } \\
\text { annually monitor habitat improvements from } \\
\text { Arroyo Seco project and compare against } \\
\text { success criteria }\end{array}$ & Enhance the natural habitat \\
\hline Commuter site & $\begin{array}{l}\text { Periodic survey of site population on use of } \\
\text { commute alternatives }\end{array}$ & $\begin{array}{l}\text { Maximize the use of commute alternatives by } \\
\text { members of the workforce. }\end{array}$ \\
\hline $\begin{array}{l}\text { Use of fuel in onsite } \\
\text { vehicles / equipment }\end{array}$ & $\begin{array}{l}\text { Annually monitor use of liquid transportation } \\
\text { fuels }\end{array}$ & $\begin{array}{l}\text { Minimize the environmental impacts of } \\
\text { transportation. }\end{array}$ \\
\hline $\begin{array}{l}\text { Hazardous and } \\
\text { biological material use }\end{array}$ & $\begin{array}{l}\text { Annually conduct chemical inventory } \\
\text { reconciliation }\end{array}$ & $\begin{array}{l}\text { Minimize the use of hazardous material; } \\
\text { minimize the use of biological material }\end{array}$ \\
\hline $\begin{array}{l}\text { Hazardous waste } \\
\text { generation }\end{array}$ & $\begin{array}{l}\text { Continuous monitoring of quantities and types } \\
\text { of hazardous waste generated }\end{array}$ & Minimize the generation of hazardous waste \\
\hline $\begin{array}{l}\text { Radioactive and mixed } \\
\text { waste generation }\end{array}$ & $\begin{array}{l}\text { Continuous monitoring of quantities and types } \\
\text { of radioactive and mixed waste generated }\end{array}$ & $\begin{array}{l}\text { Minimize the generation of radioactive and } \\
\text { mixed waste }\end{array}$ \\
\hline Solid waste generation & $\begin{array}{l}\text { Continuous monitoring of quantities of solid } \\
\text { waste generated and quantities and types of } \\
\text { materials recycled }\end{array}$ & $\begin{array}{l}\text { Minimize the quantity of landfill waste } \\
\text { through reduced consumption and/or } \\
\text { reuse/recycling }\end{array}$ \\
\hline $\begin{array}{l}\text { Use of energy and water } \\
\text { resources }\end{array}$ & Quarterly monitoring of resources used & $\begin{array}{l}\text { Minimize site water consumption; minimize } \\
\text { site natural gas consumption; minimize site } \\
\text { electrical consumption }\end{array}$ \\
\hline $\begin{array}{l}\text { Previously contaminated } \\
\text { areas }\end{array}$ & $\begin{array}{l}\text { Quarterly monitoring of groundwater at } \\
\text { previously contaminated areas }\end{array}$ & $\begin{array}{l}\text { Minimize the environmental impacts of site } \\
\text { contaminated areas }\end{array}$ \\
\hline
\end{tabular}




\subsection{EMS Metrics}

SNL/CA uses various metrics to measure environmental affects or impacts from site operations. Additionally, SNL/CA established metrics to measure general environmental management and awareness. Table 12 provides a list of site EMS metrics. Graphical representation of each metric is displayed on the SNL/CA ES\&H website at http://surf.ran.sandia.gov/centers/8500/esh/CAEnvMgmt/metrics.

Table 11 List of EMS Metrics

\begin{tabular}{ll}
\hline Impact Metrics & EMS Management Metrics \\
\hline Mobile source emissions & Published communications \\
\hline Fueling operations on Spare-the-Air days & Outreach activities \\
\hline Wildlife species diversity & Environmental awareness \\
\hline Energy use & Environmental violations, findings, DOE occurrences \\
\hline Sewer flow & IDT reviews of site projects and activities \\
\hline Sewer water contamination & NEPA reviews \\
\hline Storm water system controls & \\
\hline Water use & \\
\hline Site chemical inventory & \\
\hline Chemical inventory reconcilliation & \\
\hline Gas cylinder inventory & \\
\hline Hazardous waste & \\
\hline Hazardous waste chemical spills & \\
\hline Environmentally preferred procurement & \\
\hline Randfill waste & \\
\hline Arroyo Seco Improvement Program plant survival \\
\hline
\end{tabular}




\section{Evaluating Compliance with Environmental Requirements}

SNL/CA evaluates compliance with all environmental requirements through the IDT process, self-assessments, and audits.

\subsection{IDT Process}

The IDT process is used to review SNL/CA projects early in the planning stages and to provide guidance to project proponents on ES\&H, security, facilities issues (engineering, maintenance, and operations) and general operational/logistical issues. The IDT meets weekly to review new activities and significant changes to existing activities. This process also serves as an avenue for project proponents to provide feedback that can be used for both project and ES\&H process improvement. Each functional environment, safety, security, and facility operations program has a representative on the IDT. The environmental program representatives provide project proponents with information and guidance on environmental objectives, compliance, requirements, and other EMS-related topics.

In 2007, SNL/CA began using an electronic data management system to record IDT reviews and compile the results of the review into an electronic report. The electronic report is accessible to the presenter, IDT members, and other designated participants in the process. A paper copy of the report is printed and maintained in the ES\&H Records Center. The IDT record includes an IDT evaluation request, a list of IDT members in attendance, comments and requirements provided by IDT members; and presentation materials. A digital recording of each presentation that serves as meeting minutes is also maintained as a record in the Web File Share database, a corporate database for electronic files.

\subsection{Self-assessments and Audits}

Compliance evaluations are supported by a wide variety of assessments and audits. Implementation of requirements across all SNL/CA operations, as well as management processes, are evaluated through self-assessments and audits. Self-assessment and audit results are maintained as Sandia records either in the ES\&H Records Center or in an online database. Table 13 identifies the types of self-assessments and audits routinely conducted for SNL/CA operations, and the records that result from each.

In 2006, SNL/CA's EMS Program received certification under the international standard for environmental management systems, ISO 14001:2004. The ISO 14001:2004 standard requires annual or semi-annual surveillance audits of certified EMS programs. In 2008, SNL/CA's surveillance audits were conducted in April and September, resulting in continued certification under the ISO standard. 
Table 12 SNL/CA Environmental Assessment and Audit Types

\begin{tabular}{|c|c|c|c|c|c|c|}
\hline Type & $\begin{array}{c}\text { Guidance } \\
\text { Document / } \\
\text { Driver } \\
\end{array}$ & Conducted By & Schedule & Scope & Record Type & Record Maintenance \\
\hline \multicolumn{7}{|c|}{ Line Implementation } \\
\hline $\begin{array}{l}\text { Corporate Line } \\
\text { Self-assessment }\end{array}$ & $\begin{array}{l}\text { ES\&H Manual } \\
\text { Section 22A }\end{array}$ & $\begin{array}{l}\text { All members of } \\
\text { the workforce }\end{array}$ & Monthly & Select ES\&H areas & $\begin{array}{l}\text { Corporate self-assessment } \\
\text { database }\end{array}$ & Online \\
\hline $\begin{array}{l}\text { Division } 8000 \\
\text { Line Self- } \\
\text { assessment }\end{array}$ & $\begin{array}{l}\text { ES\&H Manual } \\
\text { Section 22A }\end{array}$ & Line manager & Annual & Select ES\&H areas & $\begin{array}{l}\text { Division } 8000 \text { ES\&H self- } \\
\text { assessment database }\end{array}$ & Online \\
\hline $\begin{array}{l}\text { Environmental } \\
\text { program line } \\
\text { assessment }\end{array}$ & $\begin{array}{l}\text { Administrative } \\
\text { procedure - } \\
\text { AP800005 } \\
\end{array}$ & $\begin{array}{l}\text { Functional } \\
\text { program lead }\end{array}$ & Annual & $\begin{array}{l}\text { Adequacy and effectiveness of } \\
\text { processes, adequacy of resources, } \\
\text { communication of requirements, line } \\
\text { ownership of requirements }\end{array}$ & Assessment report & $\begin{array}{l}\text { SNL/CA ES\&H } \\
\text { Records Center }\end{array}$ \\
\hline $\begin{array}{l}\text { EP } \\
\text { Representative } \\
\text { assessment }\end{array}$ & $\begin{array}{l}\text { Administrative } \\
\text { procedure - } \\
\text { AP800009 } \\
\end{array}$ & $\begin{array}{l}\text { EP } \\
\text { Representative }\end{array}$ & $\begin{array}{l}\text { Routine / } \\
\text { ongoing }\end{array}$ & $\begin{array}{l}\text { Informal, focus on critical } \\
\text { environmental requirements and trouble } \\
\text { spots }\end{array}$ & Informal report & $\begin{array}{l}\text { SNL/CA ES\&H } \\
\text { Records Center }\end{array}$ \\
\hline \multicolumn{7}{|l|}{ Audits } \\
\hline $\begin{array}{l}\text { External } \\
\text { regulating } \\
\text { agency audits } \\
\text { and inspections }\end{array}$ & $\begin{array}{l}\text { Federal, state, and } \\
\text { local regulations and } \\
\text { permits }\end{array}$ & $\begin{array}{l}\text { Regulatory } \\
\text { Inspectors }\end{array}$ & Annual & $\begin{array}{l}\text { All aspects of facility operations, record } \\
\text { keeping, program processes, and } \\
\text { adherence to permit conditions / } \\
\text { requirements, audits are generally } \\
\text { unplanned and unannounced }\end{array}$ & Official correspondence & $\begin{array}{l}\text { SNL/CA ES\&H } \\
\text { Records Center }\end{array}$ \\
\hline DOE audits & $\begin{array}{l}\text { M\&O Contract, DOE } \\
\text { policies and } \\
\text { requirements }\end{array}$ & DOE auditors & Annual & $\begin{array}{l}\text { Subset of ES\&H programs audited each } \\
\text { year }\end{array}$ & Audit report & $\begin{array}{l}\text { SNL/CA ES\&H } \\
\text { Records Center }\end{array}$ \\
\hline $\begin{array}{l}\text { Management } \\
\text { System audits }\end{array}$ & $\begin{array}{l}\text { M\&O Contract, } \\
\text { Corporate Policy } \\
\text { Statement CPS001.3, } \\
\text { Corporate Policy } \\
\text { Requirement } \\
\text { CPR001.3.5 } \\
\end{array}$ & $\begin{array}{l}\text { Sandia ES\&H, } \\
\text { Quality, and } \\
\text { Safeguards \& } \\
\text { Security } \\
\text { Assessments } \\
\text { Department } \\
\end{array}$ & Annual & $\begin{array}{l}\text { Internal, independent audit of laboratory } \\
\text { systems associated with ES\&H, Quality, } \\
\text { and Safeguards \& Security }\end{array}$ & Audit report & $\begin{array}{l}\text { SNL/CA ES\&H } \\
\text { Records Center }\end{array}$ \\
\hline $\begin{array}{l}\text { Third party } \\
\text { certification }\end{array}$ & ISO 14001 & $\begin{array}{l}\text { External third } \\
\text { party auditor }\end{array}$ & $\begin{array}{l}\text { Recertify } \\
\text { every three } \\
\text { years; } \\
\text { surveillance } \\
\text { semi- } \\
\text { annually }\end{array}$ & $\begin{array}{l}\text { Requirements of the ISO } 14001 \\
\text { Standard }\end{array}$ & Audit report & $\begin{array}{l}\text { SNL/CA ES\&H } \\
\text { Records Center }\end{array}$ \\
\hline
\end{tabular}




\section{EMS Internal Audit and Self-Assessment}

Annually, SNL/CA completes an internal audit of the EMS Program to determine if it conforms to the ISO 14001 Environmental Management System standard, and to ensure that it is properly implemented and maintained. Additionally, the various assessments and audits described in Chapter 14 support management and maintenance of the EMS. SNL/CA maintains an administrative procedure for conducting assessments used in support of the EMS Program (SNL/CA 2008c). Figure 17 summarizes the assessment sources that assist in keeping SNL/CA's EMS on track.

\section{$\underline{\text { SNL/CA EMS Assessments }}$}

\section{Independent Assessments}

\section{- External -}

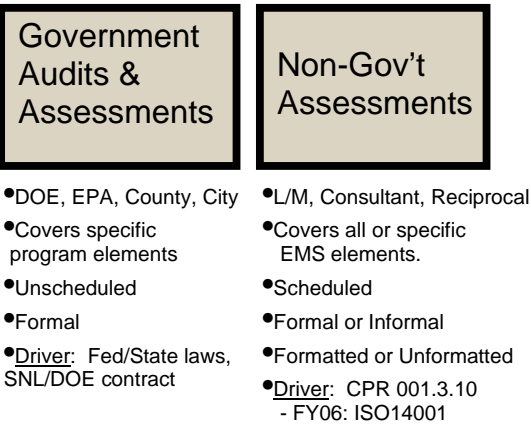

Self Assessments

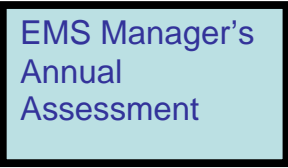

-Review of all EMS elements.

- Scheduled

-Formatted

-Driver: AOP

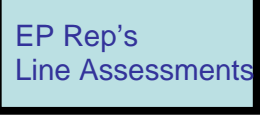

-Assesses targeted env. program requirements -Formatted

-Tracks line trouble spots and trends

- Driver: OP

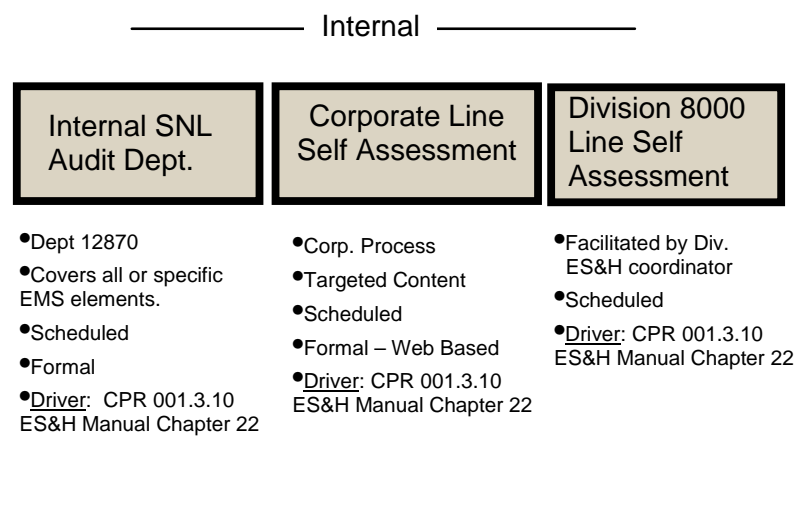

Individual Environmenta Program Assessments (6)

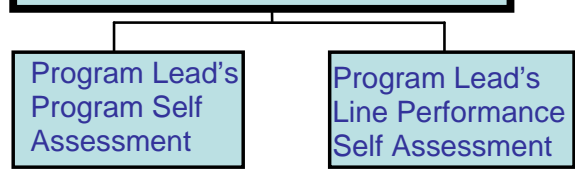

-Looks internally at program mechanics

-Formatted

-Driver: AOP

- Targeted but covers entire breadth of program over a $3 \mathrm{Yr}$ period.

-Formal - planned/designed

-Driver: AOP

Figure 17 Assessments Supporting SNL/CA's EMS Program 


\subsection{Internal EMS Audits}

Sandia's corporate assessment team in the ES\&H, Quality, and Safeguards \& Security Assessments Department (Organization 12870) conducts periodic internal audits of SNL/CA's EMS Program. Internal audits will be completed every three years and will evaluate the EMS Program against the requirements of the ISO 14001 standard. The first internal audit against ISO 14001:2004 requirements was conducted in June 2008. During interim years, the EMS Core Team completes a gap analysis of select ISO elements. The gap analysis provides a broad look at requirements rather than an in-depth comparison against the details of the ISO standard. Internal audit reports and gap analyses are EMS records and maintained in the ES\&H Records Center.

\subsubsection{Audit}

In June 2008, Organization 12870 conducted an audit of the SNL/CA EMS Program against the requirements of the ISO standard. The audit resulted in two issues ${ }^{2}$ requiring corrective action. The first issue relates to discrepancies between information presented in the EMS Manual and similar information maintained on the EMS website. Corrective actions were implemented to update all information presented on the website and to state in Section 1.2 of this manual that information presented on the web is the most up-to-date and that the manual reflects a point-intime. The second issue relates to consideration of small-dollar subcontracts in identifying environmental aspects and undefined operational controls for such activities. Corrective actions were implemented to insert an environmental questionnaire into the contracting process to capture environmental data and identify action-specific controls, when applicable.

\subsubsection{Audit}

The 2009 internal audit of the SNL/CA EMS Program consists of an interim gap analysis against the ISO 14001:2004 standard. The gap analysis was completed in April 2009. No gaps were identified, but several areas of improvement were noted in the areas of communications and awareness and document control.

\subsection{EMS Program Self-Assessments}

The primary self-assessment used for the EMS Program is the annual EMS Management Representative assessment. Other self-assessments may also be used to evaluate the EMS Program, including corporate and DOE assessments. EMS Program self-assessment results are EMS records and maintained in the ES\&H Records Center.

\subsubsection{Assessment}

The EMS Management Representative completed an EMS Program self-assessment in December 2008 with a focus on identifying improvements. The results of the assessment are documented in the Laboratory Enterprise Self Assessment (LESA) database. A self-assessment report is

\footnotetext{
${ }^{2}$ An issue represents a noncompliance with requirements and/or presence of a potentially unacceptable risk.
} 
generated from LESA and submitted to the ES\&H Records Center. The results of the 2008 assessment are summarized below.

- Include the Arroyo Improvement Plan on the Environmental Planning and Ecology Program website.

- Include a date on the "current wildlife issues" website.

- Environmental Planning and Ecology Program should assume a greater role in site development planning to capture and communicate environmental requirements.

- Consider a separate specification for environmental requirements.

- Implement a procedure to routinely remove sediment from LEC pits.

- In the Waste Management Program, review past year assessment results for trends and develop actions to correct negative trends.

- Complete procedures for universal waste items.

- Implement cardboard recycling process.

- Submit Federal Electronics Challenge submission for a site award.

- Develop an energy conservation section on the EMS website that includes corporate targets, conservation tips, and external links.

- Update preferred list of recycled paper products for ease in readability.

- Establish clear baselines for pollution prevention and waste minimization targets.

- Complete the diesel transition plan and communicate to SHEAC.

- Work with corporate Fleet Management Program to adequately reflect SNL/CA in the corporate plan.

- Develop a site vehicle plan.

- Update Fact and Help sheets with current information, place updated sheets on website.

- Work with Badge Office to implement a visitor briefing card.

- Update website with current significant aspects.

- Verify that assessment documents from the CUPA inspection are copied into the 2008 assessment files.

- Complete the installation of sewer flow meters including one at the pump discharge station.

- Devote one core team meeting to review of assessment and corrective action process.

- Review self-assessment reports and assure actionable items are entered into LESA and/or Actions Spreadsheet.

- Convert Quality Assurance Program Plan to a companion to the EMS Manual.

- Develop a list of outreach presentations to line organizations.

- Create metrics for new 2009 targets.

- Input above action items on the Actions Spreadsheet.

\subsubsection{Assessments}

During the fourth quarter of 2009, the EMS Management Representative will complete a selfassessment of the EMS Program. This self-assessment will evaluate each element of the program for improvements in implementation and management. Other than the scheduled gap analysis (see Section 15.1.2), there are no other corporate, division, or DOE assessments planned for the EMS Program in 2009. 


\section{Nonconformity, Corrective, and Preventive Action}

SNL/CA maintains a procedure for identifying nonconformities through a system of audits and assessments. Administrative Procedure AP800005, Environmental Management System Assessment Process (SNL/CA 2008c) describes the various audit/assessment types that are conducted to assess site compliance with environmental regulations and requirements, and continually improve the site EMS. The procedure also describes scheduling, tracking, and management of results. Audits and assessments conducted at SNL/CA are described in Chapters 14 and 15 of this manual.

\subsection{Audit and Assessment Tracking}

SNL/CA environmental and EMS-related audits and assessments are tracked and documented in one of three databases: the LESA database, the Corrective Action Tracking System (CATS), or the EMS Actions Spreadsheet. LESA and CATS are online corporate systems. The EMS Actions Spreadsheet is an Environmental Management Department tool used to capture actions that do not warrant entering into LESA or CATS.

\subsection{Corrective and Preventive Action}

The EMS Core Team and SNL/CA Assurance Department evaluate the results of environmental and EMS-related audits/assessments to identify findings, observations, opportunities for improvement, and noteworthy practices ${ }^{3}$. Corrective actions are established for all findings. SNL/CA uses the corporate Corrective Action Tracking System (CATS) to record and track implementation of environmental and EMS-related corrective actions associated with audit issues / findings from Organization 12870, DOE, or external agencies. Corrective actions from self-assessments (including ISO surveillance audits) are recorded and tracked in LESA or the EMS Actions Spreadsheet. Verification of corrective actions entered into CATS is conducted by an independent verifier, generally a member of SNL/CA's Quality Assurance organization. Verification of corrective actions entered into LESA and the EMS Actions Spreadsheet are verified by the EMS Core Team. A root cause determination is required for all findings entered into CATS.

Preventive actions are established for observations and opportunities for improvement. Preventive actions are recorded in LESA and tracked using an EMS action spreadsheet. Core Team members notify the responsible member of the workforce of the need for preventive actions using the site email system. Verification of preventive actions is conducted by the Core Team.

\footnotetext{
${ }^{3}$ Definitions of terminology are provided in AP800005.
} 


\subsection{Validating Effectiveness of Actions}

SNL/CA's process for validating the effectiveness of corrective and preventive actions for environmental and EMS-related issues is documented in Administrative Procedure AP800010, Validation of Environmental or EMS-Related Corrective / Preventive Actions (SNL/CA 2008b). The EMS Core Team and SNL/CA Assurance Department determine which actions require validation. Actions are selected for validation based on the significance or risk of nonconformity. For example, actions that address serious nonconformities with potential for a fine, significant negative environmental impact, or actions attempting to correct recurring issues, may be selected for effectiveness validation. The validation of an action is documented on an SNL/CA EMS Corrective / Preventive Action Validation Form. Completed forms serve as the ES\&H record of validation. 


\section{Management Review}

Annually, the EMS Management Representative reviews SNL/CA's EMS Program with SHEAC (Section 3.1). Management reviews are intended to ensure continued suitability, adequacy, and effectiveness of the EMS Program. Reviews include the following topics.

- Results of internal audits and evaluations of compliance with legal and other requirements

- Communications from external parties

- Site environmental performance

- Progress in meeting EMS objectives and targets

- Status of corrective and preventive actions

- Follow-up actions from previous management reviews

- Changing circumstances including developments in legal and other requirements related to environmental aspects

- Recommendations for improvements

- Modifications and additions to environmental objectives and targets

In the past year, management reviews were completed in April and October 2008.

During the April management review (conducted April 24, 2008), the EMS presentation included a follow-up on issues from the previous review, results of audits and assessments, compliance and changes to requirements, communications with external parties, the status of corrective and preventive actions, and recommendations for improvements. Actions resulting from this management review are:

- Provide information to center directors and the management team about the hierarchy of environmental risks that can then be communicated to the workforce.

- Evaluate and understand Office of Science expectations related to environmental programs to clearly position SNL/CA for a multi-landlord site.

During the October management review (conducted October 30, 2008), the EMS presentation included a follow-up from the prior review, recent major events, environmental performance for past year, extent to which objectives and targets were met, and new and modified objectives and targets. Actions resulting from this management review are:

- Review status of copper exceedance with site VP.

- Communicate to the workforce about landscape changes underway to conserve water and other resources. 


\section{EMS Documentation}

Documentation to support SNL/CA'S EMS Program is comprised of both EMS-specific and general corporate and site documents and information sources. The SNL/CA EMS Program Manual is the primary EMS document for the site. It describes all elements of the EMS Program, how these elements connect, and it provides reference to other general documents that support the program. The EMS Program Manual documents the process used to identify significant environmental aspects applicable to site operations, and to establish objectives and targets that are measurable and relevant. It serves as a roadmap for continual EMS implementation, assessment, and improvement. The SNL/CA EMS Program Manual is reviewed and updated annually. Other documentation established for the SNL/CA EMS Program includes a communication plan (Appendix D), ES\&H policy/standard of performance (Chapter 2), annual environmental program reports (Appendix B), annual EMS communications calendar (Figure 19), and project management schedules for significant environmental aspects (Chapter 6). EMS documents also include procedures developed specifically for the EMS Program, EMS decision documents, EMS internal audit and self-assessment results, communications with external parties, and results of management reviews. All documents created under the EMS Program are records in accordance with the definition of a record used at Sandia.

Other SNL/CA site-specific and corporate policies, document systems, and databases also support the EMS Program. Figure 18 identifies the documents and document systems that support the SNL/CA EMS Program. 


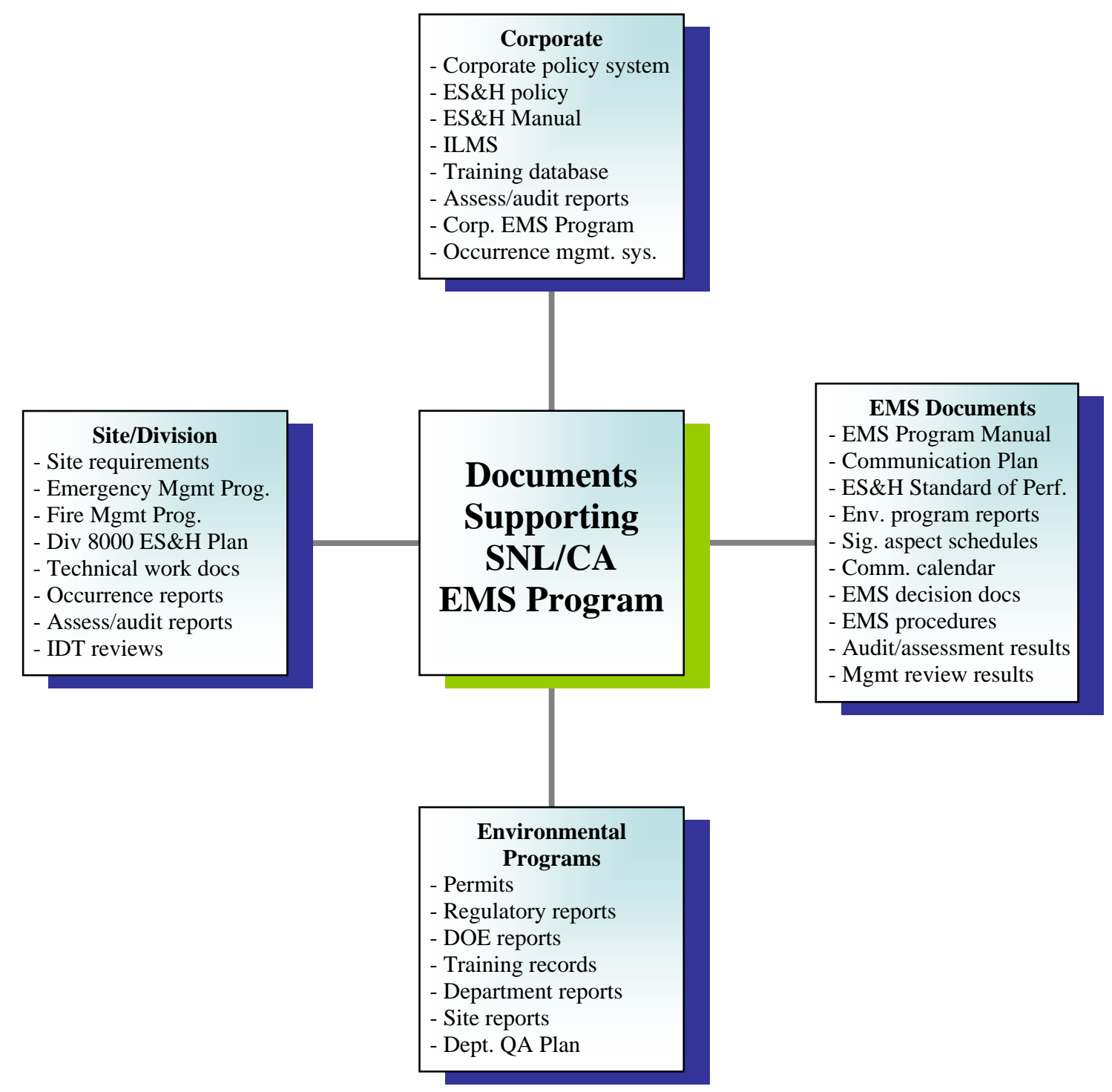

Figure 18 EMS Documentation 


\section{Records}

Sandia manages all information created by Sandia work in accordance with the Corporate Policy System requirements identified in IM 100, Information Management (SNL 2009c). As defined in the information management procedures, information encompasses data, records, published material, and knowledge in written, pictorial, electronic, audio, oral, or other form. To assist the workforce with the requirements for managing information, Sandia developed a Records Management Manual. The Records Management Manual provides guidance on identifying records and non-records, provides a list of federal and DOE requirements governing records management, and summarizes the records retention and disposition schedule. The complete manual is available on the Sandia intranet at http://wwwirn.sandia.gov/recordsmgmt/rmm/Requirements.htm.

SNL/CA maintains an additional procedure for managing ES\&H records, OP471347 Administrative Procedures for Managing Sandia/CA ES\&H Recorded Information (SNL/CA 2008a). This procedure incorporates corporate policies, requirements of the Records Management Manual, best business practices, program-specific regulatory requirements, and the requirements of the ISO 14001 standard. Under this procedure, ES\&H programs are responsible for transmitting recorded information to the SNL/CA ES\&H Record Center for storage and protection. The Record Center establishes file guides for categories of records and assigns a file code number. The file guide describes the record, identifies the retention period, describes the disposition instructions (where applicable), and provides filing instructions. Record Center personnel log all transmitted records into an electronic database. Document titles, dates, authors, and key words are included in the database to assist with tracking and retrieval of records.

SNL/CA established a file guide and code for EMS records in March 2005. The file code is ADMAN-07.05. EMS program documents and supporting information are filed under this code with a permanent retention. SNL/CA maintains separate file guides and codes for other functional environmental program records that also support the EMS Program.

SNL/CA also uses a corporate database, Web File Share, to maintain digital recordings of IDT meetings and other electronic environmental program records. Environmental Program Leads have the option of submitting electronic records to the Web File Share system instead of creating paper copies. Electronic records support reductions in paper use and resources needed to manage and maintain paper records. The Web File Share system has been established and is managed as a permanent record. 


\section{Communications}

SNL maintains an active communication system with established tools and processes to share information both internally and externally. As a result, SNL/CA has many options available to communicate EMS information to the site workforce and to external stakeholders. SNL/CA's Communication Plan Supplement (Appendix D) builds on the corporate EMS communication plan. The supplement identifies the communicators and their roles, outlines the site-specific communication tools used at SNL/CA, and provides a typical list of communication activities.

\subsection{Internal Communications}

The SNL/CA EMS Core Team communicates EMS information to the site workforce through the IDT process, publications, the internal web site, briefings, assessments, and promotional materials. The EMS Core Team receives input on environmental issues, including aspects and impacts, through the IDT process, the NEPA process, an ES\&H telephone hotline, the selfassessment process, and the ES\&H internal web site contacts list. SNL/CA also established an EMS Advisory Committee to facilitate communication between the EMS Core Team and the various organizations on site. The Advisory Committee consists of representatives from various functional areas including administrative support, facilities organizations, research and testing organizations, emergency planning, and procurement. Advisory Committee meetings are held semi-annually to seek input on current issues and concerns related to EMS implementation.

Figure 19 provides a list of actions scheduled and completed in 2009 to promote internal communications.

\subsection{External Communications}

SNL/CA's decision to communicate externally about the EMS program, including significant environmental aspects, is documented in a Memo-To-File (Figure 20). SNL/CA accomplishes external EMS communications through the annual site environmental report and Sandia's external web site at http://public.ca.sandia.gov/casite/about/community/environmental_mgt.php. Figure 20 provides a list of EMS topics included in the annual report. A comment response card is distributed with the annual report and a link is provided on the web site to gather input from external stakeholders. All published information distributed externally must be reviewed and approved for public release in accordance with Sandia requirements.

The EMS Core Team routinely communicates with external parties about elements of the SNL/CA EMS. External communications follow the Administrative Procedure (AP800007), Receiving, Documenting, and Responding to EMS Communications from External Parties (SNL/CA 2008e). Environmental staff members also conduct community outreach efforts by participating in site events, such as family days and site celebrations, and through presentations at local schools and community events. In 2008, Environmental Department staff participated in 
"Bring your sons and daughters to work day" and conducted a presentation on local wildlife at a Livermore elementary school.

Regulating authorities also conduct scheduled and unannounced site audits. These audits provide an additional avenue for communicating with our stakeholders and keeping them abreast of our EMS Program. Finally, SNL corporate is working to include a statement on the external procurement web page to communicate corporate EMS information to current and prospective contractors and suppliers.

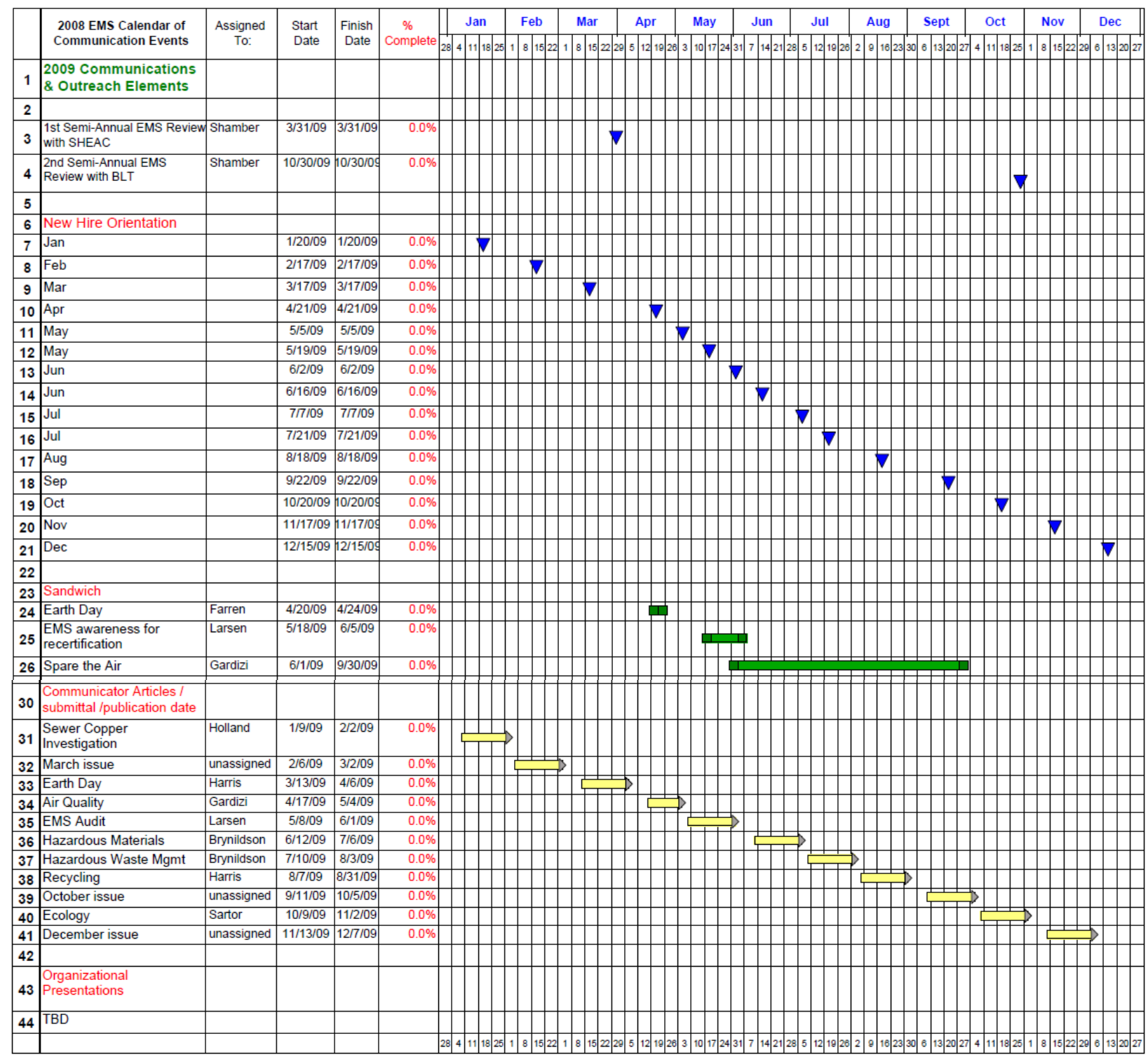

| Figure 19 EMS Communications Calendar, 2009 


\section{Sandia National Laboratories \\ Operated for the U.S. Department of Energy by \\ Sandia Corporation \\ Livermore, California 94551-0969}

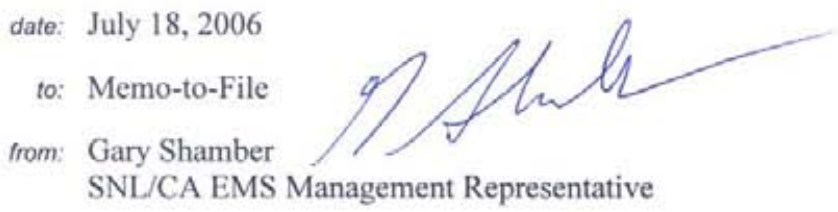

subject: External Communications of the SNL/CA EMS

This Memo-to-File documents SNL/CA's decision to communicate externally on the various elements of its EMS Program. External communications shall be accomplished through an annual environmental report as required by DOE Order 231.1A, Environment, Safety, and Health Reporting. The annual report shall provide information of significant site EMS elements including:

- The site's environmental policy

- Significant environmental aspects and impacts

- Legal and other requirements

- Environmental objectives, targets and programs

- Pollution Prevention and waste minimization

- Resources, roles, responsibilities and authorities

- EMS competence, training and awareness

- Communication and community involvement

- Environmental documentation

- Control of documents

- Operational control

- Emergency preparedness and response

- Monitoring and measurement

- Evaluation of compliance

- Nonconformity and corrective and preventive actions

- Control of records

- Internal audits

- Management Review

SNL/CA's annual report shall include other content items as required by the annual content guidance issued annually by DOE.

The report shall be made available to the external community on Sandia's external website and by direct distribution to interested parties upon request. 


\section{Appendix A - EMS Targets for 2009}

The following targets were approved by SHEAC on October 30, 2008. Targets are grouped under each aspect (green) and objective (blue). All Performance Track targets were removed in March 2009 (plum) because EPA canceled the program.

(Reviewed by EMS Core Team on 8/19/08)

(Reviewed by EMS Advisory Committee on 9/17/08)

(Approved by SHEAC on 10/30/08)

\section{General Environmental Operations}

Objective: Provide exceptional environmental management for the SNL/CA site.

\section{Targets:}

- Receive zero findings per audit per environmental program as the result of annual DOE audits.

- Receive no more than 2 minor non conformances as a result of ISO14001 certification audits.

- Receive no Notices of Violation (NOVs) as a result of any external regulatory agency audit.

- Maintain a level of published environmentally-related communications at 6 per month (total of $72 / \mathrm{FY})$.

- Maintain a level of environmentally-related outreach activities at 4 per month (total of 48/FY).

- By the end of FY2010 achieve a 20\% increase in the EMS awareness survey average score from an FY2008 baseline.

\section{Water Discharges (Significant Aspect)}

Objective 1: Minimize the volume and contamination of sewer water.

\section{Target:}

- Maintain the average weekly composite Zinc and Copper concentrations in sewer below the $50 \%$ regulatory trigger level. (0.5 mg/L for $\mathrm{Cu}$ and $1.5 \mathrm{mg} / \mathrm{L}$ for $\mathrm{Zn}$ )

- Conduct sewer line cleaning and CCTV inspection for all sewer lines 6 inches and greater at least every three years. (Next due in fall 2011) 
- Conduct annual physical survey/visual inspection of all sewer system components (exposed piping, manholes, pump stations, cooling tower basins, sink traps, LEC systems and sumps). (Next due in fall 2009)

Objective 2: Minimize the volume and pollution of storm water runoff.

\section{Targets:}

- $100 \%$ of new construction will have post-construction runoff equal to or less than preconstruction runoff.

- $100 \%$ inspection / cleaning of on site storm drain system including drop structures by October 1 of each year.

- By Sept 1 of each year implement runoff controls for $100 \%$ of bulk erodable landscape and construction material.

\section{Air Emissions (Significant Aspect).}

Objective: Minimize air emissions related to operations and transportation with particular emphasis on Spare-the-Air days.

\section{Targets:}

- Maintain on site fueling operations on Spare-the-Air-Days at (an average of) less than or equal to 3 fill ups/STAD.

General Transportation (Significant Aspect)............................

Objective: Maximize the use of commute alternatives by members of the workforce.

\section{Target:}

- In FY15 increase the use of single driver commute alternatives by 25\% from the FY06 commuter survey established baseline. Alternatives include: carpooling, mass transportation, purchase/use of hybrids, biking/walking, telecommuting.

Objective: Minimize the environmental impacts of transportation.

- SLN/CA commits to reduce the use of transportation fuels (diesel, gasoline, and E85) by 10\% by 2010 from a baseline year of 2006 (from 32,548 to 29,293 gallons). PERFORMANCE TRACK TARGET . Target removed because EPA canceled the Performance Track Program in March 2009. 


\section{Land Use (Significant Aspect)}

Objective 1: Enhance the natural habitat.

\section{Targets:}

- Complete the most critical actions identified in the Arroyo Seco Management Plan within 10 years of receipt of the 10 year permit (Permit received Sept 25, 2008).

- SNL/CA commits to complete four of the Arroyo Seco Improvement projects by 2010. PERFORMANCE TRACK TARGET Target removed because EPA canceled the Performance Track Program in March 2009.

Objective 2: Design and manage all buildings and facilities using "green” principles.

\section{Material Procurement and Use}

Objective: Procure and use environmentally friendly products and materials.

\section{Targets:}

- In FY10 purchases made by Affirmative Procurement Program will equal or exceed 96\% of available procurements.

- In FY09 100\% of purchased general use computers will meet or exceed EPEAT silver requirements.

- SNL/CA commits to increase the recycled content of paper products purchased by $10 \%$ by 2010 from a baseline year of 2006 (from 38,884 to 42,772 lbs). PERFORMANCE TRACK TARGET Target removed because EPA canceled the Performance Track Program in March 2009.

- In FY10 increase the use of bio based products by 25\% from the FY08 amounts.

\section{Hazardous Material.}

Objective: Minimize the use of hazardous material.

\section{Targets:}

- Maintain an annual overall Chemical Information System reconciliation of $>94 \%$.

- Maintain an annual Chemical Information System reconciliation of $100 \%$ for the NFPA 704 health hazard rated 4 materials greater than $10 \%$ of laboratory scale quantities (4 lbs solid, 0.5 gal liquid, $1 \mathrm{lb}$ gas). 


\section{Solid Waste}

Objective: Minimize the quantity of landfill waste through reduced consumption and/or reuse/recycling.

\section{Targets:}

- In FY10 decrease the amount of copy paper purchased by 5\% from the FY05/06 average.

- Maintain $100 \%$ recycling of recyclable quality wood, concrete/asphalt and green landscape waste.

\section{Water Use}

Objective: Minimize site water consumption.

\section{Target:}

- In FY15 achieve a reduction in site water consumption by $16 \%$ from a FY07 baseline. (from 69,901 kgal to 58,717 kgal) (EO 13423)

- SNL/CA commits to reduce the quantity of water used on site by $6 \%$ by 2010 from a 2006 baseline (from 69,908,244 gallons to 65,713,749 gallons). PERFORMANCE TRACK TARGET. Target removed because EPA canceled the Performance Track Program in March 2009.

- No landscape watering between 7am and 7pm except for testing and maintenance.

\section{Objectives with no Current Established Targets}

\section{Hazardous Waste (Significant Aspect)}

Objective: Minimize the generation of hazardous waste.

Universal Waste

Objective: Maintain effective and efficient processes for the management of Universal Waste.

\section{Use of Biological Agents}

Objective: Minimize the use of biological materials.

\section{Radiological Material}

Objective: Minimize the use of radiological materials.

\section{Radiological \& Mixed Waste}

Objective: Minimize the generation of radiological and mixed waste.

\section{Contaminated Areas}

Objective: Minimize the environmental impacts of site contaminated areas. 


\section{Legacy Asbestos}

Objective: Reduce site legacy asbestos material.

\section{Hazardous Material Transportation}

Objective: Minimize the potential environmental effects of hazardous material due to transportation.

\section{Earthquake}

Objective: Minimize the environmental effects of a site seismic event.

\section{Fire}

Objective: Minimize the environmental effects of a site fire emergency.

Natural Gas Use.

Objective: Minimize site natural gas consumption.

Defer to corporate program.

Electrical Use.

Objective: Minimize site electrical consumption.

Defer to corporate program. 


\title{
Appendix B - Environmental Program Reports
}

Annual environmental program reports are available on the SNL/CA ES\&H website. Listed are the links to each report. The official record of this manual stored in the ES\&H Records Center contains a hard copy of each report.

\author{
Air Quality Program \\ http://surf.ran.sandia.gov/centers/8500/snl_ca_air_quaility_program_annual_report
}

\section{Environmental Monitoring Program}

http://surf.ran.sandia.gov/centers/8500/snl_ca_environmental_monitoring_program_annual_repo rt

\section{Environmental Planning and Ecology Program}

http://surf.ran.sandia.gov/centers/8500/esh/CA-EnvMgmt/programs/PE

\section{Hazardous Materials Management Program}

http://surf.ran.sandia.gov/centers/8500/snl_ca_hazardous_material_management_program_annua l_report

Pollution Prevention and Waste Minimization Program

http://surf.ran.sandia.gov/centers/8500/esh/CA-EnvMgmt/programs/PP/reports

\section{Waste Management Program}

http://surf.ran.sandia.gov/centers/8500/snl_ca_waste_management_program_annual_report 


\section{Appendix C - ES\&H Quality Assurance}




\title{
Quality Assurance of Data, Documents and Select Activities of the Environmental, Safety and Health Departments, 8516 and 8517
}

\author{
Sandia National Laboratories, California
}

\section{Approved:}

$\overline{\text { Ed Cull, } 8510 \quad \text { Date }}$




\subsection{ORGANIZATION}

Environmental Operations Department (8516) at Sandia National Laboratories, California manages the following site environmental programs:

- Air Quality

- Environmental Planning

- Environmental Monitoring and Restoration

- Waste Management

- Pollution Prevention / Waste Minimization

- Hazardous Materials Management

- Chemical Inventory System

Health and Safety Department (8517) manages the following worker health and safety programs:

- Industrial Hygiene

- Safety Engineering

- Radiation Protection

- Self Assessments

- ES\&H Coordination

- Occurrence Reporting

- Injury/Illness Reporting

\subsection{SCOPE}

This document defines general procedures, actions and activities implemented to ensure that all ES\&H data and documents produced by these departments are managed and maintained in a manner that ensures their accuracy, consistency, validity and retrievability. It applies, but is not limited to the following:

- all data collected, used or generated

- technical work documents

- technical reports and official correspondence

- SNL/CA ES\&H web pages and associated/included links

- directory and reference information

- Internal and External Audit Corrective Action Plans

This document also addresses certain procedures, actions and activities implemented to ensure the high quality of two department processes including:

- training

- annual program assessments for program effectiveness 
Each ES\&H program will determine the need to produce a program-specific quality assurance plan. If required, these plans are expected to vary based on the requirements of the individual programs, but should contain, at a minimum, the 10 QA criteria listed in DOE Order 414.1B and 10 CFR 830.122.

This document tiers from the SNL/CA Quality Assurance Program Plan found at https://wfsprod01.sandia.gov/groups/sm-uscitizens/documents/document/wfs070514.pdf

\subsection{DATA - Collected, Used or Generated}

Data collected, used or generated by the staff within ES\&H must be representative, complete, comparable, accurate, and precise as follows:

- Representative. Determine data collection or sampling methods. Establish rationale for sampling scheme. Samples collected will be handled in accordance with OP471310 Administrative Procedure for Control of Samples by the Environmental Operations Department. All data must be accompanied with appropriate and consistent units of measure.

- Complete. Determine the acceptable quantity of data actually collected compared to the quantity of data planned to be collected.

- Comparable. When possible, sample collection strategies and methods will be based on published guidelines or standards, such as Occupational Safety and Health Standards, Federal Standards, or national consensus standards such as ASTM, ANSI, or other industry standard.

- Accurate. Determine appropriate methods to assure the accuracy of the data.

- Precise. Determine appropriate methods to assure the precision of the data.

All chemical analytical data must meet the requirements of OP471613 Verification of Laboratory Chemical Analysis Data.

\subsection{Data Management}

Hardcopies of data will be maintained in accordance with OP471347 Administrative Procedures for Managing Sandia/CA ES\&H Recorded Information.

Where feasible and desirable data may be maintained electronically. This may take many forms, and is left to the discretion of the Program Leads. At a minimum, the data maintained electronically will be verified to be complete and accurate on an annual basis. Electronic data will either be stored on a corporate server (to ensure daily back-ups), or backed-up monthly using removable media (i.e. CDs or DVDs).

\subsection{Data Analysis}

Any required statistical analyses of data will be carried out in accordance with either: 1) guidance on statistical analyses provided by a regulatory agency, or 
2) guidance pertinent to the type of data, quantity of data, and end use of the analysis. This guidance may be found in textbooks, statistics software or obtained from specialized training.

\subsection{TECHNICAL WORK DOCUMENTS}

Technical Work Documents (TWD) are formally approved work documents used to identify activity-specific hazards and their associated work control measures. TWDs may include the following:

- standard operating procedures (SOPs)

- health and safety plans (HASPs)

- operating procedures (OPs)

- permits, such as safe work permits (SWPs) and radiological work permits (RWPs)

- data packages for pressure and vacuum systems

- safety and health programs for hazardous waste operations (HAZWOPER)

- plans, such as emergency response plans and facility- or building-specific evacuation/emergency plans.

TWDs will be produced in accordance with ES\&H Manual Chapter 21 Technical Work Documents (TWDs).

TWDs must be reviewed and approved before the work activities are performed. If a TWD expires before a planned revision or scheduled update is completed, the responsible Department Manager will issue a memorandum to file extending the previous revision expiration date. The extension shall be for a period of no longer than 60 days.

Substantive changes require an Interim Change Notice to be submitted and approved as described in EP401502 Procedure for Control of Environment, Safety, and Health (ES\&H) Documents.

For minor changes to TWDs, it is acceptable to line through text and write in new text on the working copy, sign and date the changes. These changes should also be reflected on electronic versions of the TWD. The original shall be updated during the next revision cycle to reflect all minor changes recorded on the working copy.

Each ES\&H program lead will conduct an annual review of TWDs supporting their respective program as part of the program annual self assessment. The review will be documented using the Programmatic Document Review Form. (Attachment A). The review shall consider the TWDs as a "system" of documents and assure that each is appropriately cross referenced and use consistent content. Upon completion, the form shall be submitted to the ES\&H Records Center and incorporated as part of the annual program self assessment documentation.

\subsection{Operating Procedures}


Operating Procedures will be developed in accordance with GN470098 Developing ES\&H Procedures. Operating Procedures are assigned a review period by the author between one to three years. An email notification is sent to the author 60 days and 30 days before the procedure is due to expire. It is recommended that each program keep an updated list of procedures and their expiration dates in order to assure that the document does not become expired.

\subsection{Primary Hazard Screens and Hazard Analyses}

Primary Hazard Screens (PHSs) and Hazard Analyses (HAs) are required to be produced before any new activity or operation that represents significant risks. PHSs and HAs must be reviewed on an annual basis. Notification of impending expiration is given to the author by the ES\&H Coordinators. In addition the corporate data base issues a notice 30 days in advance of the expiration.

\subsection{TECHNICAL REPORTS, DOCUMENTS and OFFICIAL CORRESPONDENCE}

All SAND reports will be produced in accordance with the current guidance for producing SAND documents. Guidance for producing SAND reports is available as SAND 2002-2068P.

Other program documents include plans, reports, permit applications, or other documents required by DOE or other regulatory agencies. These will be reviewed and updated as required by the pertinent regulation or other published guidance.

\subsection{Style Guide}

The ES\&H Departments will follow the Center 6300 Writer's Guide for all documents produced with the exception of SAND reports. The Center 6300 Writer's Guide can be found at: http://www-irn.sandia.gov/corpdata/eshmanuals/eshmc/WriterGuide/writerguide.htm.

\subsection{Approved ES\&H Acronyms and Definitions}

Acronyms commonly used by the ES\&H Departments will be consistently applied in all documents. The approved list of acronyms is included as Attachment B. Word definitions will be consistent with the ES\&H Manual Glossary.

\subsection{Approved ES\&H Job Positions/Titles}

Approved job positions/titles within the ES\&H Departments are included as Attachment C. These titles should be used consistently throughout all department TWDs, technical reports and official correspondence. 


\subsection{SNL/CA ES\&H WEB PAGES AND LINKS}

Web pages will be designed in accordance with the How to Write Web Pages for SNL's

Webs, which can be found at:

http://www-im.sandia.gov/webmentor/write-pages/index.htm.

Each Department Manager and Program Lead will review for completeness and accuracy the web pages and the included or associated links that support the department or respective programs. This will be completed during the annual program self assessments. The review shall include, but not necessarily be limited to:

- Review content for concurrence with the referenced program requirements and activities.

- Review contact information to ensure that current program personnel are listed.

- Test all links on web pages.

The review of these will be documented using the Programmatic Document Review Form (Attachment A).

\subsection{DIRECTORY AND REFERENCE INFORMATION}

All department directories and staff reference information will be reviewed no less than quarterly by the department office management assistant for accuracy and completeness.

\subsection{JOB QUALIFICATIONS AND TRAINING}

Each position within the ES\&H Departments provides unique support to the EMS and ISMS. It is important that each staff member of the department be qualified and well trained to perform the duties of the position.

\subsection{Job Qualifications}

The required job qualifications of each staff position are determined by the department manager. These qualifications are based on a combination of academic credentials, prior applicable experience, specialized credentials, and subjective attributes determined to be necessary for the position. The department manager will follow the corporate guidance for filling vacancies or new positions within the department. The department manager will exercise the right to move existing staff to new positions within the department as necessary for improved operations and/or staff development or growth. 


\subsection{Job Training}

There are three types of training applicable to members of the workforce within the ES\&H Departments. These are:

- General corporate required training.

- Specific training required to perform the assigned job function (as determined by the department manager and/or program lead).

- Specific training required by regulations (as determined by the program lead).

It is the responsibility of the department manager, in consultation with the program leads (where appropriate) to identify the required training for each member of the workforce within the ES\&H departments. Required training shall be identified for each position listed in Attachment C "Approved ES\&H Job Positions/Titles."

It is the responsibility of each member of the workforce to ensure that their training requirements are met and remain current.

\subsection{Lapses in Training}

For training that includes a requirement for periodic re-training or recertification, a lapse is considered to have occurred after a member of the workforce does not meet the deadline for re-training or re-certification.

When such a lapse occurs, the staff member will discontinue all activities governed or associated with the training until such time the re-training or recertification is completed, unless a temporary authorization is approved by the Department manager

\subsection{ENVIRONMENTAL PROGRAM'S ASSESSMENT}

Annually, each program within the ES\&H Departments will conduct assessments to determine the program's efficiency and effectiveness. Assessments need not cover the entire breadth of the program in a given year; they may be focused on a specific subset of elements of the program. It is anticipated, however, that all program elements will be assessed at least once in a three year period.

The ES\&H Departments will follow the Self Assessment Program Operating Procedure OP471726.

For the Environmental Operations Department the following two program assessments are to be performed annually for each environmental program:

\subsection{Program Self Assessment}

The Program Self Assessment is an annual effort to determine the completeness, quality and efficiency of the program structure and 
management. It shall also be used to determine the alignment of the program with ISO14001 EMS requirements and principles.

The objective of this assessment is to assure that the program provides all of the required elements and continually strives for areas of improvement. This assessment will include a review of all procedures, processes, technical work documents, web pages, publications, communications, etc. of the program to assure that they are streamlined, accurate and current. The Programmatic Document Review Form should be used to document this part of the self assessment. (Attachment A).

\subsection{Program Line Implementation Assessment}

The Program Line Implementation Assessment is an annual effort to determine how well the line or site is implementing the provisions or requirements of the program or supporting specific program-related objectives/targets. The success or failure of the line or site to implement program requirements or provisions can be attributed to many things: culture, line management support, communications, program management, etc. (Note: Poor program implementation by the line may not necessarily indicate poor program management or execution, but the Program Lead should consider whether these are contributing factors and take appropriate action.)

Significant line violations to program requirements that are discovered during this assessment shall be input into the ES\&H Self Assessment database for communications and tracking. (Note: the assessment should be "big picture" and not just conducted to find violations.) See Attachment D for the Assessment Finding Form. The completed form is submitted to the Division 8000 ES\&H coordinator for entry into the self-assessment tracking system.

In conducting these assessments the Program Lead shall consider aligning with the scheduled Line Self Assessments conducted by the ES\&H Coordinators. This will minimize the disruption to the line and gain the manager's attention.

For Dept 8516 each assessment and its results shall be summarized in the annual update of each environmental program's Program Plan. It shall include:

- A discussion of the scope of the assessment and the rationale,

- The methods used to conduct the assessment,

- A clear summary of the results,

- A discussion of the findings, strengths/weaknesses, recommendations, and areas for improvement.

- A summary of actions taken.

For Dept 8516 two additional department assessment activities will be conducted within the department to determine the implementation of environmental program requirements by the line. The results of each of these shall be provided to the Program Leads to be used as additional input to either of the above two required program assessments: 
April 28, 2005

\subsection{Environmental Programs Representative Assessment}

The Environmental Programs Representative will perform and record informal assessments of line implementation of critical program elements as negotiated with each program lead. These are not formally scheduled but are conducted on an on-going basis as part of the EP Reps scope of duties. See OP472165.

\subsection{IDT Requirements Follow-Up Assessment}

IDT reviews may generate environmental program requirements that the line presenter must address as part of the execution of his project. The IDT Requirements Follow-Up Assessment is a random "spot check" on a percentage of projects presented at IDT to determine if the requirements that were given as a result of IDT were implemented by the line. The Environmental Program Representative / IDT Coordinator will perform this follow-up assessment. The results of these follow-up assessments may be useful input into the program self assessments. See OP471680.

All four assessments described above shall be documented and retained in accordance with OP471347 Administrative Procedures for Managing Sandia/CA ES\&H Recorded Information. 


\section{Attachment A PROGRAMMATIC DOCUMENT REVIEW FORM}




\section{PROGRAMMATIC DOCUMENT REVIEW FORM}

\begin{tabular}{|c|c|c|c|}
\hline Document Type & Document Title & $\begin{array}{l}\text { Review } \\
\text { Complete / Date }\end{array}$ & Changes Made \\
\hline \multirow[t]{3}{*}{ Operating Procedure } & $\begin{array}{l}\text { Sanitary Sewer Outfall } \\
\text { Monitoring (OP471410) }\end{array}$ & $\square$ & $\begin{array}{l}\square \text { Yes } \\
\square \text { No }\end{array}$ \\
\hline & Incident Reporting (OP471608) & $\square$ & \\
\hline & $\begin{array}{l}\text { Categorical Process Monitoring } \\
\text { (OP471409) }\end{array}$ & 0 & $\begin{array}{l}\square \text { Yes } \\
\square \text { No }\end{array}$ \\
\hline PHS & $\begin{array}{l}\text { SNL8A00186-009 } \\
\text { Environmental Monigin in }\end{array}$ & & $\begin{array}{l}\square \text { Yes } \\
\square \text { No }\end{array}$ \\
\hline \multirow[t]{3}{*}{ Other Program Documents } & & $\square$ & \begin{tabular}{|l}
$\square$ Yes \\
$\square$ No
\end{tabular} \\
\hline & $\begin{array}{l}\text { tontutellution } \\
\text { Devention Plan for } \\
\text { Construction Activities }\end{array}$ & $\square$ & $\begin{array}{l}\square \text { Yes } \\
\square \text { No }\end{array}$ \\
\hline & $\begin{array}{l}\text { Stormwater Pollution } \\
\text { Prevention Plan (Industrial + } \\
\text { MS4) }\end{array}$ & $\square$ & $\begin{array}{l}\square \text { Yes } \\
\square \text { No }\end{array}$ \\
\hline \multirow[t]{4}{*}{ Web Pages } & Program General Web Page & $\square$ & $\begin{array}{l}\square \text { Yes } \\
\square \text { No } \\
\end{array}$ \\
\hline & Stormwater Web Page & $\square$ & $\begin{array}{l}\square \text { Yes } \\
\square \text { No }\end{array}$ \\
\hline & Sanitary Sewer Web Page & $\square$ & $\begin{array}{l}\square \text { Yes } \\
\square \text { No }\end{array}$ \\
\hline & SPCC Training Page & $\square$ & $\begin{array}{l}\square \text { Yes } \\
\square \text { No }\end{array}$ \\
\hline
\end{tabular}

\section{Organization:}

Program:

Date:

Signature:

Program Lead

Directions:

- Use this form to track review of all programmatic TWDs.

- Fill in the type and title of your program documents

- After completion, file form with your program records. 
EMS Program Manual

April 2009

Quality Assurance - ES\&H Data, Documents and Activities

12 of 23

April 28, 2005

Attachment B

APPROVED ACRONYMS

93 of 111 


\section{Acronyms}

AAQS - Ambient Air Quality Standards

ABIH - American Board of Industrial Hygiene

ACGIH - American Conference of Government Industrial Hygienists

ADA - Americans with Disabilities Act

ALARA - As Low As Reasonably Achievable

ANSI - American National Standards Institute

ASER - Annual Site Environmental Report

ASLL - facility code assigned to SNL/CA by Nevada Test Site

ATC - Authority to Construct

ASTM - American Society for Testing and Materials

AWCO - Alternate Waste Certification Official

BA - Biological Assessment

BAAQMD - Bay Area Air Quality Management District

BCSC - Biological Chemistry Safety Committee

BiOp - Biological Opinion

BMBL - Biosafety in Microbiological and Biomedical Labs

BSL - Biosafety Level, e.g. BSL-1 is biosafety level 1, etc.

BTEX - Benzene, Toluene, Ethylbenzene, and Xylene

CAA - Clean Air Act

CAAA - Clean Air Act Amendments

CARB - California Air Resources Board

CCR - California Code of Regulations

$\mathrm{CDC}$ - Centers for Disease Control

CDFG - California Department of Fish and Game

CERCLA -Comprehensive Environmental Response, Compensation, and Liability Act

CESA - California Endangered Species Act

CFC - Chlorofluorocarbons

CFR - Code of Federal Regulations

$\mathrm{CIH}-$ Certified Industrial Hygienist

COC - Chain-of-Custody

CRD - Confidential Restricted Data

CRLF - California Red-Legged Frog

CRMP - Cultural Resources Management Plan

CTS - California Tiger Salamander

DOD - US Department of Defense

DOE - US Department of Energy

DOT - US Department of Transportation

DQO - Data Quality Objective

DR - Disposal Request

DTSC - Department of Toxic Substances Control

EA - Environmental Assessment

EIS - Environmental Impact Statement

EIR - Environmental Impact Report 
EMS - Environmental Management System

$\mathrm{EO}$ - Executive Order

EPA - US Environmental Protection Agency

EPP - Environmentally Preferable Purchasing

ERG - Emergency Response Guide

ES\&H - Environment, Safety, and Health

ESA - Endangered Species Act

FIFRA - Federal Insecticide, Fungicide, and Rodenticide Act

FONSI - Finding of No Significant Impact

GPMPP - Groundwater Protection Management Program Plan

GSA - General Services Administration

HA - Hazards Analysis

HAP - Hazardous Air Pollutants

$\mathrm{HBV}$ - hepatitis B virus

HCP - Hearing Conservation Program

HEPA - High Efficiency Particulate Air

HIV - Human Immunodeficiency Virus

HWT - Hazardous Waste technician

HWTSF - Hazardous Waste Treatment and Storage Facility

IAQ - Indoor Air Quality

IARC - International Agency for Research on Cancer

IBC - Institutional Biosafety Committee

IBDC - Inhabited Building Distance Calculations

IDLH - Immediately Dangerous to Life and Health

IDT - Interdisciplinary Team

$\mathrm{IH}$ - Industrial Hygiene

IHSR - Industrial Hygiene Services Report

IS - Initial Study

ISMS - Integrated Safety Management System

LC - Lethal Concentration

LD - Lethal Dose

LDR - Land Disposal Restriction

LECS - Liquid Effluent Control System

LEL - Lower Explosives Limit

LFL - Lower Flammability Limit

LLNL - Lawrence Livermore National Laboratory

LOD - Limit of Detection

LOQ - Limit of Quantitation

LWIS - Low-Level Waste Information System

MAWP - Maximum Allowable Working Pressure

MBTA - Migratory Bird Treaty Act

MC\&A - Material Control and Accountability

MCLs - Maximum Contaminant Levels

MLLW - Mixed Low-Level Waste

MSD - Musculoskeletal Disease

Mt-Metric Ton 
NAAQS - National Ambient Air Quality Standards

ND - non detectable

NDDB - California Natural Diversity Database

NegDec - Negative declaration

NEPA - National Environmental Policy Act

NESHAP - National Emission Standard for hazardous Air Pollutants

NEW - Net Explosive Weight

NFA - No Further Action

NFPA - National Fire Protection Association

$\mathrm{NIH}$ - National Institutes of Health

NIOSH - National Institute of Occupational Safety and Health

NNSA - National Nuclear Security Administration

NPDES - National Pollutant Discharge Elimination System

NQA - Nuclear Quality Assurance

NSO - Nevada Site Office

NTP - National Toxicology Program

NTS - Nevada Test Site

ODC - Ozone Depleting Substances

OEA - Occupational Exposure Assessment

OP - Operating Procedure

OSHA - Occupational Safety and Health Administration

P2 - Pollution Prevention

PAPR - Power Air Purifying Respirator

PCB - Polychlorinated biphenyl

PEL - Permissible Exposure Limit

PK - Process Knowledge

PKE - Process Knowledge Evaluation

$\mathrm{PM}_{10}$ - respirable particulate matter

POTW - Publicly Owned Treatment Works

PPE - Personal Protective Equipment

PPOA - Pollution Prevention Opportunity Assessment

PQL - Practical Quantification Limit

PSDR - Package Storage and Disposal Request

PSIG - Pound per square inch, gauge

PTO - Permit to Operate

QA - Quality Assurance

QAP - Quality Assurance Plan

QAPP - Quality Assurance Program Plan

QC - Quality Control

QDC - Quantity Distance Calculation

RCA - Root Cause Analysis

RCRA - Resource Conservation and Recovery Act

RCT - Radiological Control Technician

RDL - Reportable Detection Limit

$\mathrm{RG}$ - Risk Group, e.g. RG1 is risk group 1, etc.

RMI - Repetitive Motion Injury 
RMWSF - Radioactive and Mixed Waste Storage Facility

RP - Radiation Protection

RSI - Repetitive Strain Injury

RWAP - Radioactive Waste Acceptance Program

RWP - Radiological Work Permit

RWQCB - Regional Water Quality Control Board

RWR - Radioactive Waste representative

SAW - Sampling and Analysis Worksheet

SB-14 - Source reduction Evaluation Review and Plan; Hazardous Waste Management Performance Report; Summary Progress Report; State of California Senate Bill 14

SE - Safety Engineering

SIP - State Implementation Plan

SLB - Shallow Land Burial

SME - Subject Matter Expert

SOP - Standard Operating Procedure

SSO - Sandia Site Office

STLC - Soluble Threshold Leaching Procedure

SWEA - Final Site-Wide Environmental Assessment

SWP - Safe Work Permit

SWPP - Stormwater Pollution Prevention Plan

TAC - Toxic Air Contaminants

TCLP - Toxicity Characteristic Leaching Procedure

TI - Transport Index

TID - Tamper Indicating Device

TLD - Thermoluminescent Dosimeter

TLV - Threshold Limit Value

TPHD - Total Petroleum Hydrocarbons, diesel

TRI - Toxic Release Inventory

TRU - Transuranic

TSCA - Toxic Substances Control Act

TSD; TSDF - Treatment, Storage, and Disposal Facility

TTLC - Total Threshold Limitation Concentration

TTO - Total Toxic Organics

TWD - Technical Work Document

UEL - Upper Explosive Limit

UFL - Upper Flammability Limit

UN - United Nations

USFWS - US Fish and Wildlife Service

UST - Underground Storage Tank

VOC - Volatile Organic Compound

WAC - Waste Acceptance Criteria

WCO - Waste Certification Official

WCPP - Waste Certification Program Plan

WDDR - Waste Description and Disposal Request

WDT - Radioactive Waste and Mixed Waste Disposal Tag 
EMS Program Manual

April 2009

Quality Assurance - ES\&H Data, Documents and Activities

17 of 23

April 28, 2005

WET - Waste Extraction Test

WIMS - Waste Information Management System

WMS - Waste Management System

WMS- California Waste Management System

WPE - Waste Program Engineer

WSE - Workstation Evaluation 


\section{Job Positions/Titles \\ Environmental Operations}

\section{General}

- Environmental Operations Department Manager

- Environmental Operations Technician

- Assessment Team Leader

- ES\&H Coordinator

- Field Chemist

- Quality Assurance Coordinator

- Purchaser

- Sampler

- Traffic Manager

Air Quality Program

- Air Quality Program Lead

- Air Quality Contractor Support

Environmental Monitoring Program

- Environmental Monitoring Program Lead

- Associate Engineer, Environmental Monitoring Program

- Senior Engineer, Environmental Monitoring Program

Environmental Planning Program

- Environmental Planning Program Lead

- Environmental Planning Program Technologist

- Wildlife Biologist

- Wildlife Biology Intern

- Wildlife Technologist

Hazardous Material Program

- Hazardous Materials Management Program Lead

- Hazardous Materials Technician

Waste Management Program

- Waste Management Program Lead

- Waste Management Program Engineer

- Waste Certification Official

- Waste Management Training Coordinator

- Waste Stream Evaluator

- Hazardous Waste Technician

- Nonconforming Reporting Coordinator

- Nuclear Materials Representative

- Radiation Protection Staff Program Lead

- Radiation Protection Staff Technologist 
- Radioactive Waste Representative

- Radiological Control Technician

Pollution Prevention / Waste Minimization Program

- Pollution Prevention / Waste Minimization Program Lead

- Pollution Prevention / Waste Minimization Technician

\section{Health and Safety}

Industrial Hygiene

- Industrial Hygienist

- Industrial Hygiene Technologist

- Bio safety Officer

- Ergonomics Technologist

Safety Engineering

- Safety Engineer

- Safety Engineering Technologist

- Construction Safety Inspector

- Injury/Illness Reporting Clerk

$\underline{\text { Radiation Protection }}$

- Health Physicist (Radiological Engineer)

- Radiological Control Technician

- Division Laser Safety Officer

\section{ES\&H Coordinator}

- Division ES\&H Coordinator

- Center ES\&H Coordinator

- Self Assessment Program Lead

- Self Assessment Program Coordinator 


\section{Attachment D ENVIRONMENTAL OPERATIONS ASSESSMENT FINDING FORM}


Quality Assurance - Environmental Data and Documents 9/27/05

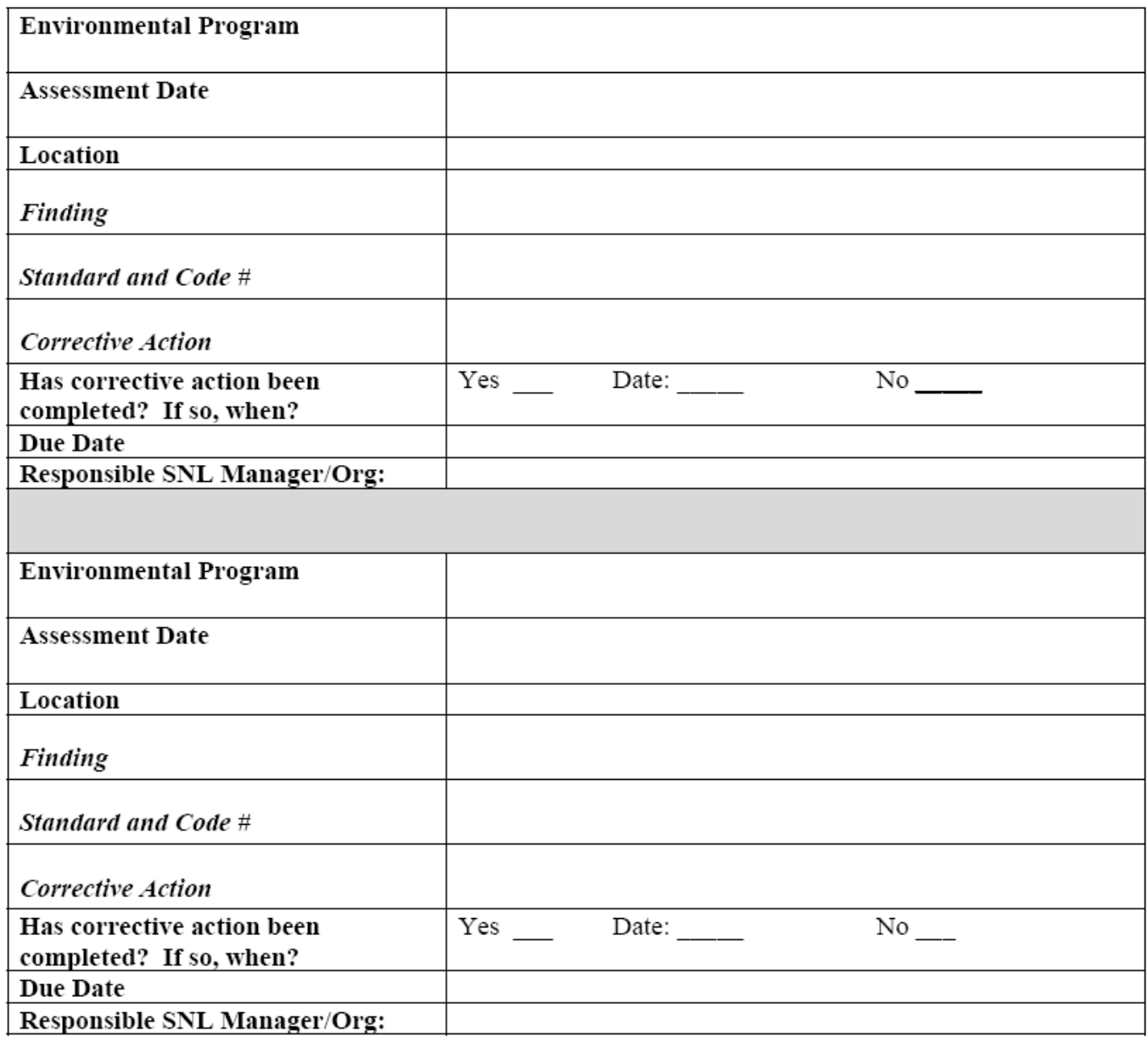

Note: In August 2006, this form was modified. The new form was distributed for use to the EMS Core Team on August 16, 2006. 
By my signature below, I affirm that I have read and understood this OP and all references called out

in procedural steps, and I agree to operate within the stated constraints.

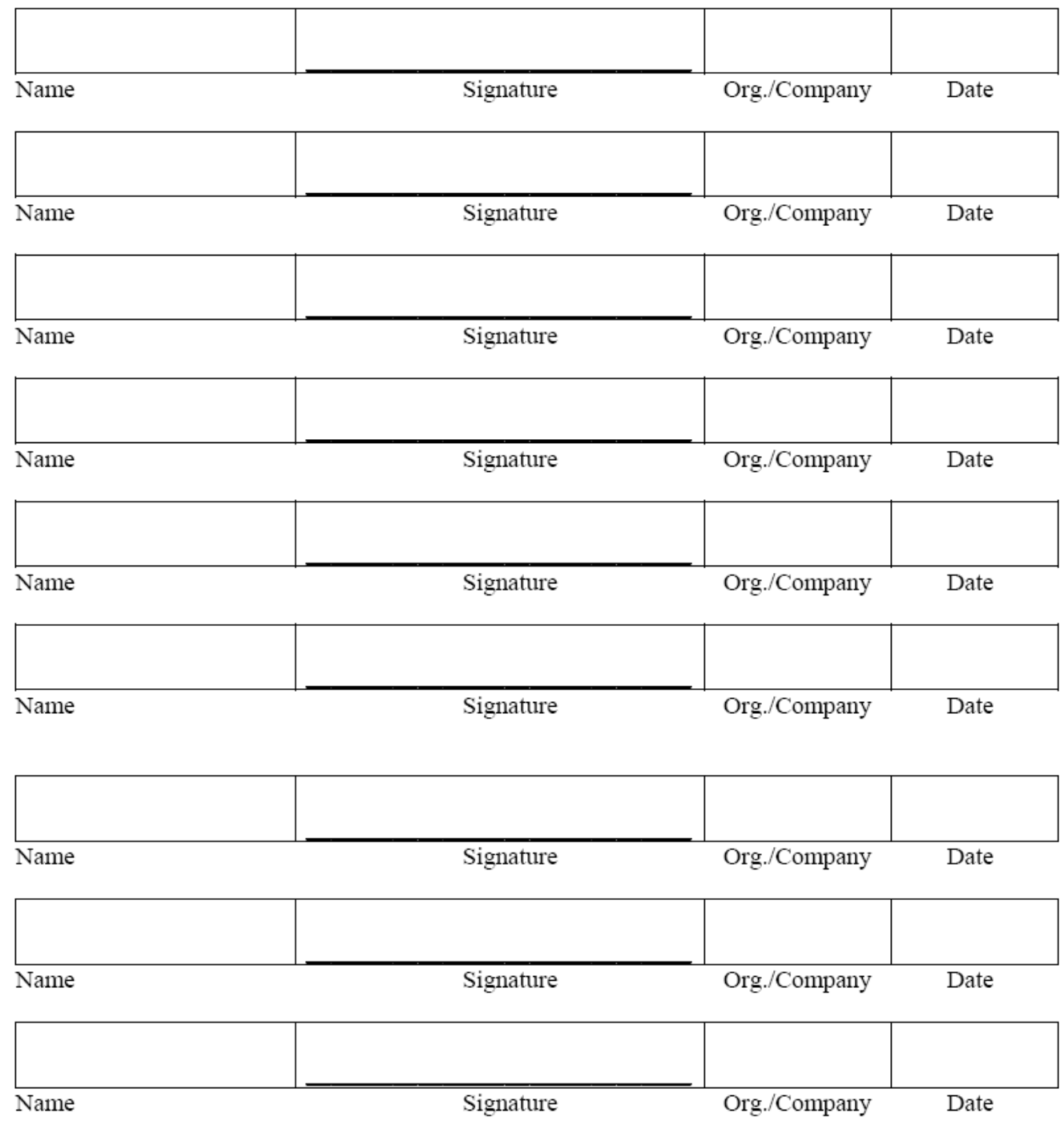




\section{Appendix D - SNL/CA Communication Plan Supplement}




\section{Sandia National Laboratories, California Communication Plan Supplement}

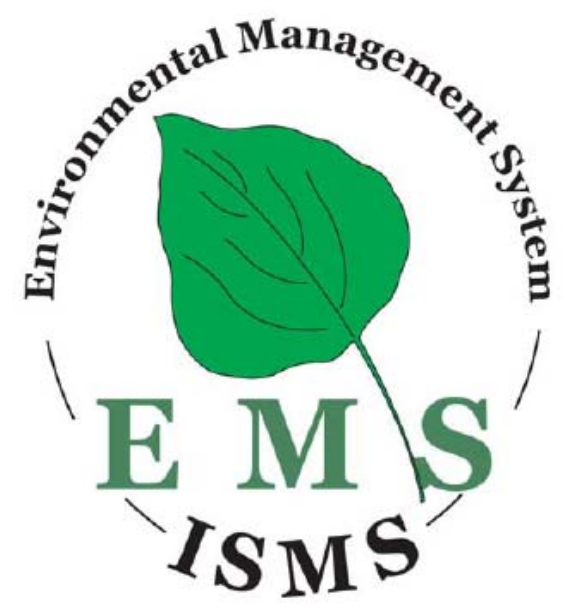

Approval by:

Original approved

Gary Shamber, Manager, 8516

$\underline{3 / 24 / 05}$

SNL/CA Environmental Management Representative

Date

The following provides a description of the additional EMS program communications related elements incorporated at the Sandia National Laboratories, California (SNL/CA) site. 


\section{SNL/CA Communications Staff Elements}

In addition to the corporate staff elements used in the communications of EMS, the CA site has the following:

\section{$1.1 \quad$ Interdisciplinary Team (IDT):}

IDT is a team of subject matter experts in ES\&H, facilities and security who sponsor regular presentations by line on proposed projects and actions. During and following the presentation the IDT determines and communicates environmental requirements and recommendations that will be important for the line to incorporate in their planning and execution of the project or action.

Role as Audience:

- Presentation by line elements on proposed actions or projects that may have ES\&H implications.

Role as Communicator:

- Communicate environmental regulations/requirements so these can be incorporated into the project planning and execution

- Communicate and discuss alternatives to proposed actions that can help support environmental objectives / targets and best business practices.

\subsection{SNL/CA Senior Management EMS Steering Committee}

The EMS Steering Committee consists of the site VP, the Site Operations Director, the site's Environmental Level II and Department Managers and a Line Director

Role as Audience:

- Receive an annual briefing by the site appointed Environmental Management Representative on the status, progress and issues of the EMS

Role as Communicator:

- Provide senior management guidance on site goals and objectives

- Provide site environmental policy execution and standards of performance

- Approve annual site environmental objectives and targets

- Communicate EMS with site senior management

\subsection{SNL/CA EMS Advisory Team}

This team consists of the SNL/CA EMS Core Team and line representatives.

Role as Audience:

- Receive information on site EMS implementation and status

- Receive information on future EMS plans and direction. 
Role as Communicator:

- Communicate line/program issues that may affect EMS application in the line

- Recommend EMS execution actions with the line

- Recommend types of EMS communications that will be most effective

- Provide feedback to the SNL/CA EMS Core Team on EMS execution

\subsection{SNL/CA Environmental Management Representative and SNL/CA EMS Core} Team

This team manages the day to day execution and application of EMS for the CA site. This team is chaired by the site's VP appointed Environmental Management Representative.

Role as Audience:

- Receive and process feedback and recommendations from SNL/CA EMS Advisory Team and SNL/CA EMS Steering Committee

- Receive and process feedback from site surveys and line assessments

- Participate on corporate EMS team

Role as Communicator:

- Provide EMS status and information to SNL/CA EMS Advisory Team and SNL/CA EMS Sr. Mgmt. Steering Committee

- Provide EMS status and information to the site workforce in targeted as well as scheduled briefings and presentations.

- Communicate EMS goals, objectives and targets to site workforce using a variety of communications devices.

- Conduct an annual presentation to the site's Safety, Health and Environmental Advisory Committee (SHEAC).

Note: Because of the size of the site, the differences in management structure/elements and the role of the SNL/CA EMS Core Team, the EMS at SNL/CA will not utilize the SNL/CA ES\&H Coordinators to the extent as those at the $\mathrm{SNL} / \mathrm{NM}$ site.

\section{Communication Tools}

In addition to the corporate tools available for communications the SNL/CA site has the following:

\section{$2.1 \quad$ Publications}

The Communicator - Provides occasional stories about SNL/CA's endeavors in the area of environmental management.

$T N T$ - Timely CNL/CA environmental announcements will be presented on a regular basis. Included will be statistics, reminders to think environmentally, and ways people can incorporate environmentally friendly practices in their daily activities. 
Environmental Scorecard- A quarterly published report to all site managers and members of the workforce that provides a status on environmental objectives and targets.

\subsection{Web Based Communications}

SNL/CA ES\&H web site (Internal) - A comprehensive ES\&H web site that is being modified to provide an environmental Standard of Performance statement from the site VP as well as quick links to corporate and site environmental goals, objectives and targets and other related site.

SNL/CA External 8000 web page - An external website designed for communications to the external community. Will provide links to appropriate corporate environmental web sites and site environmental policies and EMS activities.

\subsection{Other -}

New Hire Orientation Briefings - The new hire briefing will cover an EMS introduction and site environmental policies and activities.

EMS Information for Recruitment - SNL/CA recruiters will be provided with a brochure on the site EMS to give to potential new hires

Annual Site EMS Presentation - Each year the EMS Core Team will sponsor a site wide presentation on environmental issues, progress and challenges.

Environmental Program's Line Implementation Assessments - Each environmental program will conduct a line assessment of its implementation of environmental practices and actions in support of approved site objectives and targets. Program line audits or assessments have been reported by other sites as a highly effective communications exchange. 


\section{SNL/CA Specific EMS Communication Methods}

The table below provides information on unique SNL/CA methods of communicating EMSrelated information and the annual schedule for these actions.

\begin{tabular}{|c|c|c|c|c|}
\hline \multicolumn{5}{|c|}{ SNL/CA EMS Communication Methods } \\
\hline Action & Communicator & Audience & Method & Schedule \\
\hline $\begin{array}{l}\text { Interdisciplinary } \\
\text { Team (IDT) Project } \\
\text { Reviews }\end{array}$ & $\begin{array}{l}\text { Subject Matter } \\
\text { Experts/Members } \\
\text { of IDT }\end{array}$ & $\begin{array}{l}\text { Presenters of } \\
\text { Proposed } \\
\text { Projects }\end{array}$ & $\begin{array}{l}\text { Meeting, } \\
\text { Minutes, SME } \\
\text { written } \\
\text { responses }\end{array}$ & Weekly \\
\hline $\begin{array}{l}\text { "Communicator" } \\
\text { articles }\end{array}$ & EMS Core Team & $\begin{array}{l}\text { Members of } \\
\text { Workforce }\end{array}$ & Publication & Bi-monthly \\
\hline $\begin{array}{l}\text { "Environmental } \\
\text { Scorecard" }\end{array}$ & EMS Core Team & $\begin{array}{l}\text { Members of } \\
\text { Workforce }\end{array}$ & Publication & Quarterly \\
\hline $\begin{array}{l}\text { Annual Site } \\
\text { Environmental } \\
\text { Presentation }\end{array}$ & EMS Core Team & $\begin{array}{l}\text { Members of } \\
\text { Workforce }\end{array}$ & Presentation & July \\
\hline $\begin{array}{l}\text { Annual Site } \\
\text { Environmental } \\
\text { Report }\end{array}$ & EMS Core Team & $\begin{array}{l}\text { External } \\
\text { Community }\end{array}$ & Publication & July \\
\hline Earth Day Activities & EMS Core Team & $\begin{array}{l}\text { Members of } \\
\text { Workforce }\end{array}$ & Various & April \\
\hline $\begin{array}{l}\text { Target } \\
\text { Organizational } \\
\text { Presentations } \\
\end{array}$ & EMS Core Team & $\begin{array}{l}\text { Select Line } \\
\text { Organizations }\end{array}$ & Presentation & Various \\
\hline $\begin{array}{l}\text { Senior Management } \\
\text { Annual Presentation }\end{array}$ & $\begin{array}{l}\text { EMS } \\
\text { Management } \\
\text { Representative } \\
\end{array}$ & $\begin{array}{l}\text { Senior Site } \\
\text { Management }\end{array}$ & Presentation & February \\
\hline $\begin{array}{l}\text { External } 8000 \mathrm{Web} \\
\text { Page }\end{array}$ & EMS Core Team & $\begin{array}{l}\text { External } \\
\text { Community and } \\
\text { Potential Hires }\end{array}$ & Web & Continuous \\
\hline $\begin{array}{l}\text { SNL/CA ES\&H } \\
\text { Web Site }\end{array}$ & EMS Core Team & $\begin{array}{l}\text { Members of } \\
\text { Workforce }\end{array}$ & Web & Continuous \\
\hline $\begin{array}{l}\text { New Hire } \\
\text { Orientation Briefings }\end{array}$ & EMS Core Team & $\begin{array}{l}\text { New Members } \\
\text { of Workforce }\end{array}$ & Presentation & Routine \\
\hline $\begin{array}{l}\text { Contractor EMS } \\
\text { Supplement }\end{array}$ & EMS Core Team & Site Contractors & $\begin{array}{l}\text { Letters / } \\
\text { Brochure }\end{array}$ & Routine \\
\hline $\begin{array}{l}\text { External News } \\
\text { Articles }\end{array}$ & EMS Core Team & $\begin{array}{l}\text { External } \\
\text { Community }\end{array}$ & News Article & Routine \\
\hline $\begin{array}{l}\text { EP Rep Line Visits } \\
\text { and Assessments }\end{array}$ & EP Rep & $\begin{array}{l}\text { Line } \\
\text { Organizations }\end{array}$ & One-on-one & Routine \\
\hline TNT & EMS Core Team & $\begin{array}{l}\text { Members of } \\
\text { Workforce }\end{array}$ & Publication & Varies \\
\hline ENV 233 & EMS Core Team & $\begin{array}{l}\text { Waste } \\
\text { Generators }\end{array}$ & $\begin{array}{l}\text { Classroom } \\
\text { Training }\end{array}$ & Annual \\
\hline $\begin{array}{l}\text { Banners / Posters / } \\
\text { Handouts }\end{array}$ & EMS Core Team & $\begin{array}{l}\text { Members of } \\
\text { Workforce }\end{array}$ & $\begin{array}{l}\text { Misc. } \\
\text { Distribution }\end{array}$ & Routine \\
\hline Recruiting & Recruiters & $\begin{array}{l}\text { Potential New } \\
\text { Hires }\end{array}$ & Brochures & Varies \\
\hline
\end{tabular}




\section{References}

DOE 2005, DOE Order 151.1C, Comprehensive Emergency Management System, November 2, 2005

DOE 2008, DOE Order 450.1A, Environmental Protection Program, June 4, 2008.

ISO 2004, ISO 14001, second edition, Environmental management systems - Requirements with guidance for use, November 15, 2004.

SNL 2007a, CPSR 400.1, Environment, Safety \& Health, January 23, 2007.

SNL 2007b, ES\&H and Emergency Management Administrative Procedure AOP 04-02, revision 3, Requirements Management Process, October 2, 2007.

SNL 2009a, CPR 400.1.1, ES\&H Manual \& Supplements (MN471001), January 9, 2009.

SNL 2009b, CG 100.5, Ensure Quality, April 20, 2009.

SNL 2009c, IM 100, Information Management, April 20, 2009.

SNL 2009d, HR 100.1, Acquire Talent, April 20, 2009.

SNL 2009e, HR 100.2 Develop the Workforce, April 20, 2009.

SNL 2009f, CG 100, Corporate Governance, April 20, 2009.

SNL/CA 2008a, OP471347, Administrative Procedure for Managing Sandia/CA ES\&H Recorded Information, March 19, 2008.

SNL/CA 2008b, Administrative Procedure AP800010, Issue B, Validation of Environmental or EMS-Related Corrective / Preventive Actions, June 4, 2008.

SNL/CA 2008c, Administrative Procedure AP800005, Issue E, Environmental Management System Assessment Process, August 4, 2008.

SNL/CA 2008d, Emergency Management Plan, http://surf.ran.sandia.gov/centers/8500/security/em/pp, September 2008.

SNL/CA 2008e, Administrative Procedure AP800007, Issue C, Receiving, Documenting, and Responding to EMS Communications from External Parties, November 11, 2008. 